ORNL- -6742

DE93 0061;2

ENVIRONMENTAL SCIENCES DIVISION

\title{
BIOFUELS FEEDSTOCK DEVELOPMENT PROGRAM ANNUAL PROGRESS REPORT FOR 1991
}

\author{
L. L. Wright \\ J. H. Cushman \\ A. R. Ehrenshaft ${ }^{1}$ \\ S. B. McLaughlin \\ W. A. McNabb \\ J. W. Ranney \\ G. A. Tuskan \\ A. F. Turhollow ${ }^{2}$
}

${ }^{1}$ Health and Safety Research Division

${ }^{2}$ Energy Division

\section{Environmental Sciences Division}

Publication No. 3890

Date Prepared: July 1992

Date Published: December 1992

Prepared for the

Office of Transportation Technologies

Biofuels Systems Division

EB 2413010

Prepared by the

OAK RIDGE NATIONAL LABORATORY

Oak Ridge, Tennessee 37831-6285

managed by

MARTIN MARIETTA ENERGY SYSTEMS, INC.

for the

U.S. DEPARTMENT OF ENERGY

under contract DE-AC05-84OR21400 
CONTENTS

Page

LIST OF FIGURES $\ldots \ldots \ldots \ldots \ldots \ldots \ldots \ldots \ldots \ldots \ldots \ldots \ldots \ldots \ldots$

LIST OF TABLES $\ldots \ldots \ldots \ldots \ldots \ldots \ldots \ldots \ldots \ldots \ldots \ldots \ldots \ldots \ldots$

ACRONYMS AND INITIALISMS $\ldots \ldots \ldots \ldots \ldots \ldots \ldots \ldots \ldots \ldots \ldots \ldots$

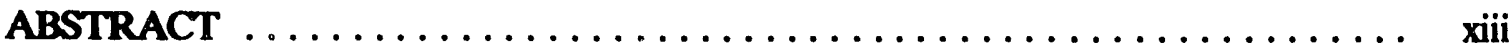

1. INTRODUCTION $\ldots \ldots \ldots \ldots \ldots \ldots \ldots \ldots \ldots \ldots \ldots \ldots \ldots \ldots$

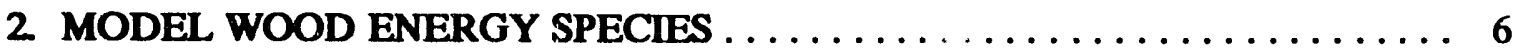

21 AMANA SOCIETY-MONOCULTURE VIABILITY TRIAL

OF WOODY CROPS FOR ENERGY PRODUCTION $\ldots \ldots \ldots \ldots \ldots 7$

22 UNIVERSITY OF GEORGIA-OPTIMIZING ENERGY

YIELDS IN BLACK LOCUST THROUGH GENETIC SELECTION . . . . 10

23 IOWA STATE UNIVERSITY-SELECTION AND BREEDING

OF PEST-RESISTANT CLONES OF POPULUS FOR

BIOMASS ENERGY PRODUCTION IN THE NORTH

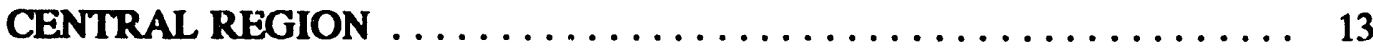

24 MICHIGAN STATE UNIVERSITY-NET ASSIMILATION AND

PHOTOSYNTHATE ALLOCATION OF SRIC POPULUS CLONES . . . . 16

2.5 MISSISSIPPI AGRICULTURAL \& FORESTRY EXPERIMENT

STATION-EARLY SELECTION CRITERIA AND CLONAL

PROPAGATION METHODS FOR INCREASED PRODUCTTVITY

OF SYCAMORE IN SHORT-ROTATION ENERGY SYSTEMS $\ldots \ldots \ldots \quad 18$

2.6 OAK RIDGE NATIONAL LABORATORY-BIOCHEMICAL

AND MOLECULAR BASES OF WATER STRESS

TOLERANCE OF POPLAR $\ldots \ldots \ldots \ldots \ldots \ldots \ldots \ldots \ldots \ldots \ldots \ldots \ldots$

27 SOUTHERN ILLINOIS UNIVERSITY-GENETIC

BIOMASS AND GROWTH ANALYSIS OF CLONAL

SILVER MAPLE (ACER SACCHARINUM L)

IN SEVERAL LOCATIONS $\ldots \ldots \ldots \ldots \ldots \ldots \ldots \ldots \ldots \ldots \ldots \ldots$

28 USDA FOREST SERVICE NORTH CENTRAL FOREST

EXPERIMENT STATION_INCREASING YIELDS OF

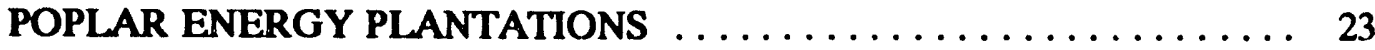

2.9 USDA FOREST SERVICE NORTH CENTRAL FOREST

EXPERIMENT STATION_SHORT-ROTATION WOODY

CROP TRIALS FOR ENERGY PRODUCTION IN

THE NORTH CENTRAL UNITED STATES . . . . . . . . . . . . . 24

210 USDA FOREST SERVICE PACIFIC NORTHWEST

RESEARCH STATION_INCREASING THE

PRODUCTIVITY OF BIOMASS PLANTATIONS OF

ALDER AND COTTONWOOD IN THE PACIFIC NORTHWEST $\ldots \ldots, 26$ 
CONTENTS (Continued)

Page

211 UNIVERSITY OF WASHINGTON-GENETIC

IMPROVEMENT AND EVALUATION OF BLACK

COTTONWOOD FOR SHOR'T-ROTATION BIOMASS

PRODUCTION $\ldots \ldots \ldots \ldots \ldots \ldots \ldots \ldots \ldots \ldots \ldots \ldots \ldots, 29$

3. MODEL HERBACEOUS ENERGY CROPS $\ldots \ldots \ldots \ldots \ldots \ldots \ldots \ldots \ldots$

3.1 AUBURN UNIVERSITY-VARIABILITY FOR BIOMASS

PRODUCTION AND PLANT COMPOSITION IN

SERICEA LESPEDEZA GERM PLASM .................. 33

3.2 AUBURN UNIVERSITY-SELECTION AND

IMPROVEMENT OF HERBACEOUS ENERGY CROPS

FOR THE SOUTHEASTERN USA $\ldots \ldots \ldots \ldots \ldots \ldots \ldots \ldots \ldots, 37$

3.3 UNIVERSITY OF IDAHO-DEVELOPMENT OF

BROADLY ADAPTED CULTIVARS OF WINTER

RAPESEED AS A SOURCE OF DIESEL FUEL $\ldots \ldots \ldots \ldots \ldots \ldots, 38$

3.4 IOWA STATE UNIVERSITY-SELECTION OF

HERBACEOUS ENERGY CROPS FOR PRODUCTION

IN DOUBLE CROPPING SYSTEMS $\ldots \ldots \ldots \ldots \ldots \ldots \ldots \ldots \ldots, 41$

3.5 UNIVERSITY OF KENTUCKY-BIOMASS PRODUCTION

BY FESCUE AND SWTTCHGRASS ALONE AND IN

MIXED SWARDS WITH LEGUME $\ldots \ldots \ldots \ldots \ldots \ldots \ldots \ldots \ldots, 46$

3.6 NORTH DAKOTA STATE UNIVERSITY -EVALUATION

OF HERBACEOUS BIOMASS CROPS IN THE

NORTHERN GREAT PLAINS $\ldots \ldots \ldots \ldots \ldots \ldots \ldots \ldots \ldots \ldots, 48$

3.7 PURDUE UNIVERSTTY-EVALUATION OF POTENTIAL

HERBACEOUS BIOMASS CROPS ON MARGINAL LANDS $\ldots \ldots \ldots, 49$

3.8 VIRGINIA POLYTECHINIC INSTITUTE AND STATE

UNIVERSITY-PERENNIAL SPECIES FOR OPTIMUM

PRODUCTION OF HERBACEOUS BIOMASS IN THE PIEDMONT $\quad . .52$

4. ENVIRONMENTAL RESEARCH AND ANALYSIS $\ldots \ldots \ldots \ldots \ldots \ldots, 54$

4.1 OAK RIDGE NATIONAL LABORATORY-EVALUATING THE

FOR BIOMASS ENERGY CROP PRODUCTION IN

THE UNITED STATES $\ldots \ldots \ldots \ldots \ldots \ldots \ldots \ldots \ldots \ldots \ldots \ldots \ldots$

4.2 OAK RIDGE NATIONAL LABORATORY-ENVIRONMENTAL

EFFECTS OF BIOFUELS FEEDSTOCK PRODUCTION $\ldots \ldots \ldots \ldots, 56$

4.3 OAK RIDGE NATIONAL LABORATORY-BIOMASS ENERGY

STRATEGIES FOR CARBON DIOXIDE MTTIGATION IN

THE UNITED STATES 
CONTENTS (Continued)

Page

5. ECONOMIC ANALYSIS AND INTEGRATION $\ldots \ldots \ldots \ldots \ldots \ldots \ldots .58$

5.1 OAK RIDGE NATIONAL LABORATORY_OPTIMUM NITROGEN NUTRITION IN SHORT-ROTATION SYCAMORE PLANTATIONS . . . 58

5.2 TUSKEGEE UNIVERSITY_BIOMASS RESEARCH AND TRAINING

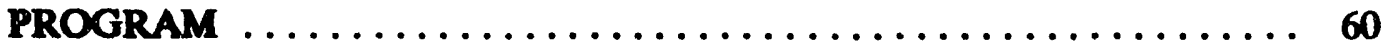

5.3 UNIVERSTTY OF TENNESSEE INSTITUTE OF AGRICULTURE-AN EVALUATION OF GRAIN AND/OR BIOMASS-ORIENTED CROPPING SYSTEMS $\ldots \ldots \ldots \ldots \ldots \ldots \ldots \ldots \ldots \ldots \ldots \ldots \ldots \ldots \ldots$

5.4 UNIVERSTTY OF TENNESSEE INSTITUTE OF AGRICULTURE-AN EVALUATION OF THE HERBACBOUS BIOMASS POTENTIAL IN THE EASTERN UNITED STATES $\ldots \ldots \ldots \ldots \ldots \ldots \ldots \ldots \ldots \ldots \ldots, 63$

5.5 UNIVERSITY OF TENNESSEE INSTTIUTE OF AGRICULTURE-AN EOONOMIC AND TECHNICAL ANALYSIS OF SEIECTED ISSUES REI ATED TO ENERGY CROP PRODUCTION $\ldots \ldots \ldots \ldots \ldots \ldots, 63$

6. TOTAL ENERGY CYCLE ANALYSIS $\ldots \ldots \ldots \ldots \ldots \ldots \ldots \ldots \ldots, 64$

7. DATA AND INFORMATION HANDLING $\ldots \ldots \ldots \ldots \ldots \ldots \ldots \ldots, 65$

8. INTERNATIONAL ENERGY AGENCY ACTIVITTES $\ldots \ldots \ldots \ldots \ldots \ldots 66$ APPENDIX I: CONVERSION FACTORS $\ldots \ldots \ldots \ldots \ldots \ldots \ldots \ldots \ldots \ldots, 67$ APPENDIX II: COMMON AND LATIN NAMES OF WOODY SPECIES $\ldots \ldots 73$ 


\section{LIST OF FIGURES}

Figure

Page

1 Biofuels Feedutock Development Program project locations ............ 2

2 Cumulative 5-year oven-dry yields of two Populus clones grown under woodgrass and wider short-rotation regimes $\ldots \ldots \ldots \ldots \ldots \ldots \ldots . \ldots 28$

3 Trait variation among 11 members of a Popuhus trichocapa

(Pt) $\times$ P. deltoides (Pd) cross, including both diploid and triploid/aneuploid progeny

4 Distribution of sericea lespedexa genotypes for ADF, NDF, and crude protein $\ldots \ldots \ldots \ldots \ldots \ldots \ldots \ldots \ldots \ldots \ldots \ldots \ldots \ldots \ldots \ldots \ldots$

5 Distribution of sericea lespedeza genotypes for lignin, cellubse, hemicellubse, and holocellulose

6 Forty-aix locations of the National Winter Rapeseed Variety Trial ecross the United States during the 1986-1987, 1987-1988, and 1988-1989 growing seasons

7 Average chemical composition of five potential berbaceous energy crops. .................................

81990 yields of dry matter, cellubse, bemicellubse, and lignin for sweet sorghum. $\ldots \ldots \ldots \ldots \ldots \ldots \ldots \ldots \ldots \ldots \ldots \ldots \ldots \ldots . .44$

91990 yields of dry matter, cellulose, hemicellukse, and lignin for sorghum $\times$ sisdangrass.

10 Dry matter yields of nitrogen-fertilized pure stands and legume mixtures with tall fescue 


\section{LST OF TABLES}

Table $\quad$ Page

1 Biofuels Feedatock Development Program projects ............... 3

2 Effects of source of cuttings (from the same clone) on survival of cuttings in May and June 1991 following planting on March 20, 1991, in an outdoor nurzery $\ldots \ldots \ldots \ldots \ldots \ldots \ldots \ldots \ldots \ldots \ldots \ldots \ldots$

3 Maximum biomsas yields of crops grown in Iowa . . . . . . . . . . . 41

4 Mean total biomses yield, grain yield, height, and lodging score of sorghum planted at two aites in $1990 \ldots \ldots \ldots \ldots \ldots \ldots \ldots \ldots$

5 Yields of switchgrass grown in the Virginia Piedmont in 1990 a affected by $\mathbf{N}$ fertilization, date of cutting, or winter-annual legume cover crop $\ldots \ldots \ldots \ldots \ldots \ldots \ldots \ldots \ldots \ldots \ldots$ 


\title{
ACRONYMS AND INITIALISMS
}

\author{
ABA abscisic acid \\ ARS Agricultural Research Service \\ BAP benzo[a]pyrene \\ BFDP Biofuels Feedstock Development Program \\ CRP Conservation Reserve Program \\ DNR Department of Natural Resources \\ DOE Department of Energy \\ EPA Environmental Protection Agency \\ ESD Environmental Sciences Division \\ HEC Herbaceous energy crops \\ IEA International Energy Agency \\ IPM integrated pest management \\ NREL National Renewable Energy Laboratory \\ NRI National Resource Inventory \\ ORNL Oak Ridge National Laboratory \\ PCR polymerase chain reaction \\ R\&D research and development \\ RFLP restriction fragment length polymorphism \\ SRWC short-rotation woody crops \\ USDA U.S. Department of Agriculture \\ US/WSU University of Washington/Washington State University
}




\begin{abstract}
WRIGHT, L. L., J. H. CUSHMAN, A. R. EHRENSHAFT, S. B. MCLAUGHLIN, J. W. RANNEY, G. A. TUSKAN, and A. F. TURHOLLOW. 1992. Biofuels Feedstock Development Program Annual Progress Report for 1991. ORNL-6742. Oak Ridge National Laboratory, Oak Ridge, Tennessee. $93 \mathrm{pp}$.
\end{abstract}

This report provides an overview of the ongoing research funded in 1991 by the Department of Energy's Biofuels Feedstock Development Program (BFDP). The BFDP is managed by the Environmental Sciences Division of the Oak Ridge National Laboratory and encompasses the work formerly funded by the Short Rotation Woody Crops Program and the Herbaceous Energy Crops Program. The combined program includes crop development research on both woody and herbaceous energy crop species, cross-cutting energy and environmental analysis and integration, and information management activities. Brief summaries of 206 different program activities are included in the report. 


\section{INTRODUCTION}

The Biofuels Feedstock Development Program (BFDP) in the Environmental Sciences Division (ESD) at Oak Ridge National Laboratory (ORNL) manages a national program of research on biomass production for the U.S. Department of Energy (DOE). In the past, it has included two programs, the Short Rotation Woody Crops Program (SRWC) and the Herbaceous Energy Crops Program. Both are now managed as a single national program.

BFDP's major sponsor is the Biofuels System Division in DOE's Office of Transportation Technologies. In 1991 the U.S. Environmental Protection Agency (EPA) provided additional support for assessment of biomass energy technologies and the economics of energy crop productions.

The objective of the BFDP is the development of cost-effective production systems for dedicated energy crops. The DOE Biofuel Systems Division emphasizes technologies for producing liquid transportation fuels from lignocellulosic biomass. To complement that research, BFDF is developing wood and grass species, primarily, whose total aboveground biomass can be used as energy feedstock. BFDP's crop development research is closely coordinated with research at the National Renewable Energy Laboratory (NREL) and involves the development of the technologies for converting wood and grass biomass to transportation fuels. BFDP also participates in International Energy Agency (IEA) activities related to woody and herbaceous biomass production.

Research and analysis for BFDP are performed within ESD, in other ORNL divisions, and at cooperating institutions (Fig. 1). In FY 1991 the program supported 2 research projects at ORNL, 15 projects at universities, 4 at U.S. Department of Agriculture (USDA) research stations, 1 at another national laboratory, and 1 at a private company (Table 1). Major efforts included genetic improvement research for woody and herbaceous species; related studies on physiology, nutrient cycling, silviculture, and agronomics; environmental research and analysis; and economic analysis. The genetic improvement, silvicultural, agronomic, and physiologic studies were performed primarily at cooperating institutions, supported by subcontracts and interagency agreements. Supporting studies, including nutrient cycling research and stress physiology, were performed at ORNL. ORNL staff also primarily performed resource and environmental 


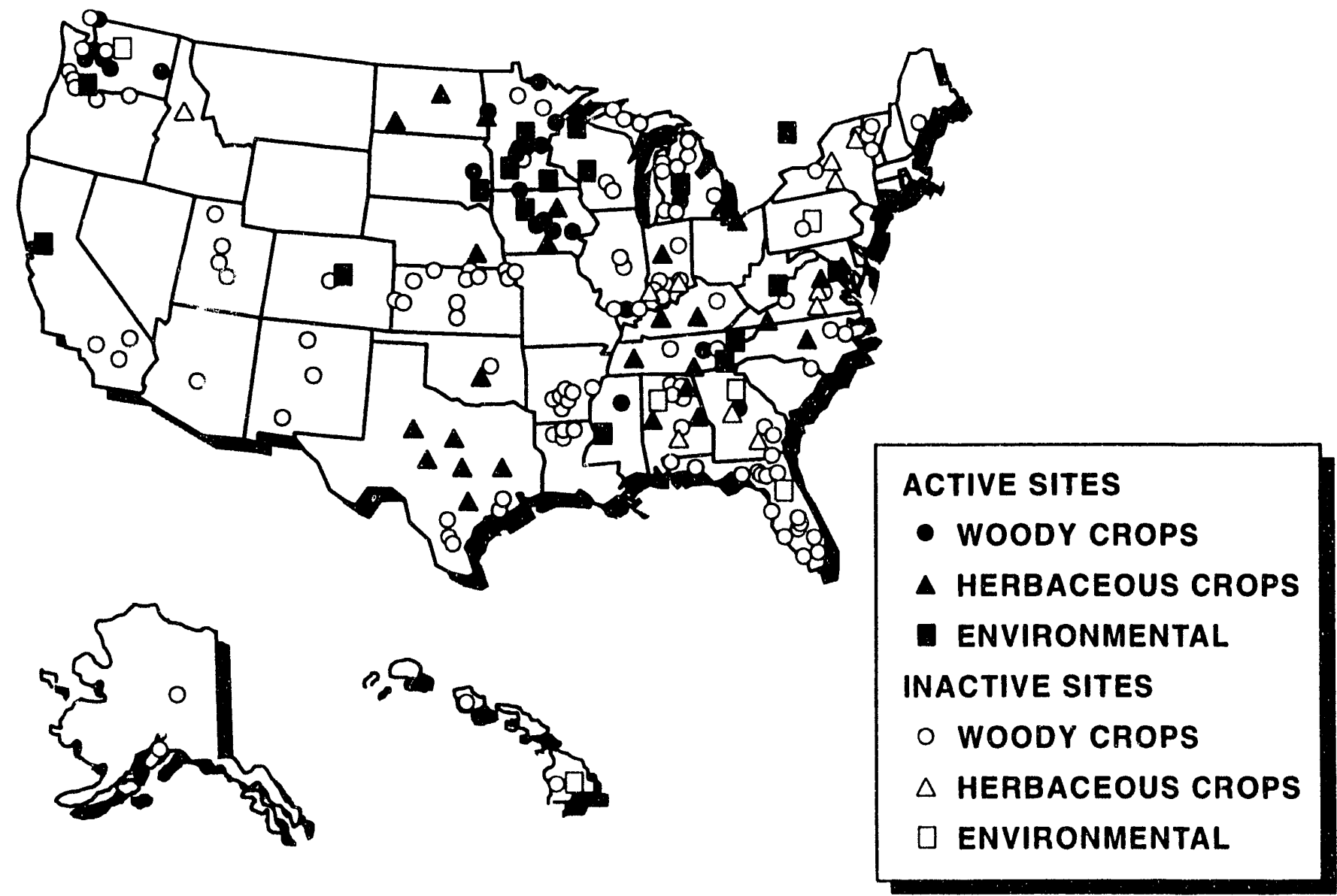

Fig. 1. Biofuels Feedstock Development Program project locations. 
Table 1. Biofuels Feedstock Development Program projects

\begin{tabular}{|c|c|c|}
\hline Institution & Investigator & Title \\
\hline Amana Society" & $\begin{array}{l}\text { L. G. Gnewikow } \\
\text { D. Shoup }\end{array}$ & $\begin{array}{l}\text { Monoculture Viability Trial of } \\
\text { Woody Crops for Energy } \\
\text { Production }\end{array}$ \\
\hline Auburn University & J. A. Mosjidis & $\begin{array}{l}\text { Variability for Biomass } \\
\text { Production and Plant } \\
\text { Composition in Sericea } \\
\text { Lespedeza Germ Plasm }\end{array}$ \\
\hline \multirow[t]{2}{*}{ Auburn University } & D. I. Bransby & $\begin{array}{l}\text { Selection and Improvement of } \\
\text { Herbaceous Energy Crops for } \\
\text { the Southeastern USA }\end{array}$ \\
\hline & & $\begin{array}{l}\text { Biomass Energy Strategies for } \\
\text { Carbon Dioxide Mitigation in the } \\
\text { United States }\end{array}$ \\
\hline Iowa State University & $\begin{array}{l}\text { R. B. Hall } \\
\text { E. R. Hart } \\
\text { H. S. McNabb, Jr. } \\
\text { R. C. Schultz }\end{array}$ & $\begin{array}{l}\text { Selection and Breeding of Pest- } \\
\text { Resistant Clones of Populus for } \\
\text { Biomass Energy Production in } \\
\text { the North Central Region }\end{array}$ \\
\hline Iowa State University & I. C. Anderson & $\begin{array}{l}\text { Selection of Herbaceous Energy } \\
\text { Crops for Production in Double } \\
\text { Cropping Systems }\end{array}$ \\
\hline Michigan State University & $\begin{array}{l}\text { D. I. Dickmann } \\
\text { K. S. Pregitzer }\end{array}$ & $\begin{array}{l}\text { Net Assimilation and } \\
\text { Photosynthate Allocation of } \\
\text { SRIC Populus Clones }\end{array}$ \\
\hline $\begin{array}{l}\text { Mississippi Agricultural \& } \\
\text { For sstry Experiment } \\
\text { Station }\end{array}$ & S. B. Land & $\begin{array}{l}\text { Early Selection Criteria and } \\
\text { Clonal Propagation Methods for } \\
\text { Increased Productivity of } \\
\text { Sycamore in Short-Rotation } \\
\text { Energy Systems }\end{array}$ \\
\hline $\begin{array}{l}\text { North Dakota State } \\
\text { University }\end{array}$ & $\begin{array}{l}\text { D. W. Meyer, } \\
\text { D. O. Erickson, and } \\
\text { R. G. Johnson }\end{array}$ & $\begin{array}{l}\text { Evaluation of Herbaceous } \\
\text { Biomass Crops in the Northern } \\
\text { Great Plains }\end{array}$ \\
\hline Purdue University & K. D. Johnson & $\begin{array}{l}\text { Evaluation of Potential } \\
\text { Herbaceous Biomass Crops on } \\
\text { Marginal Lands }\end{array}$ \\
\hline $\begin{array}{l}\text { Oak Ridge National } \\
\text { Laboratory }\end{array}$ & $\begin{array}{l}\text { H. Van Miegroet } \\
\text { R. J. Norby }\end{array}$ & $\begin{array}{l}\text { Optimum Nitrogen Nutrition in } \\
\text { Short-Rotation Sycamore } \\
\text { Plantations }\end{array}$ \\
\hline
\end{tabular}


Table 1 (Continued)

\begin{tabular}{|c|c|c|}
\hline Institution & Investigator & Title \\
\hline $\begin{array}{l}\text { Oak Ridge National } \\
\text { Laboratory }\end{array}$ & $\begin{array}{l}\text { J. W. Ranney } \\
\text { L. L. Wright }\end{array}$ & $\begin{array}{l}\text { Environmental Policy and Effects } \\
\text { of Biofuels Feedstock Production }\end{array}$ \\
\hline $\begin{array}{l}\text { Oak Ridge National } \\
\text { Laboratory }\end{array}$ & R. L. Graham & $\begin{array}{l}\text { Land Base Evaluation for } \\
\text { Biomass Energy Crop Production } \\
\text { in the United States }\end{array}$ \\
\hline $\begin{array}{l}\text { Oak Ridge National } \\
\text { Laboratory }\end{array}$ & T. J. Tschaplinski & $\begin{array}{l}\text { Biochemical and Molccular Bases } \\
\text { of Water Stress Tolerance of } \\
\text { Poplar }\end{array}$ \\
\hline Southern Illinois University & $\begin{array}{l}\text { W. C. Ashby } \\
\text { J. E. Preece } \\
\text { i. L. Roth }\end{array}$ & $\begin{array}{l}\text { Genetic Biomass and Growth } \\
\text { Analysis of Clonal Silver Maple } \\
\text { (Acer saccharinum L.) in Several } \\
\text { Locations }\end{array}$ \\
\hline Tuskegee University & A. Weaver & $\begin{array}{l}\text { Biomass Research and Training } \\
\text { Program }\end{array}$ \\
\hline $\begin{array}{l}\text { University of Tennessee } \\
\text { Institute of Agriculture }\end{array}$ & B. C. English & $\begin{array}{l}\text { An Evaluation of Grain and/or } \\
\text { Biomass-Oriented Cropping } \\
\text { Systems }\end{array}$ \\
\hline $\begin{array}{l}\text { University of Tennessee } \\
\text { Institute of Agriculture }\end{array}$ & B. C. English & $\begin{array}{l}\text { An Evaluation of the } \\
\text { Herbaceous Biomass Potential in } \\
\text { the Eastern United States }\end{array}$ \\
\hline $\begin{array}{l}\text { University of Tennessee } \\
\text { Institute of Agriculture }\end{array}$ & B. C. English & $\begin{array}{l}\text { An Economic and Technical } \\
\text { Analysis of Selected Issues } \\
\text { Related to Energy Crop } \\
\text { Production }\end{array}$ \\
\hline University of Idaho & $\begin{array}{l}\text { D. L. Auld } \\
\text { K. A. Mahler }\end{array}$ & $\begin{array}{l}\text { Development of Broadly } \\
\text { Adapted Cultivars of Winter } \\
\text { Rapeseed as a Source of Diesel } \\
\text { Fuel }\end{array}$ \\
\hline University of Kentucky & M. Collins & $\begin{array}{l}\text { Biomass Production by Fescue } \\
\text { and Switchgrass Alone and in } \\
\text { Mixed Swards with Legume }\end{array}$ \\
\hline University of Washington & $\begin{array}{l}\text { R. F. Stettler, } \\
\text { P. E. Heilman, T. } \\
\text { M. Hinckley, and } \\
\text { H. D. Bradshaw, Jr. }\end{array}$ & $\begin{array}{l}\text { Genetic Improvement and } \\
\text { Evaluation of Black Cottonwood } \\
\text { for Short-Rotation Biomass } \\
\text { Production }\end{array}$ \\
\hline
\end{tabular}


Table 1 (Continued)

\begin{tabular}{|c|c|c|}
\hline Institution & Investigator & Title \\
\hline University of Georgia & $\begin{array}{l}\text { B. C. Bongarten } \\
\text { L. R. Boring } \\
\text { R. O. Teskey }\end{array}$ & $\begin{array}{l}\text { Optimizing Energy Yields in } \\
\text { Black Locust Through Genetic } \\
\text { Selection }\end{array}$ \\
\hline $\begin{array}{l}\text { USDA Forest Service North } \\
\text { Central Forest Experiment } \\
\text { Station }\end{array}$ & J. G. Isebrands & $\begin{array}{l}\text { Increasing Yields of Poplar } \\
\text { Energy Plantations }\end{array}$ \\
\hline $\begin{array}{l}\text { USDA Forest Service North } \\
\text { Central Forest Experiment } \\
\text { Station }\end{array}$ & E. A. Hansen & $\begin{array}{l}\text { Short-Rotation Woody Crop } \\
\text { Trials for Energy Production in } \\
\text { the North Central United States }\end{array}$ \\
\hline $\begin{array}{l}\text { USDA Forest Service Pacific } \\
\text { Northwest Research Station }\end{array}$ & D. S. DeBell & $\begin{array}{l}\text { Increasing the Productivity of } \\
\text { Biomass Plantations of Alder and } \\
\text { Cottonwood in the Pacific } \\
\text { Northwest }\end{array}$ \\
\hline $\begin{array}{l}\text { Virginia Polytechnic Institute } \\
\text { and State University }\end{array}$ & $\begin{array}{l}\text { D. J. Parrish, } \\
\text { D. D. Wolf, } \\
\text { W. L. Daniels, } \\
\text { J. S. Cundiff, } \\
\text { and D. H. Vaughan }\end{array}$ & $\begin{array}{l}\text { Perennial Species for Optimum } \\
\text { Production of Herbaceous } \\
\text { Biomass in the Piedmont }\end{array}$ \\
\hline
\end{tabular}

${ }^{a}$ Other institutions cost sharing the Amana Society contract include Iowa State University, the Iowa Department of Natural Resources (DNR) Energy and Geological Resources Division, and the Iowa DNR Forestry Division. 
assessment, studies on $\mathrm{CO}_{2}$ cycling in biomass-based energy systems, and economic analysis.

In FY 1991, BFDP had four major research components: Model Wood Energy Crops, Model Herbaceous Energy Crops, Environmental Research and Analysis, and Economic Analysis and Integration. Other program efforts included IEA activities, Data and Information Handling, and Total Energy Cycle Analysis. The current status of each of these areas is described briefly in the following sections.

\section{MODEL WOOD ENERGY SPECIES}

The goal of the Model Wood Energy Crops umponen: is to develop wood energy crops for U.S. regions where land availability and climate are favorable the establishment of biomass-based energy systems. Model species have been selected based on their potential to be highly productive on a broad range of sites under environmentally sound management practices.

The primary area of research under this element is the improvement of Populus species and hybrids. Populus research subcontracts have been strategically placed within the United States based on the natural range for each species and potential productivity levels within the region. Activities currently include regional interactive Populus breeding programs ir the north central arid Pacific Northwest regions. In the north central region, efforts are continuing on the development of early selection procedures for resistance to Septoria canker and cottonwood leaf beetle. In the Pacific Northwest region, first-year efforts on the development of a Populus molecular map have been completed. In other regions, an initial version of a Populus growth model (ECOPHYS) has been validated. First-year field testing of herbicide-tolerant poplars has been completed. In addition, a final report on the evaluation of the "woodgrass" culture system has been completed; the report condudes that wider spacings favor cumulative biomass yields over time over that achievable under woodgrass systems.

Other model species include silver maple, sycamore, and black locust. Using material propagated in a tissue culture, a silver maple seed sources study was established at two locations in southern Illinois. Three additional locations are scheduled for establishment in 1992. Research has continued on developing effective clonal propagation 
techniques, improving rooting success, and improving breeding and genetic selection techniques for sycamore. Staff continued research on black locust, particularly in connection with improvements in productivity, nitrogen fixation, and pest resistance. Genetic transformation techniques have also been investigated for black locust. Brief highlights of subcontracted work on woody species follow.

\subsection{AMANA SOCIETY-MONOCULTURE VIABILITY TRIAL OF WOODY CROPS FOR ENERGY PRODUCTION}

Investigators: D. A. Shoup and L. Gnewikow, Amana Society; J. Colletti, Iowa State University; R. Hall, Iowa State University; R. Schultz, Iowa State University

Goaks

Through a commercial-scale monoculture viability trial of silver maple (Acer saccharinum L.), to generate accurate information on plantation cost and biomass yields and to identify the risk factors associated with growing a single tree species.

\section{Highlights}

The following items occurred during the period October 1, 1990 through September 30, 1991 (FY 1991).

In early April 1991, we lifted and graded approximately 22,000 silver maple seedlings. The majority of seedlings were $2-0$ stock $(20,200)$, and the balance was 1-0 stock. All of these seedlings were to be planted in Unit 2 (5.7 ha). Starting in early April and continuing into early July, the entire project site was flooded. Similar to the flooding that occurred in 1990, this flood event was a so-called "100-year flood." Unlike the flood of 1990, however, this flooding was continuous from April through early July. Thus, all planting, cultural, and research activities planned for the three units were altered or postponed. Unit 2 was prepared during the previous fall of 1990 for spring of 1991 planting. We postponed this planting until the fall of 1991. Unit 2 has been mowed and will be treated with postemergent and preemergent herbicides prior to fall planting. Another 24,000 silver maple seedlings (2-0 stock) were ordered from the Iowa DNR State Forest Nursery for the fall planting.

The originally scheduled replanting of a portion of Unit 1 was postponed until spring of 1992. Also postponed was the reestablishment of a scaled-down Nelder spacing- 
rotation-fertilizer study in Unit 1 and the planting of Dr. Ed Hansen's Populus spp. clonal trial. We now plan to plant four clones of cottonwood and hybrid Populus (cottonwood clone IS-31, and hybrids NC-5326, NC-5328, and W-5), totaling 1000 individuals in Unit 1 in the spring of 1992 . The integrated pest management (IPM) plan developed and installed 2 years ago was to be applied again this year at regular intervals throughout the 1991 growing season. A trained individual from $i$ mana was to apply the IPM monitoring plan. Based on two monitoring times, the IPM data indicated no problems in terms of pests, as evaluated by the Iowa State University IPM specialists (Drs. Hart and McNabb). During mid-July of 1991, 20 inventory plots were taken in Unit 3 to establish the percentage of seedling survival and to investigate the pattern of survival as related to site variables such as elevation. The mean survival percentage was $56 \%$. The mean percentage for dead and missing seedlings was $44 \%$ with a standard deviation of the sample of $19 \%$. Just prior to the end of FY 1991, another sampling of survival of seedlings in Units 1 and 3 was done. Twenty inventory plots were surveyed in each unit in a manner identical to the survey taken in Unit 3 in July 1991 . There was no change in the mean survival percentage in Unit 3, vith survival at $57 \%$. The difference is explained in terms of sampling error. Survival in Unit 1 was less, relative to Unit 3. Survival in Unit 1 was $49 \%$; the higher survival values seemingly were associated with areas planted in the spring of 1989 rather than in the fall of 1988 . The only plantation cultural activity undertaken during the remaining portion of the 1991 growing season was mowing of Units 1 and 3. We plan to arrange for the application of a "Weed Badger" mechanical cultivator to remove and control the between-tree weed competition within the rows. This mechanical within-row cultivation, along with close between-row mowing will take place in Units 1 and 3. Late-season postemergent herbicide treatment will be done on portions of Units 1 and 3 where the heaviest weed competition exists.

Initial discussions occurred with farm management at Amana to explore another site farther upstream away from the flood pool of Coralville Reservoir and out of the 1to 5-year flood plain zone (a slightly more elevated terrace on the Iowa river). One particular site may be suitable, but its availability was unclear, and the time frame within which such a decision could be made was unknown.

There were three different presentations about the project to various audiences. A poster and abstract was presented at the second Leopold Center for Sustainable 
Agriculture Conference held in January of 1991 in Ames. A paper dealing with an economic analysis of the Amana SRWC production system was presented at the 1991 Southern Biomass Conference in January of 1991. Finally, a revised poster of the project was created and presented at the 1991 DOE Contractors meeting held at Davis, California, in mid-September of 1991.

\section{Information Dissemination}

Colletti, J., L. Gnewikow, R. Faltonson, A. Skadberg, D. Schultz, and R. Hall. 1991. A Monoculture Viability Trial of Woody Crops for Energy Production-Annual Report for the period March 1, 1989, through December 31, 1990. U.S. DOE Subcontract 19X-SB106C Submitted January 1, 1991. 116 pp.

Twarok, C. J., and J. P. Colletti. 1991. Economics of a short-rotation woody crops plantation at Amana, Iowa. Paper presented at the 1991 Southern Biomass Conference. January 7-10, 1991, Baton Rouge, La.

Gan, J., J. P. Colletti, and C. J. Twarok, 1991. An economic analysis of short-rotation woody crops production in Amana, Iowa. Unpublished manuscript. In preparation for submission to a refereed journal.

Bahr, G. L. 1991. Rainfall simulations using common tracers to test solute movement within a fluvent soil. Unpublished Masters of Science Thesis. Iowa State University, Ames. 23 pp.

\section{Abstract and Poster Presentations}

J. P. Colletti, R. B. Hall, and R. C. Schultz, 1991. The Amana Project: Linking Agriculture and Forestry Through Sustainable Biomass Production. Poster presented at the Second Leopold Center for Sustainable Agriculture Conferences entitled "New Developments in Cropping Systems and Livestock Management Systems," February 11-12, 1991, Scheman Building, Iowa State University, Ames.

J. Colletti, L. Gnewikow, R. Hall, and R. Schultz, 1991. The Amana Project. Poster presented at the 1991 DOE Contractors Meeting. September 16-20, 1991. Davis, California. 


\title{
2.2 UNIVERSITY OF GEORGLA-OPTIMIZING ENERGY YIELDS IN BLACK LOCUST THROUGH GENETIC SELECTTON
}

\author{
Investigators: B. Bongarten, L. Borins, and R. Teskey
}

\section{Goak}

To determine efficient strategies for selecting and breeding black locust (Robinia psuedoacacia) for increased energy yield and to estimate the increase in energy yield resulting from the implementation of such programs.

\section{Highlights}

For FY 1991, the principal activities in this project were: (1) estimation of black locust biomass yields in the Georgia Piedmont following genetic improvement and alternative management practices, (2) refinement of techniques for vegetative reproduction of black locust via greenwood stem cuttings, (3) development of gene transfer technology in black locust, (4) determination of morphological traits useful for verification of clonal identity in the field, and (5) collection of nursery data to be used for development of models maximizing genetic nursery-rotation age correlations. Results and status of work are as follows.

Growth of black locust after three field seasons in the Georgia Piedmont was assessed. During this period growth was rapid, comparing favorably with hybrid poplars grown in other parts of the world. However, current annual increment was beginning to decline in plots with the largest trees by the third year, suggesting that the optimal rotation length for black locust on these sites might be around 4 years. Irrigation increased biomass production by about $50 \%$. Nitrogen fertilization also increased biomass production, although by modest amounts $(12 \%)$ in this nitrogen-fixing species. The effects of irrigation and nitrogen fertilization on biomass production were additive. Neither irrigation nor nitrogen fertilization influenced tree survival. Family differences in biomass production were large, and family rankings for biomass production were uninfluenced by irrigation, nitrogen, or block effects. From family selection alone, biomass productivity can be increased by more than $50 \%$. Greater gains are possible from individual tree selection and vegetative propagation. Block differences in biomass yield were equally large and appear to confirm numerous anecdotal reports that black locust growth is greatly adversely affected where soil moisture, aeration, and rootable depth are limited. Through 3 years of 
growth, biomass production of selected black locust families in the Piedmont of the southeastern United States is projected to range from about 8 :o $4 \mathrm{Mg} \mathrm{ha}^{-1}$ year $^{-1}$, depending on site and cultural conditions.

Techniques for vegetatively reproducing black locust via greenwood stem cuttings were refined in FY 1991. It now appears possible to establish large clonal trials with propagules generated from such material. Success depends on using vigorous shoots, about 4 weeks of age and a porous, well-aerated rooting medium. Control of insects and diseases on stock plants is also essential. A 5-s basal dip in IBA (@ 8000 to 16,000 ppm) dissolved in ethanol enhances rooting. More than $85 \%$ of harvested cuttings can be rooted within 4 weeks in the majority of clones when these practices are used.

In FY 1991 additional emphasis was placed on developing gene transfer technologies for black locust. The applied objective of this work is to introduce genes for resistance to two major insect pests of black locust-the stem borer and leaf miner. Work we conducted in previous years revealed that some lines of black locust were capable of somatic embryogenesis, thus providing a means for propagating genetically transformed embryos. This year, a search for addition lines capable of somatic embryogenesis was conducted. However, only one of over 600 cultures exhibited somatic embryogenesis. Drug selection sensitivity tests were also conducted to determine which marker genes and drugs would be most suitable for identifying transformed cells. These tests revealed that kanamycin resistance is probably not the selective marker of choice because relatively high levels of kanamycin are required to suppress the growth of black locust proembryogenic masses. Geneticin or hygromycin resistance show greater promise because the growth of proembryogenic masses of black locust are suppressed at low levels of these drugs.

Several morphological and phenological markers were discovered that permit the unambiguous field identification of the clones in our program. This capability is a necessary prelude to the establishment of large clonal trials in which chemical verification is too costly and time consuming. Morphological markers include leaf, twig, and form traits. More than 20 environmentally stable traits were found to vary among clones, permitting the differentiation of over 1 million clones.

Seedlings of the families represented in our field progeny test were grown in the nursery. These trees will be measured for numerous morphological, anatomical, and phenological traits that are to be incorporated in models to predict biomass productivity at 
rotation age. Prediction models will also incorporate seed, growth analysis, and root growth data, which have already been collected. Seedlings grown in the nursery this year will also be used to establish a progeny test in eastern Kansas, in cooperation with Wayne Geyer at Kansas State University.

\section{Information Dissemination}

Bongarten, B. C., S. A. Merkle, and J. W. Hanover. 1991. Genetically improved black locust for biomass production in short-rotation plantations. IN (D. Klass, ed.) IGT Symposium on Energy from Biomass and Wastes, XV. In press.

Bongarten, B. C., D. A. Huber, and D. K. Apsley. Environmental and genetic influences on short-rotation biomass production of black locust (Robinia pseudoacacia $\mathrm{L}_{\text {.) }}$ ) in the Georgia Piedmont. For. Ecol. Mangage. In review.

Johnsen, K. H., B. C. Bongarten, and L. R. Boring. 1991. Effects of nitrate on in vivo nitrate reductase activity of seedlings from three open-pollinated families of Robinia pseudoacacia. Tree Physiol. 8:381-389.

Johnsen, K. H., and B. C. Bongarten. 1991. Allometry of acetylene reduction and nodule growth of Robinia pseudoacacia families subjected to varied root zone nitrate concentrations. Tree Physiol. In press.

Johnsen, K. H., and D. K. Apsley. 1991. A simple method to measure acetylene reduction of intact, nodulated tree seedlings. Tree Physiol. In press.

Bongarten, B. C. Genetic structure of black locust in its native range. IN (J. W. Hanover, ed.) Black locust: Biology, culture and utilization. In review.

Johnsen, K. H., and B. C. Bongarten. Effects of nitrate on nitrogen fixation and growth of Robinia pseudoacacia seedlings: A functional growth analysis approach using ${ }^{i 5}$ N. Physiol. Plant. In review.

\section{Presentations}

Bongarten, B. C. Below-ground root research: Root microbial interactions. Biofuels Energy Conference. Davis, Calif., Sept. 16-20, 1991.

Bongarten, B. C., S. A. Merkle, and J. W. Hanover. Genetically improved black locust for biomass production in short-rotation plantations. IGT Symposium on Energy from Biomass and Wastes, XV. Washington, D.C., March 25-29, 1991. 
Bongarten, B. C. Genetic structure of black locust in its native range. International Conference on Black Locust: Biology, Culture, and Utilization. East Lansing, Mich., June 17-21, 1991.

Merkle, S. A. Somatic embryogenesis of black locust. International Conference on Black Locust: Biology, Culture, and Utilization. East Lansing, Mich., June 17-21, 1991.

Bongarten, B. C. Biomass yields from black locust in the Georgia Piedmont after two field seasons. Southern Biomass Energy Conference. Baton Rouge, La., Jan. 7-10, 1991.

\subsection{IOWA STATE UNIVERSITY-SELECTION AND BREEDING OF PEST- RESISTANT CLONES OF POPULUS FOR BIOMASS ENERGY PRODUCTION IN THE NORTH CENTRAL REGION}

Investigators: R. Hall, E. R. Hart, S. McNabb, Jr., and R. Schultz

Goals

To develop new clones of Populus for use in the production of biomass energy in the North Central Region of the United States.

\section{Highlights}

By 1990 , we had assembled and tested over 500 clones of existing materials. Since 1990, we have added 92 new clones and 90 new families of $P$. deltoides, 77 new families of Leuce section hybrids, 4 families of $P$. nigra, and 8 families of $P$. trichocarpa and its hybrids. New progeny and clones are screened for resistance to three leaf diseases (Melampsora rust, Septoria leaf spot, and Marssonina) and growth rates in an initial nursery cycle over at least 2 years. Seventy-one Populus clones are in the 1991 secondyear nursery cycle. Leaf disease screening was done on all first- and second-year nursery entries three times during the 1991 growing season. Survivors of this initial selection undergo a second screening cycle that is primarily for Septoria canker and ease of propagation. Ten clones were planted in the Septoria screening trial this year. The clones that pass both levels of screening are increased and distributed within the region for field testing under local environmental and cultural conditions. We prepared the first two clones for such release in 1991. Forty-two of the currently most promising Populus clones were planted in an advancement bed for the purpose of vegetative material 
increase and additional clonal observation. Approximately 30 clones will be available for release to field testing in 1992.

Screening for resistance to the major defoliating insect pest, the cottonwood leaf beetle, is also a major component of this project. A set of procedures has been developed for efficiently screening the large numbers of clones we have in our nursery trials. Weekly observations were made in 1991. Five complete and one partial generation of leaf beetle feeding damage was recorded. More-detailed screening techniques are then used on the most important/informative clones. Laboratory screening of 31 clones has been completed, and several were shown to differ significantly in their effects on beetle developmental biology. A shoot- and stem-boring lepidopteran responsible for much early-season shoot damage in second-year plantings has been identified tentatively as the cottonwood twig borer, Gypsonoma haimbachiana (Kearfott). Additional stem-borer damage that occurs in the fall has very tentatively been attributed to the European corn borer, Ostrinia nubilalis (HBN.). All nursery and field validation selections are being surveyed for susceptibility to both of these stem-borer problems.

Supporting research is being done to establish correlations between laboratory, nursery, and field performance. In 1991, 27 clones were planted in this test. Unfortunately, a prolonged spring flood destroyed enough of this planting to require its replacement in 1992. Another study was initiated to determine the impact of defoliation on biomass production. Four clones were planted for the study and three series of defoliations were carried out in 1991. Observations after the first two defoliations have shown that some trees respond to higher levels of defoliation with more lateral branching. Resistance mechanisms are being studied by using Populus plants transformed with a proteinase inhibitor. Greenhouse and preliminary field studies with a clone containing the nos and pin 2 promoters have indicated that the nos regulator promotes expression in root, stem, and leaf tissues. The petiole tissue of the leaf appears to exhibit the highest gene expression. Transformed lines were shown to reduce leaf beetle fecundity and development rates. Both in vitro and in vivo materials are being prepared for testing the place of proteinases in the host-pathogen interaction of susceptible and resistance hosts for Septoria musiva and Melampsora medusae pathogens. All of this basic information will be used to improve our overall approach to the breeding and selection work. 


\section{INFORMATION DISSEMINATION}

Hart, E. R., R. B. Hall, and R. D. Hanna. 1991. Dispersal of Fenusa dohrnii

(Hymenoptera: Tenthredinidae) from an Alnus short-rotation forest plantation. Great Lakes Entomol. 24: 63-68.

Hart, E. R., D. G. Petty, R. B. Hall, D. A. Herms, R. D. Hanna, and J. N. Kean. 1991. Activity of Fenusa dohmii (Hymenoptera: Tenthredinidae) in the north-central United States. Environ. Entomol. 20: 534-539.

Klopfenstein, N. B., N.-Q. Shi, A. Kernan, H. S. McNabb, Jr., R. B. Hall, E. R. Hart, and R. W. Thornburg. 1991. Transgenic Populus hybrid expresses a wound-inducible potato proteinase inhibitor II-CAT gene fusion. Can. J. For. Res. 21 (9): 1321-1328.

Allen, K. K., E. R. Hart, R. B. Hall, N. B. Klopfenstein, S. A. Heuchelin, H. S. McNabb, Jr., and R. W. Thornburg. 1991. Evaluating impact of genetically transformed Populus on the developmental biology of the imported willow leaf beetle. Presentation to North American Forest Insect Work Conference.

Bingaman, B.R. 1991. Leaf age heterogeneity among selected Populus clones:

1. Influences on feeding and oviposition preferences of adult Chrysomela scripta F. (Coleoptera:Chrysomelidae). 2. Correlations of preferences with foliar phenolic glycoside profiles. Ph.D. Dissertation. Iowa State University, Ames.

Colletti, J., L. Rule, A. Skadberg, D. Schultz, C. Mize, R. Hall, and P. Wray. 1991. Agroforestry systems for the midwest. Ames For. 78: 10-13.

Colletti, J., C. Mize, D. Schultz, L. Rule, A. Skadberg, R. Hall, and P. Wray. 1991. Land application of sludge to forest and herbaceous energy crops. Ames For. 78: 24-30.

Klopfenstein, Ned B., Harold S. McNabb, Jr., Richard B. Hall, Elwood R. Hart, and Robert W. Thornburg. 1991. Potential of heterologous promoters to regulate expression of plant defense gene constructs in transgenic hybrid poplar. (Abstr.) International Symposium on the Applications of Biotechnology to Tree Culture, Protection and Utilization. August 5-8, 1991. Columbus, Ohio.

Luley, C. J. and H. S. McNabb, Jr. 1991. Estimation of seasonal ascospore production of Mycosphaerella populorum. Can. J. For. Res. ?1 (9): 1349-1353. 
McNabb, H. S., Jr., N. B. Klopfenstein, R. D. Hanna, R. B. Hall, E. R. Hart, S. A. Heuchelin, and R. W. Thornburg. 1991. A field trial of transgenic hybrid poplar trees: Establishment and growth through the second season. pp. 155-9. IN: D. R. MacKenzie and Suzanne C. Henry (eds.), Biological Monitoring of Genetically Engineered Plants and Microbes. (Proc. International Conference on The Biosafety Results of Field Tests of Genetically Modified Plants and Microorganisms, Kiawah Island, S.C., Nov. 27-30, 1990.) Agricultural Research Institute, Bethesda, Md, USA.

McNabb, H. S., Jr., E. R. Hart and R. B. Hall. 1991. Disease and insect resistance: A key to successful short rotation woody crops systems. Ames For. 78: 31-33. McNabb, H. S., Jr., E. R. Hart, R. B. Hall, N. B. Klopfenstein, S. A. Heuchelin, K. K. Allen, and R. W. Thornburg. 1991. Use of the proteinase inhibitor II gene for increased pest resistance in poplars. Presentation to North American Forest Insect Work Conference.

\section{MICHIGAN STATE UNIVERSITY-NET ASSIMILATION AND PHOTOSYNTHATE ALLOCATION OF SRWC POPULUS CLON AS}

Investigators: D. Dickmann, K. Pregitzer

Goak

To provide a physiological basis for increasing short-rotation yields in Populus.

\section{Highlights}

Hybrid Populus clones Tristis and Eugenei were subjected to varied combinations of soil water and nitrogen $(\mathrm{N})$ levels in a greenhouse study designed to follow up the original Experiment No. 2. Gas exchange, water relations, and involvement of abscisic acid (ABA) were examined. Tristis and Eugenei clones maintained comparable photosynthesis and stomatal conductance during the initial days of a flooding treatment, compared with nonflooded plants. As flooding lengthened, significant declines in diurnal photosynthesis and conductance occurred. However, the declines were partially compensated by the addition of $\mathrm{N}$ and the emergence of adventitious rooting around the submerged portions of the stem, suggesting that both clones are somewhat flood resistant. Flooding did not induce substantial changes in leaf ABA concentrations, indicating that 
the physiological changes induced by flooding were not associated with $\mathrm{ABA}$. Under minimum water stress, additions of $\mathbf{N}$ to the soil increased photosynthesis, leaf chlorophyll, and $\mathbf{N}$ content. As soil progressively dried, however, high- $\mathbf{N}$ treated plants showed drastic decreases of photosynthesis and stomatal conductance. Drought induced substantial accumulation of $A B A$ in the leaves, which was associated with the observed physiological changes. Nitrogen caused additional ABA accumulation beyond what was induced by drought alone. The experience of one drought period substantially reduced the accumulation of $\mathrm{ABA}$ when a second drought followed a period of stress interruption. Photosynthesis, conductance, and internal $\mathrm{CO}_{2}$ levels of Eugenei clones were less sensitive to $A B A$ accumulation than were Tristis clones, although Eugenei clones accumulated substantially more $\mathrm{ABA}$. Tristis clones, on the other hand, were sensitive to $\mathrm{ABA}$ concentrations but accumulated a much smaller amount. This difference may lead to contrasting physiological responses of the two clones in the face of a prolonged drought.

\section{Information Dissemination}

Dickmann, D. I., Z. Liu, P. V. Nguyen, and K. S. Pregitzer. 1991. Photosynthesis, water relations, and growth of two hybrid Populus genotypes during a severe drought. Submitted to Canadian Journal of Forest Research.

Dickmann, D. I. 1991. The role of physiology in tree breeding. Oral paper presented at the IUFRO Biological Systems in Tree Breeding Conference, Helsinki, Finland, September 10-13. Manuscript in preparation for submission to conference proceedings to be published as a special issue of Sivae Fennica.

Dickmann, D. I., and K. S. Pregitzer. 1991. The structure and dynamics of root systems of short-rotation woody plants. Oral paper presented at the IEA Conference, Physiology of Short-Rotation Crops, Uppsala, Sweden, September 23-25.

Manuscript submitted for publication in conference proceedings. 


\subsection{MISSISSIPPI AGRICULTURAL \& FORESTRY EXPERIMENT STATION-EARLY SELECTION CRITERIA AND CLONAL PROPAGATION METHODS FOR INCREASED PRODUCTIVITY OF SYCAMORE IN SHORT- ROTATION ENERGY SYSTEMS}

Investigator: S. Land

\section{Goaks}

To provide basic descriptive information on characteristics of American sycamore (Platanus occidentalis L.) reproductive materials (seeds, seedlings, rooted cuttings, and tissue culture plantings); determine magnitudes of genetic and common-environmental (maternal) effects; estimate sizes of juvenile-"mature" genetic correlations; develop "hedging" techniques for production of rooted cuttings; and determine tissue culture techniques for production of plantings.

\section{Highlights}

Six stages of flower development of American sycamore have been described and used to determine optimum control-pollination procedures (Land 1991). Seeds of 6 control-pollinated reciprocal crosses and 16 open-pollinated families were germinated and planted in containers in February 1991. Containerized seedlings were transplanted to a nursery study and a field study in July. Measurements have been taken for rate of germination, early growth of the germinants, height and diameter growth of the seedlings, and leaf area development. These traits will be correlated with 1991 and 1992 growth to determine which traits might be used for early selection.

Hedging (top pruning) of mature sycamore trees and spraying the hedged trees with benzyl adenine in 1987 resulted in some rejuvenation of the cuttings taken from the sprouts in March 1988 (Land et al. 1991). Rejuvenation was indicated by an increase of $26 \%$ in rooting success of the cuttings. Cuttings of $>14-\mathrm{mm}$ diam with a bud node within $2 \mathrm{~cm}$ above the cut base increased rooting success also. After being outplanted and grown for one season in the field (October 1989), the stecklings (i.e., rooted cuttings) had produced $2.13 \mathrm{Mg} / \mathrm{ha}$ at a $1.2 \mathrm{~m} \times 3.6 \mathrm{~m}$ spacing. Subsequent tests in 1989-1991 have indicated that rooting success of cuttings is (1) reduced in outdoor nurseries by late frosts at the time of bud break (March); (2) reduced by moving the cuttings from greenhouse to nursery 1 month (April) after planting in the greenhouse; (3) not equal to initial sprouting 
because nearly half of the sprouted cuttings die during the third month (June) after the unrooted cuttings are planted (Table 2); (4) not improved by basal dips in powders or concentrated liquids of growth regulators; (5) greatly affected by clonal origin; and (6) increased by taking cuttings from stump sprouts of stecklings rather than from 3-year-old sprouts of the originally-hedged tree (Table 2).

Table 2. Effects of source of cuttings (from the same clone) on survival of cuttings in May and June 1991 following planting on March 20, 1991, in an outdoor nureery

\begin{tabular}{lll}
\hline \multicolumn{1}{c}{ Source of cuttings } & \multicolumn{2}{c}{ Survival (\%) } \\
\cline { 3 - 3 } & May & June \\
\hline 3-year-old sprouts on hedged 10-year-old trees & $29 \mathrm{~B}$ & $6 \mathrm{a}$ \\
Limbs on 3-year-old stecklings & $40 \mathrm{AB}$ & $15 \mathrm{a}$ \\
1-year-old sprouts on hedged 3-year-old stecklings & $60 \mathrm{~A}$ & $29 \mathrm{a}$ \\
Study average & 43.1 & 16.7 \\
\hline
\end{tabular}

Treatment effects followed by the same letter are not statistically different.

Leaf discs or buds, rather than seeds, will have to be used as explant sources for tissue culture because the seeds cannot be effectively surface sterilized. Use of $40 \%(w / v)$ calcium hypochlorite will provide acceptable reduction in contamination rate (to $<10 \%$ ) for (1) leaf discs from greenhouse-grown seedlings and (2) the youngest buds (No. 1-No. 5 down from the apical meristem). Callus formation, but little root or shoot development, has been obtained on cotyledon, epicotyl, and hypocotyl sections from young germinants under various concentrations of 2,4-D and benzo[a]pyrene (BAP). Tissue pieces from the radicle had much less callus formation ( $21 \%$ vs 87 to $100 \%$ for the other tissue sources).

\section{Information Dissemination}

Land, S. B., Jr. 1991. Stages of flower development and control-pollinated seed yields for American sycamore. Proceedings of the 21st Southern Forest Tree Improvement Conference, June 17-20, 1991, Knoxville, Tenn. (In press) 
Land, S. B. Jr., W. W. Elam, and M. Khan. 1991. Rejuvenated sycamore cuttings for energy plantations. 1991 Southern Biomass Conference, January 7-10, 1991, Baton Rouge, LA. (Submitted for publication in Biomass)

\section{OAK RIDGE NATIONAL LABORATORY-BIOCHEMICAL AND MOLECULAR BASES OF WATER STRESS TOLERANCE OF POPLAR}

Investigator: T. J. Tschaplinski

Goaks

The long-term goal is to identify biochemical/molecular traits that can be used during genetic selection to rapidly screen for water stress tolerance in a traditional breeding program or in a somaclonal selection program via tissue culture. The primary objectives of the proposed research are (1) to determine the degree of genetic variability in and limits of water stress tolerance in existing poplar (Populus) clones; (2) to characterize the biochemical and molecular bases of water stress tolerance in responsive poplar clones; and (3) to develop biochemical and molecular screening procedures based on in vivo and/or in vitro materials that can be utilized to identify poplar clones that express maximum water stress tolerance.

\section{Highlights}

During the field season $\mathbf{1 0}$ clones were screened for water stress tolerance in a greenhouse, and 12 were screened outdoors. Light levels were not near saturation in the greenhouse, potentially limiting the expression of osmotic adjustment. Stress-testing outdoors focused on one family, including four $P$. deltoides $\times P$. trichocarpa hybrids (No. 53239, No. 53240, No. 53242, and No. 53246 and the two parents. After 9 weeks of repeated stress cycles, all hybrids displayed some degree of osmotic adjustment (after terminal bud set). Stressed trees of the male clones had the greatest degree of osmotic adjustment (0.25 $\mathrm{MPa})$, compared with small adjustments $(0.10 \mathrm{MPa})$ in the female hybrids. By the final harvest on October 11, all three male clones had higher main stem dry weight under stress conditions than did the female clones. The growth advantage of male clones was attributed to both osmotic adjustment and maintenance of a strong central tendency. In contrast, female clones allocated more dry matter to numerous lateral meristems when under stress and displayed lesser degrees of osmotic adjustment. It 
was tentatively concluded that the male $P$. deltoides parent conferred the water stress tolerance capability on its hybrid progeny.

Information Disemination

None

\section{SOUTHERN ILUNOIS UNIVERSITY_GENETIC BIOMASS AND GROWTH ANALYSIS OF CLONAL SILVER MAPLE (ACER SACCHARINUM L) IN SEVERAL LOCATIONS}

Investigators: W. C. Ashby, J. E. Preece, and P. L. Roth

Gools

To select and test 4 outstanding clones each of silver maple (Acer saccharinum $\mathrm{L}$ ) from 15 of 26 different provenances collected throughout the eastern United States and southeast Canada during the spring and early summer of 1987 . These 60 clones will be outplanted in replicated studies in 1991 in Minnesota and on both upland and bottomland sites in Carbondale, Illinois. Plans are to plant other remote sites in the spring of 1992.

\section{Highlights}

Micropropagated silver maple plantlets were planted in a bottomland and an upland plantations near Carbondale, Illinois, during June 1991. Ten blocks of 60 clones, 4 clones each from 15 provenances with 3 plantlets per clone, were planted in a randomized complete block design through a $1.1 \mathrm{~m}$ wide, $0.03 \mathrm{~mm}$ (1.25 mil) thick whiteon-black plastic mulch. Although there was a severe drought during the summer of 1991, there was a $95 \%$ and $93 \%$ survival rate in upland and bottomland plantations, respectively. During the first growing season, trees grew taller on the upland site. The mulch resulted in negligible soil erosion, conserved soil moisture, and facilitated weed control. In Minnesota, micropropagated trees were planted to complete an earlier plantation or lined out for planting a second plantation in the spring of 1992.

Improvements were made during the large-scale production phase of our micropropagation operation. These have included in vitro root initiation of microshoots, followed by transplanting to preformed peat rooting plugs (Technicultureø) in highhumidity trays and close monitoring of the new plantlets. Plant vigor, survival, and 
establishment were improved by selecting only high-quality microshoots to be used for rooting. Following rooting and acclimatization, plantlets in plugs were transplanted with no shock or delay in growth into RootMaster containers in the greenhouse. Plantlets were then hardened in a lath house or by overwintering in the field prior to transplanting into the plantations. Container-grown plantlets at least $30 \mathrm{~cm}$ tall established better in the field than shorter plantlets.

A study on rooting of leafless $20-\mathrm{cm}$-long silver maple cuttings placed directly into the soil in the field was conducted this year. This was a follow-up to similar experiments conducted in 1989 and 1990. During this year, we compared a factorial arrangement of two planting depths, two provenances (Indiana and Tennessee), soaking cuttings overnight in water or not, and Thiram fungicide with and without auxin. Thiram alone, averaged across all other treatments, resulted in the best rooting (32\%) compared with Rootone (20\%). Cuttings with $10 \mathrm{~cm}$ above the ground and/or nonsoaked rooted better than those with only the uppermost bud exposed and/or soaked overnight before planting. The best plots (47\%) were Thiram, treated and planted with $20 \mathrm{~cm}$ aboveground.

Preliminary isozyme analysis has been done on selected silver maple clones. There was good resolution on isozyme bands with the following enzyme systems: 6 phosphogluconic dehydrogenase, isocitrate dehydrogenase, diaphorase, phosphoglucoisomemrase, phosphoglucomutase, and aconitase. Many of the clones were homozygous for many of these alleles, but with all systems, some clones were shown to be heterozygous. At this time, because of the preliminary nature of the study, it can be said that isozyme analyses are promising for silver maple clones.

\section{Information Dissemination}

Preece, J. E., C. A. Huetteman, W. C. Ashby, and P. L. Roth. 1991. Micro- and cutting propagation of silver maple. I. Results with Adult and Juvenile Propagules. J. Amer. Soc. Hort. Sci. 116(1): 142-148.

Preece, J. E., C. A. Huetteman, W. C. Ashby, and P. L. Roth. 1991. Micro- and cutting propagation of silver maple. II. Genotype and Provenance Affect Performance.

J. Amer. Soc. Hort. Sci. 116(1): 149-155.

Ashby, W. C., D. F. Bresnan, C. A. Huetteman, J. E. Preece, and P. L. Roth. 1991.

Chilling and bud break in silver maple. J. Environ. Hort. 9(1): 1-4. 


\section{USDA FOREST SERVICE NORTH CENTRAL FOREST EXPERMMENT STATION-INCREASING YIELDS OF POPLAR ENERGY PLANTATIONS}

Investigator: J. G. Isebrands

Goak

To improve poplar (Populus spp.) biofuels yields from biomass through selection based on physiology research and by improving critical traits through biotechnology.

\section{Highlights}

An ecophysiological growth process model of poplar (ECOPHYS) was described and validated in the peer-reviewed literature. The model was also applied in evaluating the effects of changing environmental stresses on poplar growth in Response of Plants to Multiple Stresses, published by Academic Press. ECOPHYS was also used in parallel with field experiments on photosynthesis to develop sampling strategies. Early selection criteria based on morphological and physiological traits were documented in the scientific literature, and validation at an independent location began.

Somaclonally selected herbicide-tolerant hybrid poplars were field tested during the summer of 1991. Hardwood cuttings were collected from stool beds during the previous winter, rooted in the greenhouse in spring, and planted in the field in June. The U.S. Forest Service funded the installation of a well and irrigation system previous to field planting. Two Roundup-tolerant and four Oust-tolerant subclones were treated in midsummer with commercial rates of herbicide. Final data are currently being collected and analyzed.

Physiological characterization experiments were initiated to determine productivity rates of somaclonally selected and genetically engineered hybrid poplars. Two replications of biomass experiments were completed with the somaclones, and the first replication is in progress with the genetically engineered poplars for comparison with completed tests at Texas A\&M University. Results of cooperative research experiments in Texas preliminarily determined that genetically engineered poplars did not differ from unselected parent clones in biomass accumulation and photosynthetic efficiency. 


\title{
Information Dissemination
}

Dickson, R. E., and J. G. Isebrands. 1991. Leaves as regulators of stress response. pp. 3-34. IN H. Mooney et al. (eds.), Response of Plants to Multiple Stresses. Academic Press, New York.

Michler, C. H. 1991. Biotechnology of woody environmental crops. HortScience 26(8): 1042-1044.

Michler, C. H., and E. O. Bauer. 1991. High frequency somatic embryogenesis from leaf tissue of Populus spp. Plant Sci. 77: 111-118.

\section{USDA FOREST SERVICE NORTH CENTRAL FOREST EXPERIMENT STATION-SHORT-ROTATION WOODY CROP TRIALS FOR ENERGY PRODUCTION IN THE NORTH CENTRAL UNITED STATES}

\author{
Investigator: E. A. Hansen
}

\section{Goak}

To establish large (8-ha) plantations to obtain estimates of biomass yields and production costs of wood energy in the North Central region of the United States.

\section{Highlights}

Performance of more than 100 poplar hybrids across the region was analyzed. Data from 3- and 4-year-old trees planted in randomized small plots show that individual clones have a strong tendency for constant performance across the region, relative to other clones. In other words, a set of clones that performs well at one site tends to perform well at other sites. From this analysis, all clones from all sites in the region were ranked in a single list. During the 1991 fall measurements, observations were made for disease incidence, winter dieback, and overall tree vigor. These observations eliminated several clones that otherwise would have ranked among the top $\mathbf{4 0}$ clones. Of the remaining 31 clones, 23 generally performed well across the region, 3 clones performed well only in the more-arid Dakotas, and 5 clones performed well near Lake Superior. It is expected that many of the 31 clones will be discarded by the time the 10 -year test period is completed. Twenty-two of these clones are in production at a Minnesota Department of Natural Resources nursery as an intermediate scale-up prior to release to private nurseries. 
Biomass data were collected and summarized for 3- and 4-year-old hybrid poplar plantations. Biomass production ranged up to $6.7 \mathrm{Mg} \mathrm{ha}^{-1}$ year ${ }^{-1}$ in 4-year-old plantations. Biomass production rate accelerated sharply between years 3 and 4. Growth data for 4 and 5-year-old plantations have just been collected and will be summarized soon.

The plantations encompass a broad range of soil and climatic conditions and provide a unique opportunity to study site/productivity relationships. Soil sampling has been completed and includes 24 soils at 17 plantations. The final data analysis and report of this investigation will be completed in winter of 1992 . Preliminary analyses show a strong negative correlation of latitude and a positive correlation of soil carbon to tree height. These variables are in turn correlated with temperature, precipitation, soil-water availability, and potential evapotranspiration. When the data set is completed, biomass yield will be regressed against these more fundamental variables. The hypothesis is that water availability is the predominant factor influencing hybrid poplar biomass yields in this region. Therefore, it will be determined if biomass yields increase with precipitation, soil water availability, and decreasing evaporative demand. It is also expected that yields will increase with temperature or some index of growing-degree day.

Older hybrid poplar plantations have been identified at ten locations throughout the region. At each site soils were sampled both within the plantations and immediately adjacent in row crop or grain fields and in grass, hay, or pasture. The objective is to determine if planting hybrid poplar in agricultural lands results in measurable increases in soil carbon, in addition to the large production of aboveground carbon. Soil sampling has been completed and sample preparation is in process prior to laboratory analysis.

DOE NREL/ORNL are planning a research and development (R\&D) liquid-fuel ethanol plant project. We are participating locally by undertaking a NREL-funded study of wood degradation while in chip-pile storage. We are also developing preliminary plans with state Resource Conservation and Development, DNR, and university staff to prepare for possible participation in an R\&D woody crops feedstock/ethanol plant project.

\section{Information Disecmination}

Presentations

DOE Biomass Feedstock/Conversion Scale-up Activities and Issues. Washington D.C. June 19, 1991. 
EPRI Whole-tree Burning. Working Group Meeting. Nashville, Tenn. April 17, 1991.

Minnesota Whole-tree Burner Planning Meeting. Fairmont, Minn. June 20, 1991.

ASAE Annual Contractors Coordination Meeting. Dearborn, Minn. October 31, 1991.

Arbor Day Institute, First National Fuelwood Conference. Lincoln, Nebr. November 11, 1991.

\section{Publications}

Hansen, E. A. 1990. Early yields of biomass plantations in the north central United States. USDA Forest Service, North Central Forest Experiment Station, St. Paul. Research Note NC-353. 6 pp.

Hansen, E. A. 1991. Energy plantations in north central United States: Status of research and development plantations. Energy Sources 13(1): 105-110.

\section{USDA FOREST SERVICE PACIFIC NORTHWEST RESEARCH STATION-INCREASING THE PRODUCTIVITY OF BIOMASS PLANTATIONS OF ALDER AND COTTONWOOD IN THE PACIFIC NORTHWEST}

Investigator: D. S. DeBell

\section{Goaks}

To develop guidelines for crop management and identify morphological and physiological traits that might be used for evaluating and improving cultural practices and for selecting superior genotypes.

\section{Highlights}

At the end of the fifth (1990) growing season, red alder trees and poplar hybrids in Plantation I averaged 6.6- and 10.6-m tall, respectively; mean survival exceeded $96 \%$ at the widest spacings. Trees in the best treatments for each genus were substantially larger. Effects of spacing were evident in plantings of both genera. Fertilizer tests identified phosphorus as the nutrient most likely to stimulate alder growth and nitrogen and lime as additives that will improve cottonwood growth. Irrigation caused dramatic increases in the growth of alder and moderately improved the growth of cottonwood. 
The yield comparison between "woodgrass" (0.18 and $0.30 \mathrm{~m})$ and wider spacings $(>0.50 \mathrm{~m}$ ) has been completed. Mean annual production in the woodgrass treatments did not differ between the two clones (D-01 and H-11) or two spacings ( 0.18 and $0.30 \mathrm{~m}$ ), averaging 6.4 to 7.0 tha over the 5-year period. The highest yield was produced in the second year (first year of coppice), and it declined thereafter (Fig. 2). Cumulative growth in the wider spacings was substantially better than in the two woodgrass spacings. Per hectare yields of clone $\mathrm{H}-11$ in the wider spacings at age 5 were two to three times greater than those obtained with woodgrass; yields of clone D-01 in the widest spacing (2.0-m) averaged $17 \%$ greater than those of woodgrass, and yields of clone D-01 in the 0.5- and 1.0-m spacings were about $60 \%$ greater than woodgrass yields. Woodgrass shows little promise as a viable system for growing Populus for biomass. On the other hand, yields in the wider spacings, especially for clone $\mathrm{H}-11$, were substantially higher than previously expected, averaging about $18 \mathrm{tha}^{-1}$ year ${ }^{-1}$. Thus, possibilities for application of the wide-spaced regimes are considerably brighter than for woodgrass.

A new Populus plantation established in March 1990 has had outstanding growth. Four clones (three $P$. trichocarpa $\times P$. deltoides hybrids and one local $P$. trichocarpa clone) were planted in replicated pure and mixed clonal blocks at three spacings. Mean heights at the end of the first year for various clones in pure blocks ranged from 2.7 to $3.7 \mathrm{~m}$; differences among clones, clonal mixtures, and spacings were apparent. At the end of the second growing season mean heights in pure plots ranged from 5.1 to $7.0 \mathrm{n}_{\mathrm{t}}$ and, in mixed plots, from 3.4 to $7.1 \mathrm{~m}$. Heights were lowest in the closest spacing for all four clones; the difference in height between the closest spacing and the spacing with the best growth was much less for the native $P$. trichocarpa clone $(0.5 \mathrm{~m})$ than for the three hybrids (1.4 to $1.5 \mathrm{~m}$ ). At the two closest spacings, the three hybrids had better height growth in mixed than in pure clonal plots, whereas the native clone grew better in pure plots.

Crown structure and dynamics, competition, and physiological processes and conditions in leaves are being characterized to provide the basic underpinning for crop-management guidelines and tree-selection criteria. 


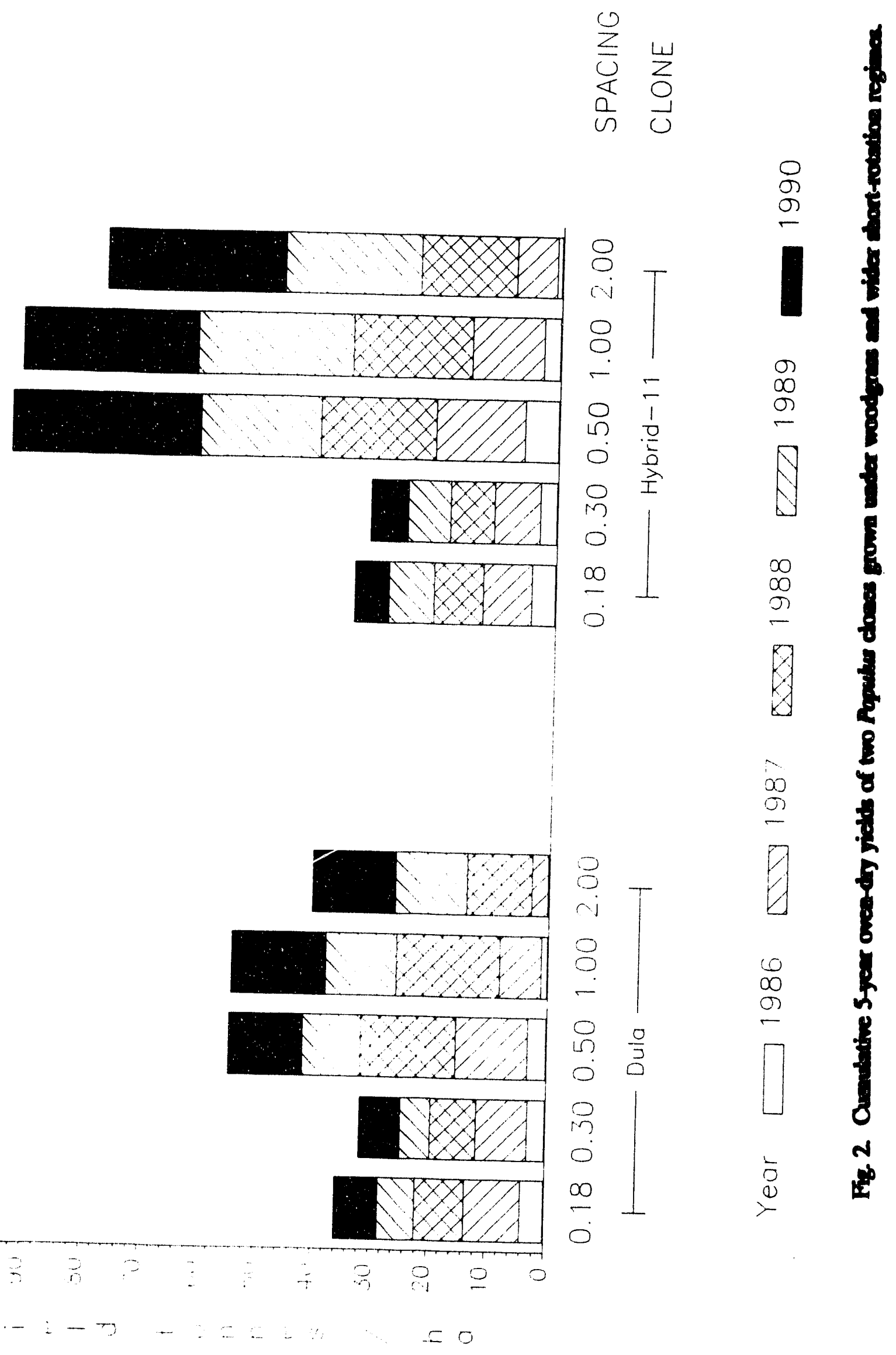


Information Discemination

Dunlap, J. M. 1991. Genetic variation in natural populations of Populus trichocarpa T. \& G. from four river valleys in Washington. $\mathrm{PhD}$ Thesis, University of Washington, Seattle. 447 pages.

Scarascia-Mugnozza, G. E., J. G. Isebrands, T. M. Hinckley, and R. F. Stettler. 1989. Dynamics of light interception, leaf area, and biomass production in Populus clones in the establishment year. Ann. Sci. For. 46 (suppl.): 515s-518s.

Ceulemans, R. J., R. F. Stettler, T. M. Hinckley, J. G. Isebrands, and P. E. Heilıan. 1991. Crown architecture of Populus clones as determined by branch orientation and branch characteristics. Tree Phys. 7: 157-167.

Heilman, P.E., R.F. Stettler D.P. Hanley, and R.W. Corkner. 1991. High Yield Hybrid Poplar Plantations in the Pacific Northwest. PNW Extension Bulletin No. 356. Washington State University Coop. Extension, 32 p.

Stettler, R.F. and R. Ceulemans. 1991. Clones as a focus for genetic and physiological research in forest trees. IN: M. Raj Ahuja and W.J. Libby (eds.), Clonal Forestry: Genetics, Biotechnology and Application. Springer (in press).

\subsection{UNIVERSITY OF WASHINGTON_GENETIC IMPROVEMENT AND EVALUATION OF BLACK COTTONWOOD FOR SHORT-ROTATION BIOMASS PRODUCTION}

Investigators: $\quad$ R. F. Stettler, P. E. Heilman, T. M. Hinckley, and H. D. Bradshaw, Jr.

\section{Goak}

To (1) genetically improve black cottonwood (Populus trichocarpa) for biomass production, (2) elucidate critical components of productivity and the ways in which they can be manipulated genetically and environmentally, and (3) engage in technology transfer to encourage poplar culture in the Northwest.

Since 1988, breeding in the University of Washington/Washington State University Poplar Research Program has been aimed at elucidating the genetic basis of productivity in Populus trichocarpa $(\mathrm{Pt}) \times P$. deltoides $(\mathrm{Pd})$ hybrids. Rapid progress is being made in this effort by combining conventional breeding with molecular analysis of the progeny. 
Because the two parental species (Pt and Pd) differ markedly in many aspects of growth and development, their advanced generation progeny (backcross and $F_{2}$ ) segregate for many phenotypic traits related to productivity. Most of these traits are under polygenic inheritance and don't behave in a simple Mendelian fashion. Associating them with DNA markers on the 19 chromosomes of Populus is the ultimate purpose of constructing a high resolution map of the poplar genome.

To date, well over 100 marker loci have been mapped by using restriction fragment length polymorphisms (RFLPs) detected by Southern blotting. This map is now being converted to one based on the polymerase chain reaction (PCR). PCR is the most effective way to determine the marker genotypes of the large numbers of progeny required for associating quantitative traits with specific regions of the chromosomes. While Southern blotting uses relatively large amounts of highly purified poplar DNA and takes several days to perform a few dozen genotype determinations, PCR uses only $1 / 100$ as much DNA from a crude preparation and can be performed on hundreds of samples in a few hours. As an illustration of the power of PCR, tree genotypes at 50 loci can be determined using the DNA from a single leaf disk collected with a paper punch.

One spinoff of the mapping effort has been the identification of triploid hybrid clones. Molecular analysis revealed that they carried two doses of Pt chromosomes and one dose of Pd chromosomes. As shown in Fig. 3, triploid hybrids have a higher DNA content per nucleus (Fig. 3A), larger epidermal cells (Fig. 3B), and resemble their Pt parent more than do their diploid full sibs (Figs, 3C-D). More important, triploids tend to have larger leaves, often grow more rapidly, and have longer wood fibers than normal diploids, thus increasing quantity and quality of fiber production. Triploids are usually sterile, preventing hybrid pollen and seed from contaminating the germ plasm of native populations. Breeding for triploidy is a potentially attractive avenue to poplar improvement and will be more fully explored in this program.

A second spinoff is the genetic fingerprinting of hybrid poplar clones. The unequivocal identification of individual clones is an essential prerequisite for any program that exploits the clonability of select genotypes. Past practice in poplar culture has relied primarily on morphological and phenological criteria. However, misidentification is common and errors can be costly. RFLP profiles now provide a new tool for the reliable identification of poplar clones. This procedure was applied to unambiguously discriminate 

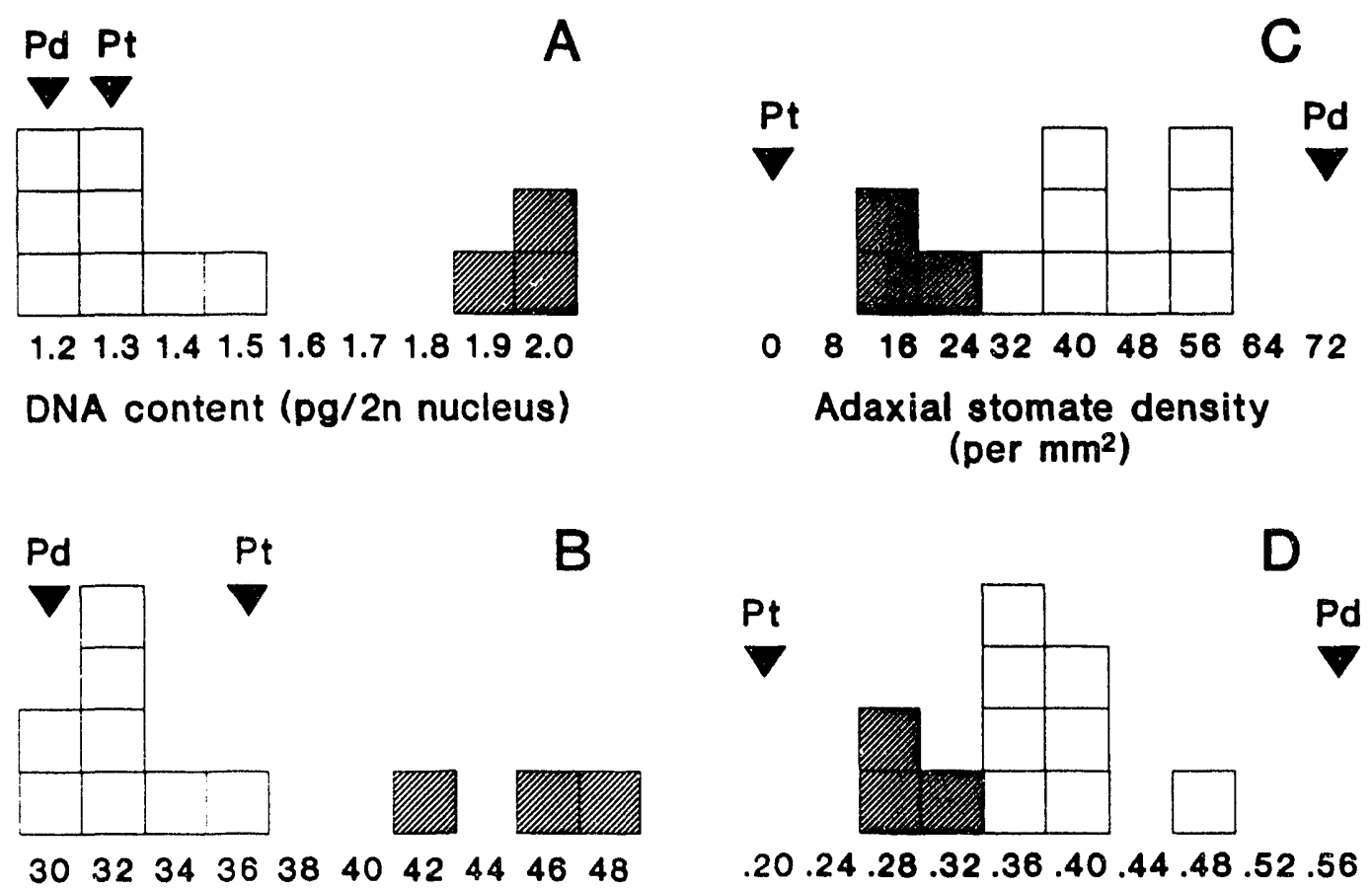

Epidermal cell diameter (um)

Petiole length:blade length ratio

$\square$ diploid

tri/aneuploid

Fig. 3. Trait variation among 11 members of a Populus trichocapp $(P t) \times P$. deltoides (Pd) croses, including both diploid and triploid/aneuploid progeny. Parental values are indicated by arrows. Triploids contain two doses of $\mathrm{Pt}$ chromosomes and a single dose of Pd chromosomes. 
among 12 hybrid clones selected by the Boise Cascade Corporation for their plantation program in eastern Washington. Another collaborating company, James River Corporation, will take advantage of this technology in conjunction with patent applications for elite $P$. deltoides material.

In summary, the integration of conventional breeding with new molecular tools has proved to be eminently fruitful in the UW/WSU Poplar Research Program. Practical technology has already been transferred to the private sector in the region. More important, this integration has estabiished a new paradigm for the collaborative effort among researchers from many disciplines. The major benefits will be that (1) future research results can be more coherently interpreted and (2) the search for increased biomass production in poplar can be pursued more systematically and more incrementally.

\section{Information Discemination}

Dunlap, J. M. 1991. Genetic variation in natural populations of Populus trichocarpa T. \& G. from four river valleys in Washington. Ph.D. Thesis, University of Washington, Seattle. $447 \mathrm{p}$.

Scarascia-Mugnozza, G. E., J. G. Isebrands, T. M. Hinckley, and R. F. Stettler. 1989. Dynamics of light interception, leaf area and biomass production in Populus clones in the establishment year. Ann. Sci. For. 46 (suppl.): 515s-518s.

Ceulemans, R. J., R. F. Stettler, T. M. Hinckley, J. G. Isebrands, and P. E. Heilman. 1991. Crown architecture of Populus clones as determined by branch orientation and branch characteristics. Tree Phys. 7: 157-167.

Heilman, P. E., R. F. Stettler, D. P. Hanley, and R. W. Corkner. 1991. 'Tigh yield hybrid poplar plantations in the Pacific Northwest. PNW Extension Bulletin No. 356. Washington State University Corp., Extension, 32 p.

Stettler, R. F. and R. Ceulemans. 1991. Clones as a focus for genetic and physiological research in forest trees. IN: (M. Raj Ahuja and W.J. Libby eds.), Clonal Forestry: Genetics, Biotechnology and Application. Springer (in press). 


\section{MODEL HERBACEOUS ENERGY CROPS}

The goal of the Model Herbaceous Energy Crops component is to develop herbaceous energy crops that are attractive to both growers and processors. In 1991, new research studies were designed for switchgrass (Panicum vingatum). The new work will consist of genetic selection of new and improved varieties suitable for sustained and extensive biofuels production, development of physiological indicators to be used in breeding and evaluation strategies, development of tissue cult: e techniques for rapid propagation of varieties, and documentation of cultural and genetically based improvement of yield level and stability for existing and newly developed varieties under representative field conditions. The regional focus of this new switchgrass research will be the southeastern and south central United States, where switchgrass yield potential aypears quite high. Projects will be selected through a compet'tive solicitation scheduled for release in November 1992.

A study on biomass prorluction by fescue and swiichgrass alone and in mixed swards with legumes will be completed in 1992. Iowa State University and North Dakota State University will continue research in the north central United States on screening and selection of herbaceous energy crops. Studies $c$ in the effects of storage on switchgrass composition and on the development o: winter rapeseed varieties for double-cropping in the Southeast were completed in 1991. Auburn University will complete two studies in 1992-one on the variability for biomass and plant composition in sericea lespedeza germ plasm and one evaluating switchgrass, napiergrass, and energy cane. Brief highlights of subcontracted work on herbaceous species follows.

\subsection{AUBURN UNIVERSITY-VARIABIIITY FOR BIOMASS PRODUCTION AND PLANT COMPOSITION IN SERICEA LESPEDEZA GERM PLASM}

Investigator: J. A. Mosjidis

\section{Goak}

To determine the variability for biomass production and plant composition among 81 genotypes of sericea lespedeza. 


\section{Highlights}

A field experiment aimed at measuring biomass yield of 81 genotypes of sericea lespedeza over time and variation in biomass composition was conducted. Results indicated substantial differences for biomass yield among sericea lespejeza genotypes. However, dry matter content was the same. Genotype R194-79-290-9 had the highest mean biomass yield and consistently ranked among the top four during t' $e$ years that this study was conducted. Other genotypes that also had a good performance over the 4 years are the cultivar Serala and the breeding line 75-2-3. Overall, it is not possible to decide which of the top 16 genotypes (top 20\%) is the best because this study was conducted in $o^{r}$ ly one location. However, it is clear that it is possible to select sericea lespedeza genotypes with a consistently high biomass yield. No significant differences were found among genotypes for percentage of crude protein content. Crude protein contents were found to be substantially lower (about 25\%) than those previously reported by other researchers. Distribution of sericea lespedeza genotypes for crude protein content is presented in Fig. 4. There were significant differences among genotypes for NDF, hemicellulose, and holocellulose content. Distribution of sericea lespedeza genotypes for NDF content is presented in Fig. 4 and for hemicellulose and holocellulose content is presented in Fig. 5. There were not significant differences among genotypes for ADF, lignin, and cellulose content. Distribution of sericea lespedeza genotypes for ADF content is presented in Fig. 4 and for lignin and cellulose content is presented in Fig. 5. In short, therc is variability for biomass yield and for some quality traits that are considered important for biofuel production. Thus, it is possible to select sericea lespedeza genotypes within the breeding lines tested that would be particularly adapted for some methods of biofuel production. Further testing of the best genotypes should be conducted at several locations to determine the genotype to be released for the specific purpose of biomass production. Screening of accessions from the Plant Introduction System should be conducted to determine their variability for biomass yield and for quality traits. If the results are positive, recombination of particular traits, using genetic procedures, could be carried out to obtain plants with higher levels of desirable traits.

\section{Information Dissemination}

None. 

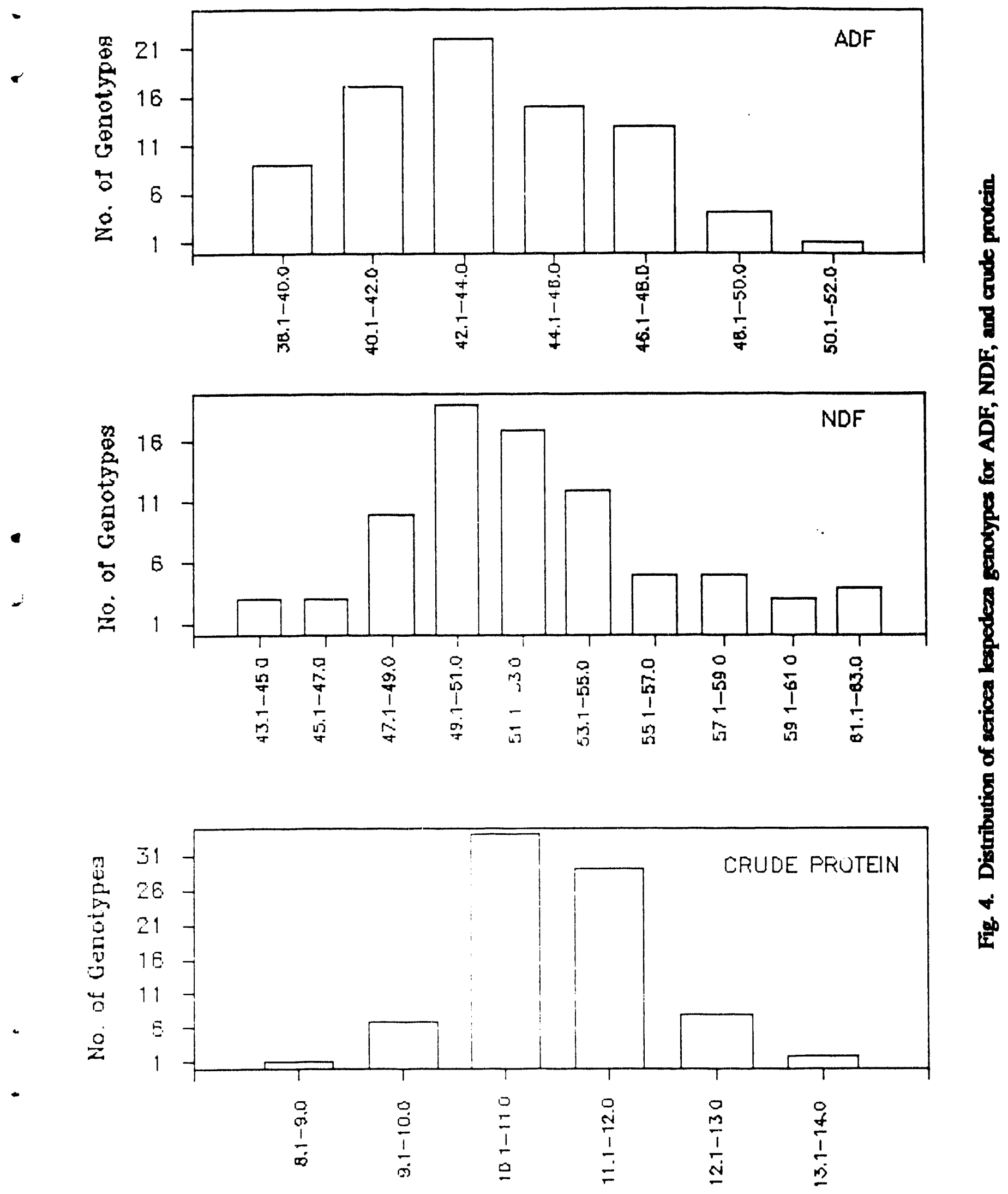

ล 


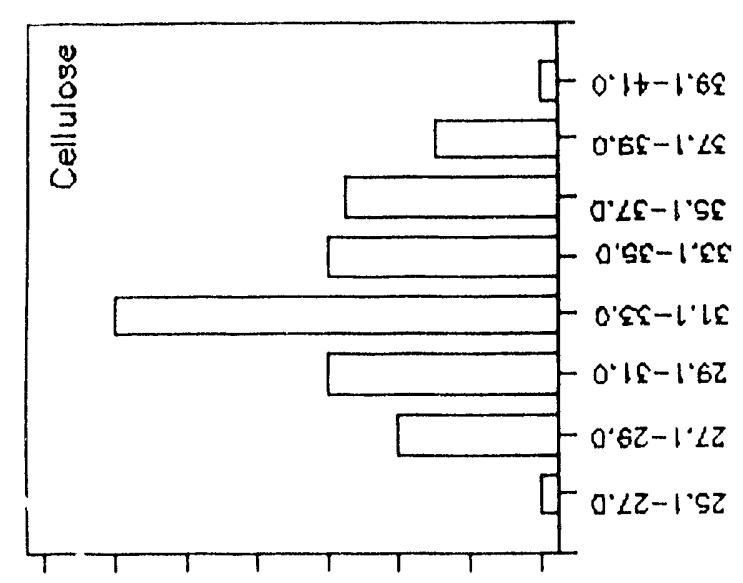

ar $n=m$ or $n=$

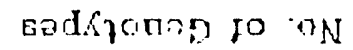

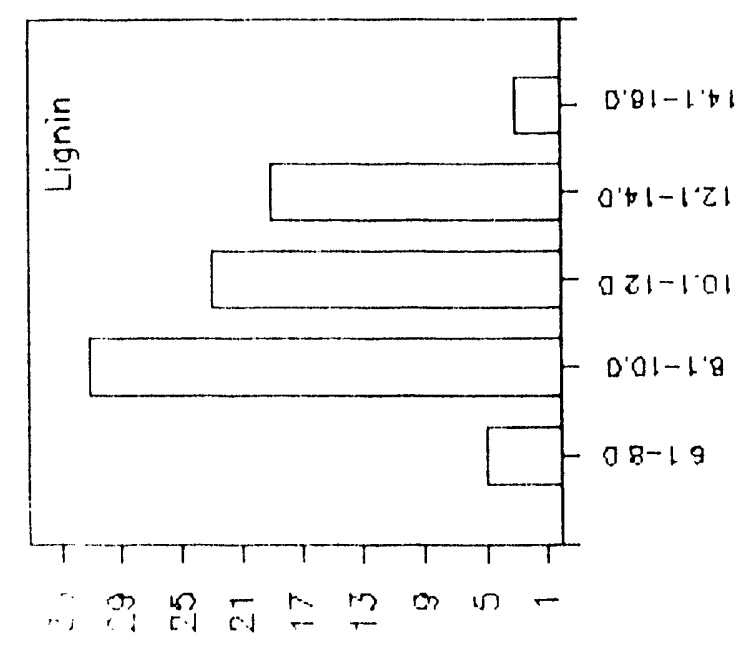

gad $\angle 70105$ jo $0 \mathrm{~N}$
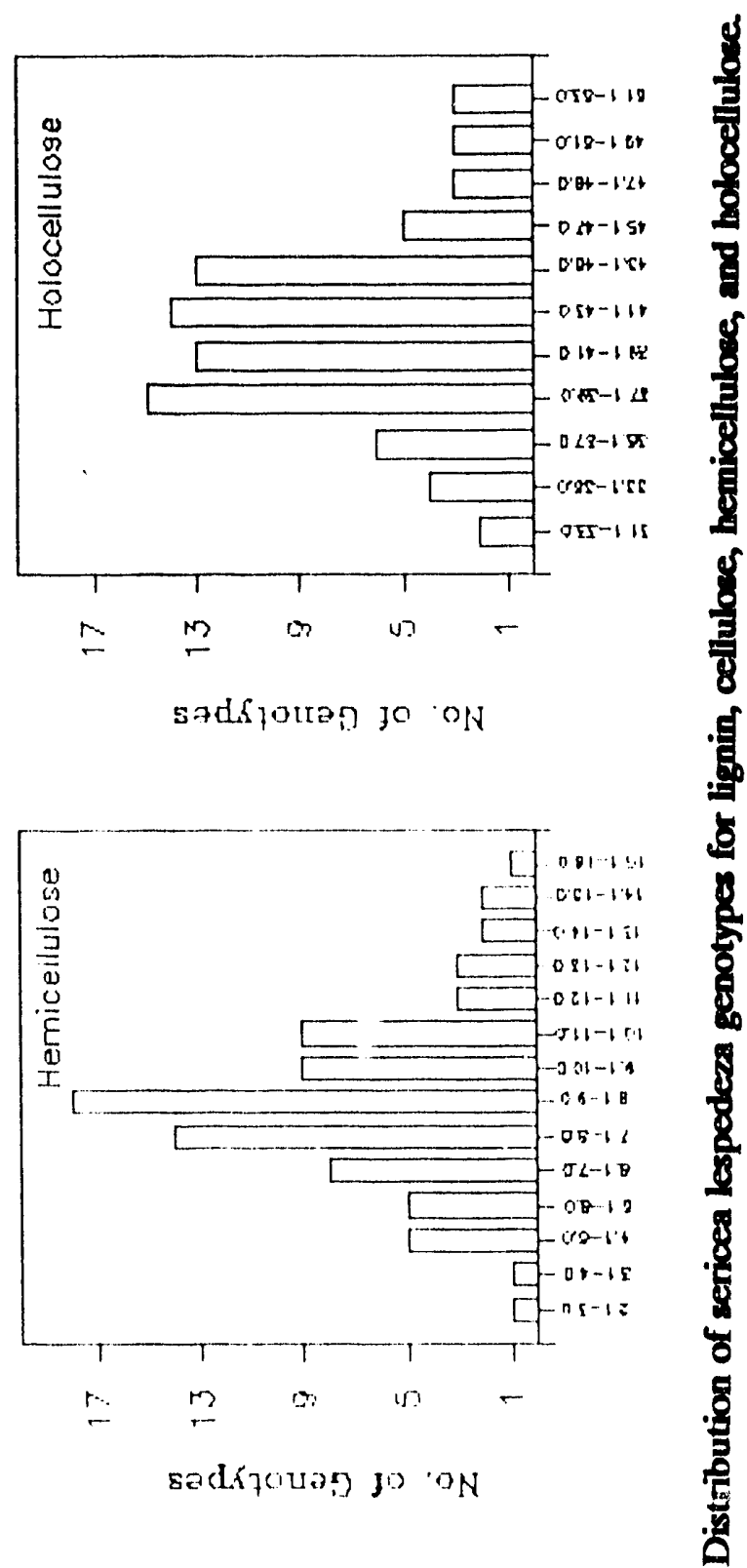

i

它 


\subsection{AUBURN UNIVERSITY-SELECTION AND IMPROVEMENT OF HERBACEOUS ENERGY CROPS FOR THE SOUTHEASTERN USA}

Investigator: D. I. Bransby

Goak

To evaluate perennial herbaceous species for biomass production in the southeastern United States.

\section{Highlights}

Perennial forage species were compared on five sites in Alabama representative of some 43 million acres of cropland in the southeastern United States. The trials examined productivity, nutrient requirements, planting and harvesting practices, and biomass composition.

This project has been successful in identifying 'Alamo' switchgrass as an outstanding perennial herbaceous energy crop for the southeastern United States. Results from 1991 continue to indicate that this crop should be able to provide sustainable biomass yields of 20 to $30 \mathrm{Mg} / \mathrm{ha}$ (8.9-13.4 tons per acre) and a cost per metric ton of $\$ 10$ to $\$ 20$, depending on the assumptions made for economic analysis.

High yields of 'Alamo' switchgrass can be attributed partly to very early spring growth compared with other switchgrass varieties. This, in turn, could make 'Alamo' more sensitive to late freezes. However, no stand loss was observed following a late frost after 'Alamo' had started to grow in February 1991. Further research in establishment, row spacing, and breeding will probably result in further improvements in switchgrass biomass yields.

\section{Information Dissemination}

Sladden, S. E., D. I. Bransby, and G. E. Aiken. 1991. Biomass Yield, Composition and Production Costs for Eight Switchgrass Varieties in Alabama. Biomass and Bioenergy 1(2): 119-122.

Sladden, S. E., D. I. Bransby, and G. E. Aiken. 1991. Biomass Yield and Composition and Winter Survival of Tall Grasses in Alabama. Biomass and Bioenergy 1(2): 123-127. 


\subsection{UNIVERSTYY OF IDAHO_DEVELOPMENT OF BROADLY ADAPTED CULTTVARS OF WINTER RAPESEED AS A SOURCE OF DIESEL FUEL}

Investigators: D. L. Auld, K. A. Mahler

Goak

To develop varieties of rapeseed (Brassica napus) whose oil is suitable for use as a diesel fuel.

\section{Highlights}

An interdisciplinary team of researchers, with funding from both the Biofuels Feedstock Development Program and the USDA-Agricultural Research Service's Office of Energy, are working on the production, processing, and utilization of rapeseed as a diesel fuel. Regionally adapted and improved varieties have been and are being developed, and these varieties along with privately developed varieties are being field tested at sites across the United States (Fig. 6).

Four varieties released by the College of Agriculture in 1990 with broad geographic adaptation and different fatty acid compositions were granted PVP numbers: 'Rebel' (PVP 9000148), 'Aspen' (PVP 9100088), 'LEI III' (PVP 9100090), and 'Humus' (PVP 9100089).

During the 1990-1991 growing season, 69 varieties were planted at 18 locations. The highest yields occurred at two locations in the Pacific Northwest and the Atlantic coast location of Virginia. Two midwest locations (Illinois and Missouri) also had a good yield for that region of the country. Once again, weather and location influenced the establishment and survival of the trial in each production region.

A genotype $x$ environment interaction study was completed to determinine the effect of production environment on yield and quality of winter rapeseed in the United States. This study looked at the effects of production environment (location) and genotype of six winter rapeseed cultivars used as controls at each location in three cropping seasons of the National Winter Rapeseed Variety Trial. The model used in analysis of these data demonstrated the accuracy available in selecting specific cultivars with competitive yields across diverse environments. This method of statistical analysis will be useful in determining adaptation of specific varieties developed for optimum rapeseed fuel production to regions where maximum yield would be expected. 


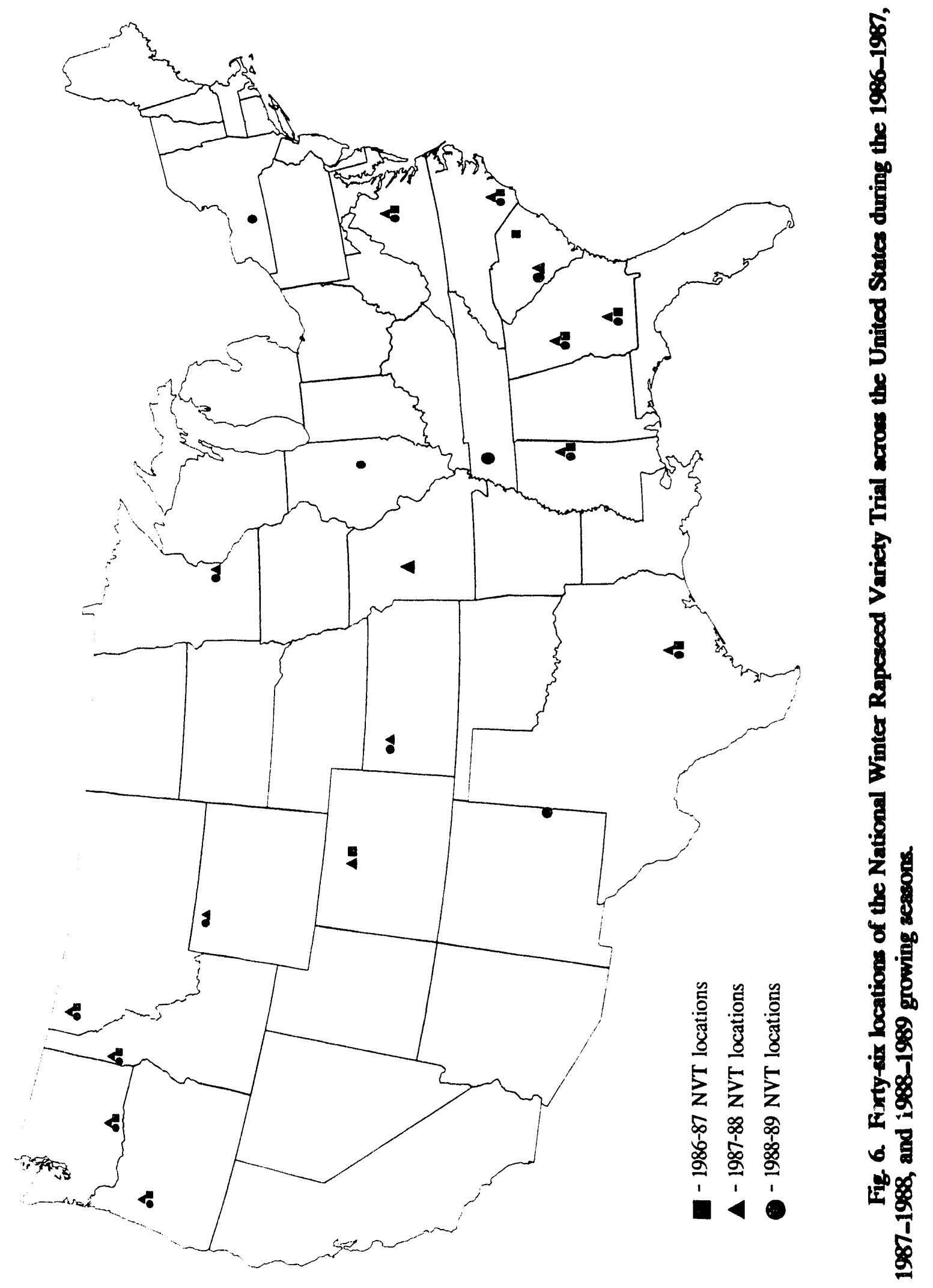




\section{Information Diacemination}

Auld, D. L and K. A. Mahler. 1991. Production of Canola and rapeseed in the U.S. 8th International Rapeseed Congress Proceedings (in press). July 9-11, Saskatoon, Saskatchewan, Canada.

Auld, D. L., K. A. Mahler, D. A. Erickson, D. C. Thill, P. L. Raymer, D. C. Bridges, and J. L. Butler. 1991. Registration of 'Rebel' rapeseed. Crop Sci. 31(2): 485-486.

Auld, D. L., K. A. Mahler, D. C. Thill, D. A. Erickson, P. L. Raymer, and J. I. Sernyk. 1991. Registration of two rapeseed germplasm populations. Crop Sci 31(2): $493-494$.

Erickson, D. A., D. L. Auld, and K. A. Mahler. 1991. High density plantirig of Brassica napus breeding lines under greenhouse conditions. 8th International Rapeseed Congress Proceedings (in press). July 9-11, Saskatoon, Saskatchewan, Canada.

Hansen, J. L., D. R. Brady, D. A. Erickson, and D. L. Auld. 1991. Rapid regeneration of dihaploid winter rapeseed. 8th International Rapeseed Congress Proceedings (in press). July 9-11, Saskatoon, Saskatchewan, Canada.

Heikkinen, M. K. and D. L. Auld. 1991. Harvest index and seed yield of winter rapeseed grown at different plant populations. 8th International Rapeseed Congress Proceedings (in press). July 9-11, Saskatoon, Saskatchewan, Canada.

Mahler, K. A., D. L. Auld, et al. 1991. National winter rapeseed variety trial, 1990-91. Idaho Agricultural Experiment Station Miscellaneous Series No. 154.

Mahler, K. A., D. L. Auld, B. Shafii, and W. J. Price. 1991. 8th International Rapeseed Congress Proceedings (in press). July 9-11, Saskatoon, Saskatchewan, Canada.

Perkins, L. A., C. L. Peterson, and D. L. Auld. 1991. Durability Testing of Transesterified Winter Rape Oil (Brassica napus L.) as Fuel in Small Bore, Multi-Cylinder, DI, CI Engines. SAE Technical Paper No. 911764. SAE, Warrendale, PA 15096-001.

Peterson, C. L., and D. L. Auld. 1991. Technical Overview of Vegetable Oil as a Transportation Fuel. IN Solid Fuel Conversion for Transportation Sector, FactVol. 12, ASME, New York, NY 10017.

Shaffi, B., K. A. Mahler, W. J. Price, and D. L. Auld. 1991. Genotype by environment interaction effects on yield and oil content of winter rapeseed. Crop Sci. (in press). 
Tonnemaker, K. A. D. L. Auld, D. C. Thill, C. A. S. Smith, and D. A. Erickson. 1991. Development of resistance to sulfonylurea herbicides in rapeseed with chemical mutagenesis. 8th International Rapeseed Congress Proceedings (in press).

July 9-11, Saskatoon, Saskatchewan, Canada.

Van der Griend, L., M. E. Feldman, and C. L. Peterson. 1991. Modeling combustion of alternative fuels in a DI diesel engine using KIVA. Trans. ASAE 33(2): 342-350. (Paper received Outstanding Paper Award from ASAE)

\subsection{IOWA STATE UNIVERSITY-SELECTION OF HERBACEOUS ENERGY CROPS FOR PRODUCTION IN DOUBLE-CROPPING SYSTEMS}

Investigator: I. C. Anderson

Goak:

To (1) compare biomass production from various types of cropping systems, (2) compare soil loss potential associated with cropping systems, (3) measure the quality of the biomass from each system to determine efficiencies of combustion and conversion to chemical energies, and (4) evaluate the economic aspects of the farming systems.

\section{Highlights}

Maximum biomass yields of herbaceous crops tested in screening trials in lowa are summarized in Table 3. Highest yielding crops were sweet sorghum and sorghum $x$ sudangrass.

Table 3. Maximum biomass yields of crops grown in Iowa

\begin{tabular}{lrrrr}
\hline Species & 1988 & 1989 & 1990 & Avg \\
\hline & & & & \\
Alfalfa & 6.1 & 12.9 & 12.2 & 10.4 \\
Reed canarygrass & 5.4 & 10.0 & 11.8 & 9.1 \\
Big bluestem & 6.1 & 8.9 & 11.9 & 9.0 \\
Switchgrass & 8.0 & 8.3 & 13.3 & 9.9 \\
Sweet sorghum & 19.5 & 16.4 & 22.9 & 19.6 \\
Sorghum x sudangrass & 15.7 & 16.4 & 22.8 & 18.3 \\
Corn & 10.8 & 20.9 & 18.5 & 16.7 \\
& & & & \\
\hline
\end{tabular}


Fiber (cell solubles, cellulose, hemicellulose, and lignin) analyses for all samples harvested through 1990 have been completed. Average chemical composition of each crop is shown in Fig. 7. The soil profile below selected plots has been sampled to determine if nitrate leaching has occurred below the plots and if there are differences among the cropping systems. Analyses will begin soon.

Figures 8 and 9 show yields of dry matter, cellulose, hemicellulose, and lignin for 1990 for sweet sorghum and sorghum $\times$ sudangrass. The results show that, during this year of an above normal rainfall during the summer, a dry matter yield advantage for double-cropping winter rye with sorghum occurred only when high nitrogen rates were used. The relative yield advantage from double-cropping was greater for cellulose and hemicellulose than for dry matter because winter rye has higher concentrations of cellulose and hemicellulose than does sorghum.

Intercropping sorghum into alfalfa raised the average yield from that of pure alfalfa $(10.9 \mathrm{Mg} / \mathrm{ha}$ ) to $14.3 \mathrm{Mg} / \mathrm{ha}$ for sorghum $\times$ sorghum system and to $13.7 \mathrm{Mg} / \mathrm{ha}$ for sweet sorghum. Intercropping into reed canarygrass, however, only raised the average yield from that of pure reed canarygrass $(9.4 \mathrm{Mg} / \mathrm{ha})$ to $10.1 \mathrm{Mg} / \mathrm{ha}$ for both sorghum $\times$ sudangrass and sweet sorghum systems.

In addition to production of cellulose and hemicellulose, sweet sorghum produces high yields of sucrose, fructose, and glucose. Total sugar yields of over $6 \mathrm{Mg} / \mathrm{ha}$ can occur, which can be fermented into more than $4000 \mathrm{~L}$ of ethanol per hectare.

Major conclusions from this study are as follows:

1. Alfalfa and sorghum are the least sensitive to drought of the crops evaluated.

2. Double-cropping systems are more sensitive to drought than are the solecropping systems.

3. The annual species evaluated are more productive than the perennial species.

4. Intercropping sorghum into alfalfa can raise yields over those from alfalfa grown alone.

5. Intercropping sorghum into reed canarygrass shows no yield advantage over reed canarygrass grown alone.

6. Double-cropped sorghum requires more nitrogen for maximum yields than sorghum grown alone. 


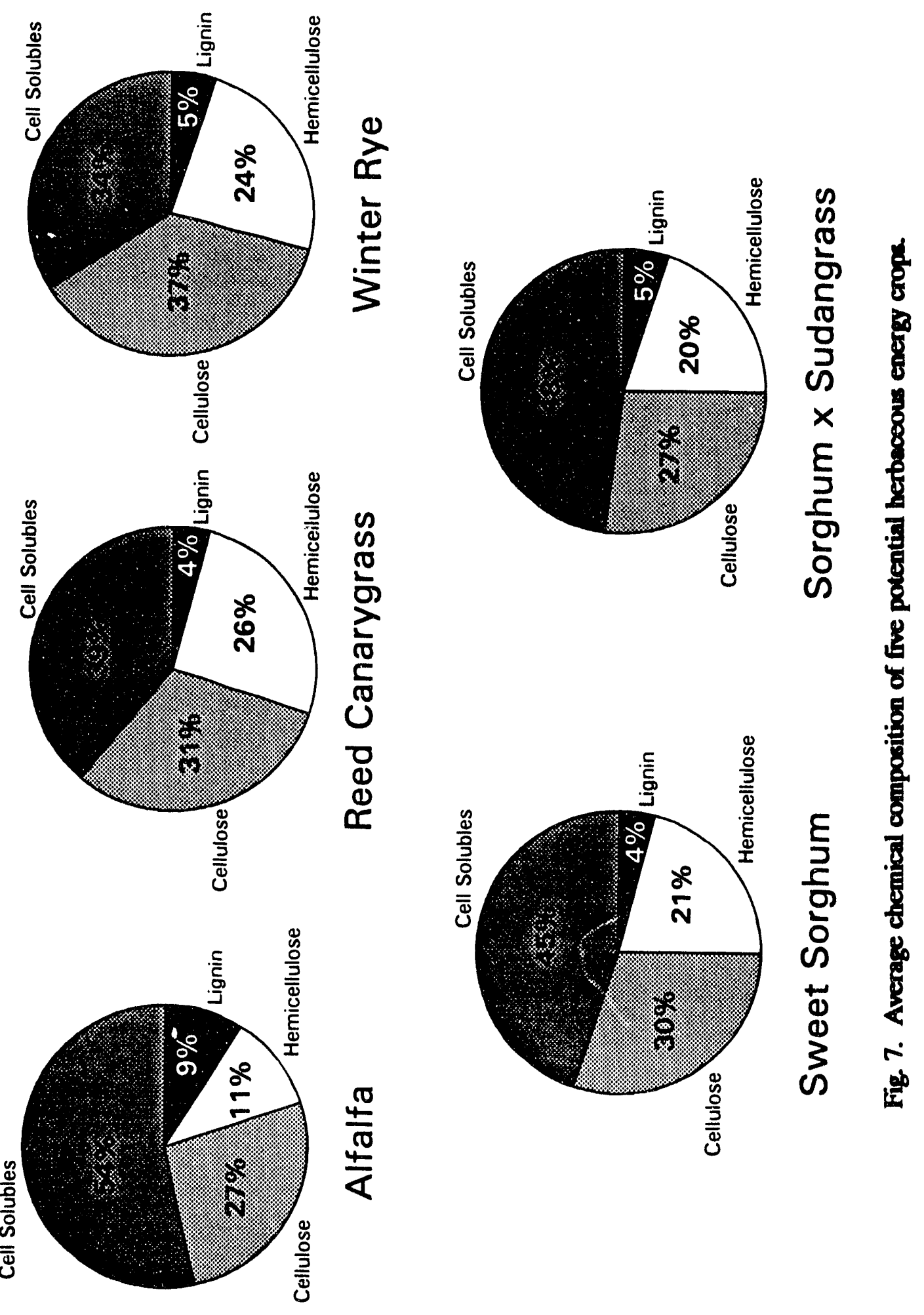



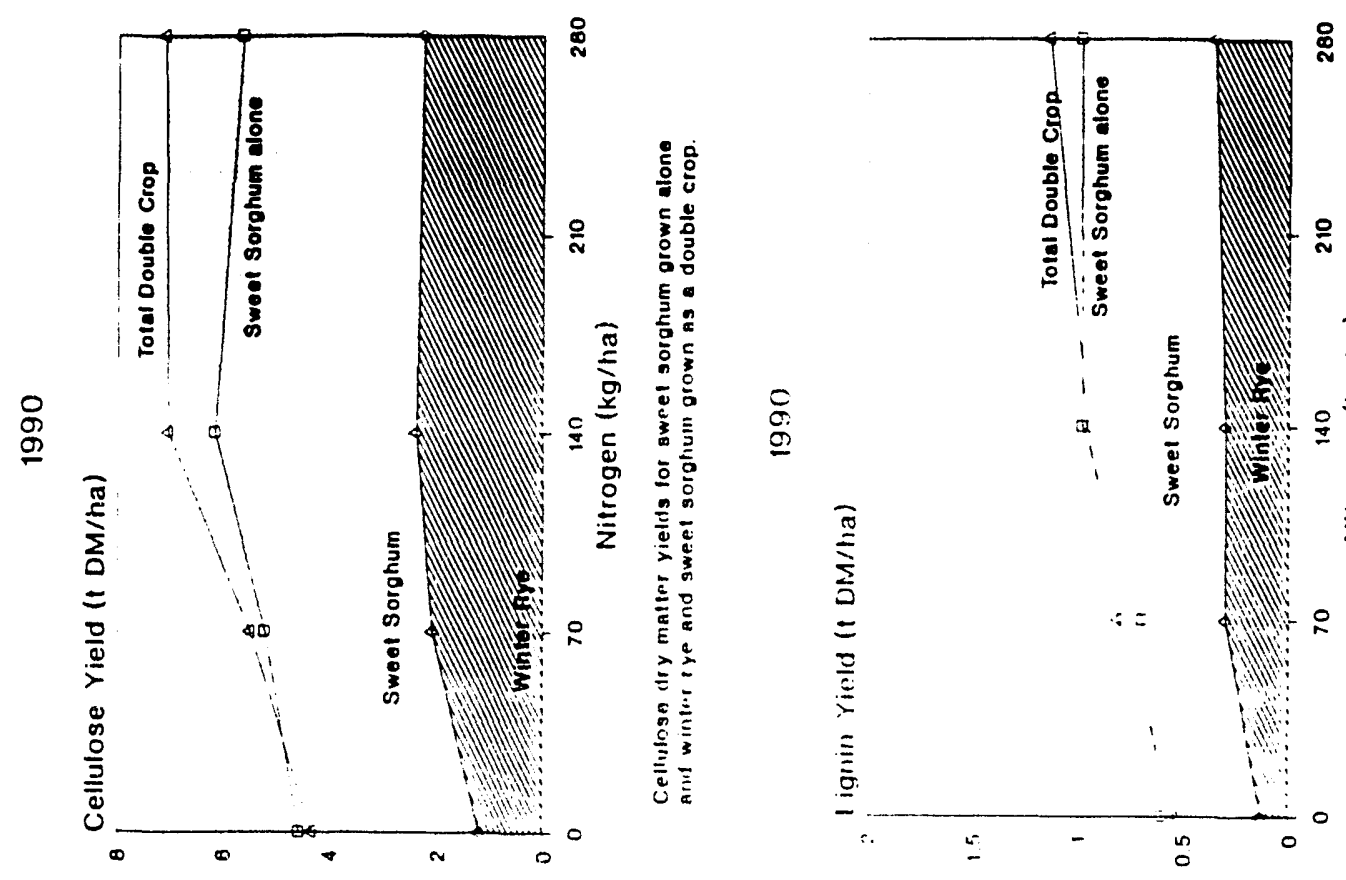

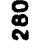
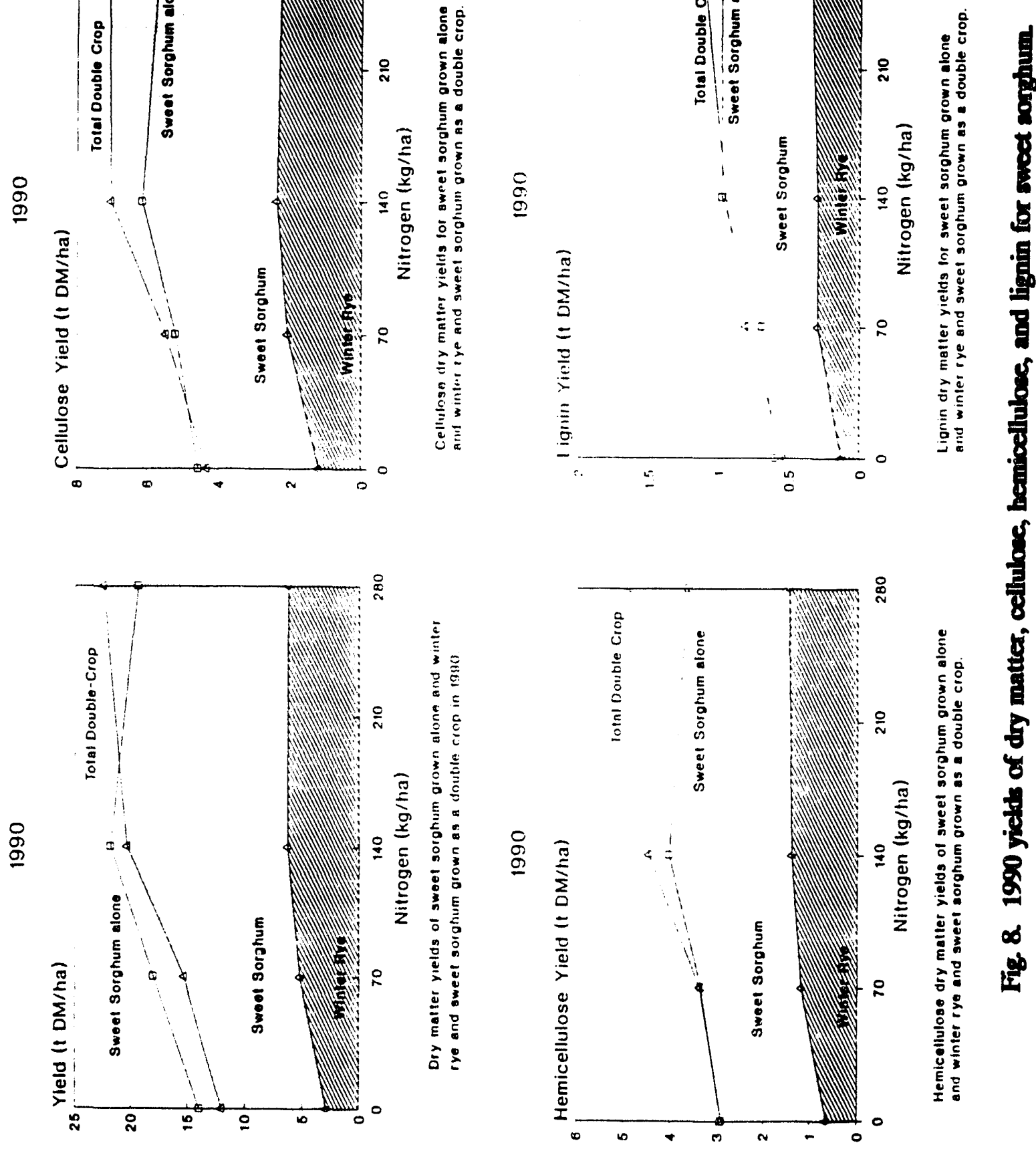

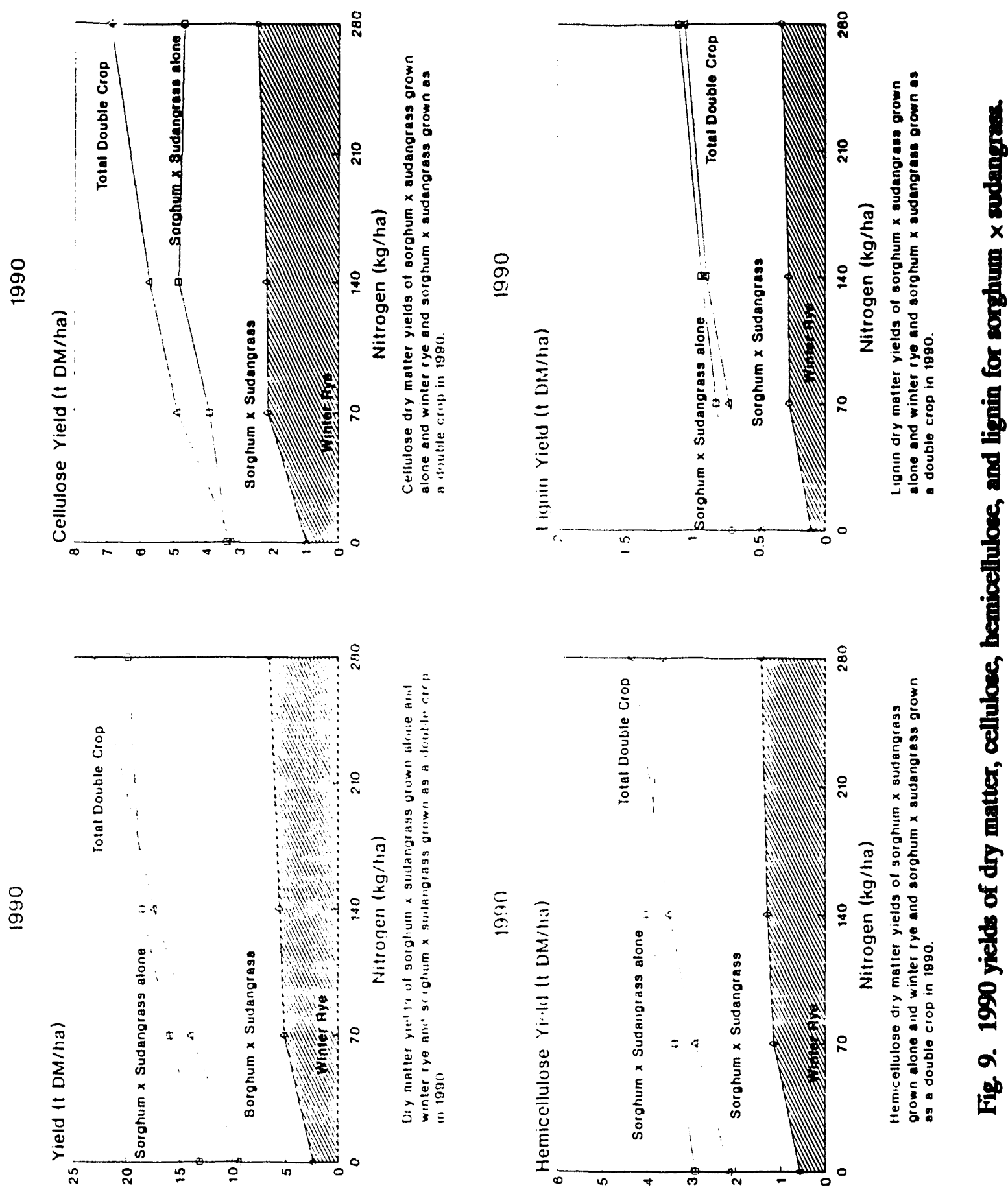
7. With normal precipitation and high nitrogen rates, double-cropped sorghum can out yield sole sorghum by up to $6 \mathrm{Mg}$ ha.

8. Sweet sorghum also can produce over $6 \mathrm{Mg}$ /ha soluble sugars.

\section{Information Discemination}

Anderson, I. C., D. R. Buxton, and P. A. Lawlor. 1991. Yield and chemical composition of perennial grasses and alfalfa grown for maximum biomass. p. 128-132. IN Proc. Amer. Forage Grassl. Conf. 1-4 April. Columbia, Mo. American Forage and Grassland Council, Georgetown, Tex.

\subsection{UNIVERSITY OF KENTUCKY-BIOMASS PRODUCTION BY FESCUE AND SWITCHGRASS ALONE AND IN MIXED SWARDS WTTH LEGUME}

Investigator: $\mathbf{M}$. Collins

Goals

To (1) evaluate biomass productivity and composition of tall fescue (Festuca arundinacea Schreb.) grown alone and with perennial legumes and (2) evaluate biomass productivity and composition of switchgrass (Panicum virgatum) grown alone and with bigflower vetch (Vicia grandiflora).

\section{Highlights}

Productive mixtures of (1) tall fescue (Festuca arundinacea Schreb.) and birdsfoot trefoil (Lotus corniculatus L.) and (2) tall fescue and alfalfa (Medicago sativa L.) were compared with pure grass stands fertilized with 75,150 , or $225 \mathrm{~kg} / \mathrm{ha}$ or left unfertilized. Environmental conditions were favorable during most of the 1991 growing season at this location, and high dry matter yields were produced (Fig. 10). The response to increasing nitrogen fertilization rates continued up to the highest rate applied. This nitrogen fertilization rate $(225 \mathrm{~kg} / \mathrm{ha})$ is above the rate at which tall fescue yields are maximized in many environments. Dry matter yield of nitrogen-fertilized grass stands increased by $30 \mathrm{~kg} /$ ha per kilogram of nitrogen applied. Mixtures of birdsfoot trefoil and tall fescue were very productive and produced yields intermediate between those resulting from the 150 and $225 \mathrm{~kg} / \mathrm{ha}$ nitrogen rates. Approximately one-half of the biomass produced in the birdsfoot trefoil mixtures was tall fescue. Tall fescue mixtures with birdsfoot trefoil 


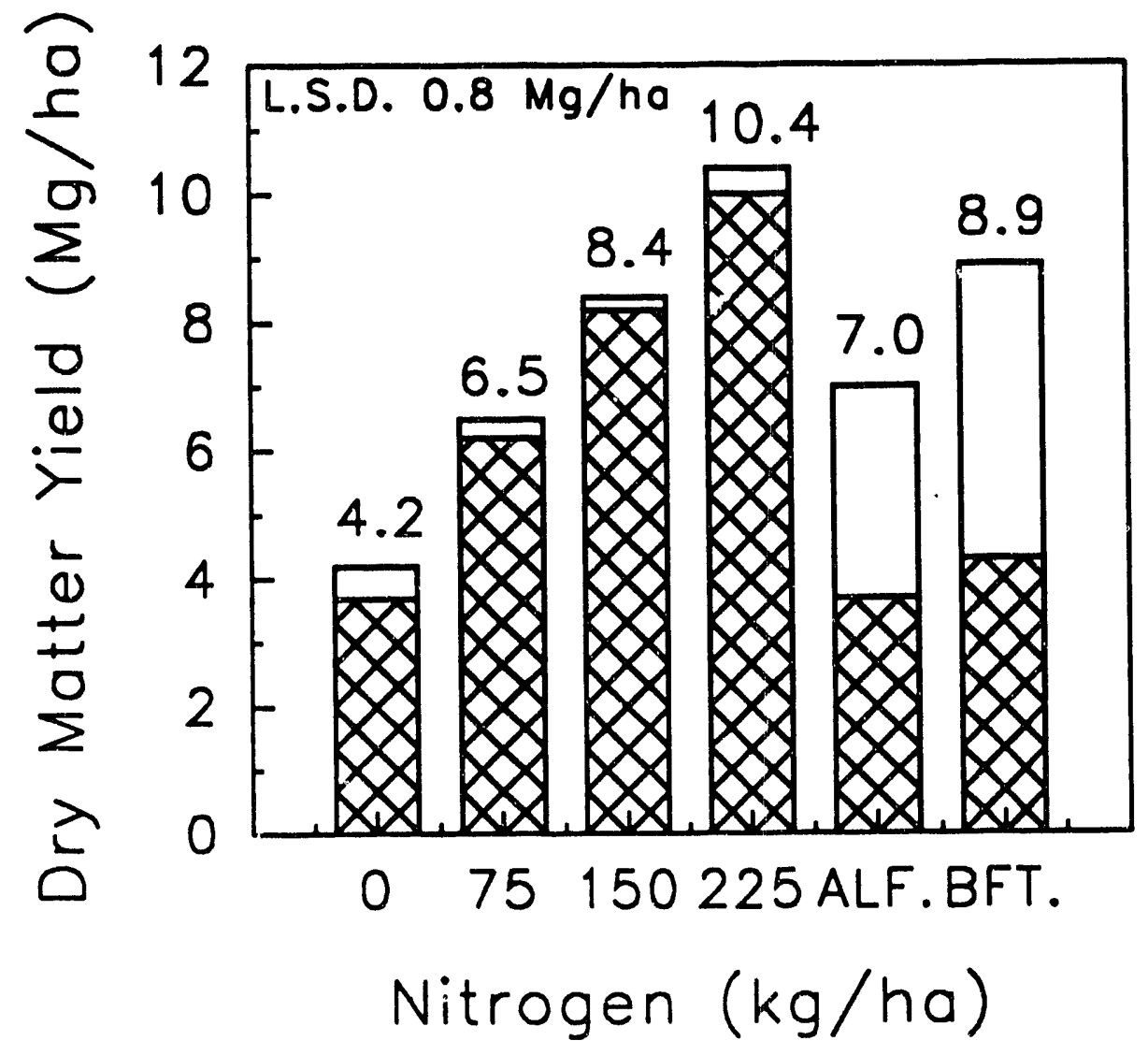

Fig. 10. Dry matter yields of nitrogen-fertilized pure stands and legume mixtures with tall feacue. The hatched portion represents grass yields and the open portion represents weed or legume and weed components. 
produced significantly more dry matter than mixtures with alfalfa. Generally, alfalfa is more productive than birdsfoot trefoil in this environment. In this case, greater stand density of the birdsfoot trefoil appears to contribute to the observed difference in productivity. These results demonstrate that perennial legumes, especially birdsfoot trefoil, are able to produce biomass yields comparable to those of pure stands of tall fescue receiving $225 \mathrm{~kg} / \mathrm{ha}$ of nitrogen fertilization.

\section{Information Dimemination}

Collins, M. 1991. Biomass production by nitrogen fertilized switchgrass monocultures and mixtures with bigflower vetch. Southern Biomass Conference. Baton Rouge, La.

Collins, M. 1991. Biomass production by tall fescue-N and tall fescue-legume mixtures. Biofuels energy conference. September 16-20, 1991. American Society of Agricultural Engineers, Biofuels Feedstock Development Program, and the

Western Area Regional Biofuels Program. University of California, Davis.

\subsection{NORTH DAKOTA STATE UNIVERSITY -EVALUATION OF HERBACEOUS BIOMASS CROPS IN THE NORTHERN GREAT PLAINS}

Investigators: D. W. Meyer, D. O. Erickson, and R. G. Johnson

Goaks

To evaluate the potential of several herbaceous species for biomass production on good and marginal cropland, evaluate the economic feasibility of herbaceous energy crops with typical cropping alternatives in northern Great Plains, and determine the effect of annual crop biomass cropping on subsequent crop yield.

\section{Highlights}

Biomass yields of four annuals and at least six perennials have been obtained at three good, two marginal, and one irrigated soil sites in 1991. Maximum biomass yield was $23.2 \mathrm{Mg} / \mathrm{ha}$ from dryland forage sorghum and $16.1 \mathrm{Mg} / \mathrm{ha}$ from crested wheatgrass (perennial) in 1990; 1991 yields are currently being determined but appear to be lower yielding. Intermediate wheatgrass generally has been the highest yielding perennial during 1989-1990, but switchgrass and reed canarygrass indicated promise with limited observations. Kochia continues to perform well on drought-stressed sites (maximum 
biomass yield of $20.2 \mathrm{Mg}$ /ha on annually seeded plots). Establishment of kochia was a problem in limiting 1991 results. Maturity was a major yield factor in a preliminary experiment in 1990. Allelopathic effects were a major yield limiting factor in volunteering kochia. Growing-season precipitation explained about half of the variation in biomass yields across a precipitation gradient in 1990, but little in 1989. A preliminary economic feasibility of biomass cropping is under way and should be available in early 1992.

Information Disemination

Meyer, D. W., D. E. Lippert, D. 0. Erickson, and R. G. Johnson. 1991. Evaluation of Herbaceous Biomass Crops in the Northern Great Plains. Unpublished Annual Report submitted to Oak Ridge National Laboratory. North Dakota State University, Fargo, N.D.

Meyer, D.W., D.E. Lippert, W.E. Norby, and D.O. Erickson. 1991. Evaluation of Herbaceous Biomass Crops in North Dakota. p. 153. IN Agronomy Abstracts. ASA, Madison, Wis.

Meyer, D. W., W. E. Norby, D. O. Erickson, and R. G. Johnson. 1991. Evaluation of herbaceous Biomass Crops in the Northern Great Plains. Biofuels Energy Conference, 16-20 Sept. 1991. Davis, Calif.

\subsection{PURDUE UNIVERSITY-EVALUATION OF POTENTIAL HERBACEOUS BIOMASS CROPS ON MARGINAL LANDS}

Investigator: $\mathrm{K}$. D. Johnson

Goak

To evaluate the agronomic and economic feasibility of a variety of production and storage systems for herbaceous biomass crops.

\section{Highlights}

Screening of hybrid forage sorghums that were high yielding in Indiana, Kansas, and Oklahoma evaluation trials were included in a 1990 study conducted at the Throckmorton and Southern Indiana Purdue Agricultural Centers (Throckmorton-PAC and SIPAC, respectively). Genotype and population were in a factorial combination 
design. The densities of targeted plant populations were $4.3 \times 104$ and $2.58 \times 105$ plants per hectare. 'Dekalb 711' was the corn hybrid selected for yield comparison, and $200 \mathrm{~kg} / \mathrm{ha}$ of nitrogen was applied on all plots.

Total biomass and grain yields were higher at Throckmorton-PAC than at SIPAC (data not shown). Undoubtedly, much of the reduced yield at SIPAC was the result of late planting because of wet soil conditions. Top-producing genotypes included 'Pioneer 931,' 'Vartan 3192,' 'Northrup King Sucrosorgo 506,' 'Grassl,' and 'Vartan 3' (Table 4). Greatest biomass production did not come from genotypes producing the most grain. A tall-growing corn hybrid, 'Dekalb 711,' yielded 23.95 and $22.26 \mathrm{Mg} / \mathrm{ha}$ total biomass at Throckmorton-PAC and SIPAC, respectively. Corn grain accounted for $\mathbf{4 0 . 7}$ and $\mathbf{5 2 . 2 \%}$ of the total dry matter production at Throckmorton-PAC and SIPAC, respectively.

The tallest growing cultivar, 'Vartan 2319,' was only intermediate in total biomass yield (Table 4). Lodging resistance is critical for top yields. All high-yielding cultivars except 'Grassl' had an average lodging score greater than four (Table 4). The lower plant population, in general, did reduce lodging, although for 'Pioneer 811F, 'Vartan 3,' and 'Vartan 2319' the higher plant population had no effect on lodging or there was an arithmetically higher lodging score. 'Grassl,' a high-yielding genotype, had substantial reduction in lodging at the lower plant population.

A sixfold greater plant population resulted in 2.25 and 1.78 greater tillers per square meter at Throckmorton-PAC and SIPAC, respectively. An increase in plant population, however, did not improve biomass yield. Yield at the lower plant population was maintained by individual tillers accumulating more dry matter than tillers at the higher plant population. Tiller number per square meter is not the key factor in determining biomass yield. Highest yielding genotypes had a range of 20.7 and 13.1 tillers per square meter.

\section{Information Diseemination}

None 
Table 4. Mean total biomass yield, grain yield, height, and lodging score of sorghum planted at two sites in 1990

\begin{tabular}{|c|c|c|c|c|c|}
\hline \multirow[b]{3}{*}{ Genotype } & \multirow{2}{*}{\multicolumn{2}{|c|}{$\begin{array}{r}\text { Yield } \\
\text { (mg/ha) }\end{array}$}} & \multirow{3}{*}{$\begin{array}{c}\text { Height } \\
\text { (m }\end{array}$} & \multicolumn{2}{|c|}{ Lodging ${ }^{a b}$} \\
\hline & & & & \multirow{2}{*}{$\begin{array}{l}\text { Site } A^{c} \\
4.3 \times 10^{4}\end{array}$} & \multirow{2}{*}{$\begin{array}{l}\text { Site } \mathrm{B}^{d} \\
2.6 \times 10^{5}\end{array}$} \\
\hline & Total & Grain & & & \\
\hline Pioneer 931 & 24.67 & 2.02 & 4.64 & 4.92 & 4.83 \\
\hline Vartan 3192 & 24.08 & 0.10 & 4.37 & 4.50 & 4.17 \\
\hline NK Sucrosorgo 506 & 22.65 & 1.48 & 4.36 & 5.00 & 4.92 \\
\hline Grassl & 21.69 & 0.28 & 3.69 & 4.22 & 3.08 \\
\hline Vartan 3 & 20.60 & 0.01 & 4.21 & 4.67 & 4.88 \\
\hline Funks G 1990 & 19.71 & $\mathbf{0}$ & 3.74 & 5.00 & 4.92 \\
\hline Vartan 2319 & 19.69 & .01 & 5.08 & 4.00 & 4.17 \\
\hline Pioneer 811F & 19.21 & $\mathbf{0}$ & 3.38 & 5.00 & 5.00 \\
\hline Golden Harvest H-58 & 18.65 & 3.07 & 3.32 & 3.83 & 3.67 \\
\hline Meridian $81 \mathrm{E}$ & 18.28 & 1.11 & 3.68 & 4.22 & 3.67 \\
\hline Asgrow Titan $\mathbf{R}$ & 17.84 & 5.30 & 2.78 & 3.00 & 2.00 \\
\hline Taylor-Evans Milkmaker & 17.71 & 4.14 & 3.04 & 2.08 & 1.67 \\
\hline DeKalb FS25E & 17.48 & 4.09 & 3.00 & 4.33 & 2.42 \\
\hline Casterline Silo Plus & 16.99 & 4.29 & 2.91 & 2.00 & 1.50 \\
\hline Taylor-Evans Silomaker & 16.95 & 5.49 & 2.58 & 3.58 & 1.00 \\
\hline Garrison Seed Sile-All & 16.51 & 4.78 & 2.96 & 2.08 & 1.50 \\
\hline $\mathrm{NC}^{+} 965$ & 16.46 & 2.68 & 3.29 & 3.58 & 3.17 \\
\hline PAG FS466 & 16.37 & 3.96 & 2.47 & 4.08 & 2.92 \\
\hline BLSD $^{6}$ & 4.39 & 2.99 & 0.32 & & \\
\hline
\end{tabular}

${ }^{a}$ Main effect of population significant at $P=0.06$.

${ }^{b_{1}}=$ flat; 5 = erect.

${ }^{c}$ Population density $=4.3 \times 10^{4}$ plants per hectare.

${ }^{d}$ Population density $=2.6 \times 10^{5}$ planats per hectare.

'Bayes least significant difference ( $\underline{P}$ approximatcly $=0.05)$. 


\subsection{VIRGINIA POLYTECHNIC INSTITUTE AND STATE UNIVERSITY-PERENNIAL SPECIES FOR OPTIMUM PRODUCTION OF HERBACEOUS BIOMASS IN THE PIEDMONT}

Investigators: D. J. Parrish, D. D. Wolf, W. L. Daniels, J. S. Cundiff, and D. H. Vaughan Goak

To investigate eight herbaceous biomass candidates on marginal Piedmont sites and seek ways to optimize economic production of the most promising candidate(s).

\section{Highlights}

Virginia Tech has completed a 5-year screening study of eight herbaceous biomass species. Switchgrass was the most productive of the candidate species studied. Average yields for that warm-season grass when grown on marginal agricultural sites ranged from 8 to $16 \mathrm{Mg}$ ha during the years following establishment. Switchgrass yields did not appear to be as dependent on growing season rainfall as were yields of most of the other crops. Economic and erosional analyses showed distinct differences among the candidate species; culture of an annual species resulted in significantly higher soil losses than with perennial species, and switchgrass was shown to be superior both for economic and erosional considerations.

In FY 1991, we have continued studying management of switchgrass to optimize its biomass production. In particular, we have looked more closely at $\mathrm{N}$ fertilization requirements and cutting schedules. We applied 0,50 , or $100 \mathrm{~kg} \mathrm{~N} /$ ha to plots of switchgrass grown at three different locations. The switchgrass was harvested in late August or early November. As part of this work, we have also considered the potential of winter-annual legumes as cover crops that can reduce erosion and provide $\mathrm{N}$ to the next season's switchgrass. We planted crimson clover, hairy vetch, or arrowleaf clover into plots of switchgrass that received no added $\mathrm{N}$ and were cut in August. The legumes were killed by 2,4-D applications in mid-May.

At one of the three locations, there was no yield response to added N. Averaged over all three sites, switchgrass appeared to reach its $\mathrm{N}$-limited biomass maximum at about $50 \mathrm{~kg} / \mathrm{ha}$. In 1990, a crimson clover cover crop boosted switchgrass yields, but arrowleaf clover was without effect-probably because of winter-kill. Hairy vetch, on the other hand, reduced switchgrass yields, apparently because of its aggressive, smothering growth during 
the time when switchgrass was beginning to emerge. Delaying harvest past the first of September had no positive benefit in 1990.

Table 5. Yiekts (in Mg/ha) of switchgrass grown at three locations in the Virginia Piedmont in 1990 as affected by $\mathbf{N}$ fertilization, date of cutting, or winter-annual legume cover crop. Each yield value is a mean of 12 plots (three sites $x$ four repetitions

\begin{tabular}{|c|c|c|c|}
\hline \multicolumn{2}{|c|}{ Preharvest treatments } & \multicolumn{2}{|c|}{ Cutting date } \\
\hline $\begin{array}{c}\mathrm{N} \\
\text { (hg/ha) }\end{array}$ & Cover Crop & 29-30 Aug & 2 Nov \\
\hline $\mathbf{0}$ & None & 8.4 & 8.3 \\
\hline 50 & None & 11.0 & 9.5 \\
\hline 100 & None & 11.7 & 10.2 \\
\hline 0 & Crimson clover & 9.6 & \\
\hline $\mathbf{0}$ & Hairy vetch & 6.2 & \\
\hline $\mathbf{0}$ & Arrowleaf cluver & 7.6 & \\
\hline
\end{tabular}

This management study will be concluded in fall 1991, when a single, late harvest will be made. Those yield data should provide information on whether the cutting regimes have residual effects.

\section{Information Disemination}

Nagle, S. M., D. J. Parrish, D. D. Wolf, and W. L. Daniels. 1990. Establishment and persistence of seven perennial herbaceous species in the Piedmont. Agronomy Abstr. 1990: 153.

Parrish, D. J., D. D. Wolf, W. L. Daniels, and S. M. Nagle. 1990. A 5-year screening study of herbaceous biomass species in the Piedmont. Agron. Abstr. 1990: 191.

Sullivan, P., D. D. Wolf, D. J. Parrish, and S. M. Nagle. 1990. Low-input management of switchgrass grown for biomass. Agron. Abstr. 1990: 159. 


\section{ENVIRONMENTAL RESEARCH AND ANALYSIS}

Dwindling clean coal supplies, the requirements of the Clean Air Act, and concern over greenhouse gas emissions have drastically increased the need for quantifying the environmental implications of lignocellulosic energy crops. If millions of acres are converted from agriculture to energy crops, habitat changes and chemical emissions are also of significant national concern.

In response to these needs, BFDP has greatly expanded its efforts in environmental evaluations. These activities have three major emphases. The first involves land-use analyses in connection with geographic information system (GIS) resource data and economic modeling to determine specific resources that would most likely be affected by energy crop deployment. These assessments can help researchers evaluate the degree to which policy affects land use, environment, agriculture, energy, forestry, and energy crops. Evaluations of this kind are being completed for six locations in the United States.

The second major emphasis involves the quantification of environmental effects from energy crops based on existing literature, various agricultural analogies, and theories on such topics as chemical transport and fate, habitat qualities and biodiversity, and carbon cycling. These efforts are enabling researchers to set clearer priorities related to the third major environmental emphasis.

The third emphasis is on the collection of new data from energy crops, their analogues, and control environments. Studies have already examined a number of related aspects, including small mammais, carbon, soil bacteria, and nitrogen cycling. Further evaluations will address avian populations, erosion, chemical fates, and gas exchange. The entire environmental effort incorporates the interests and capabilities of a complex network of research groups including the USDA, the USDA Forest Service, other national laboratories, conservation groups, utilities, and academic institutions. Summaries of environmental analyses conducted by ORNL staff follow. 


\subsection{OAK RIDGE NATIONAL LABORATORY-EVALUATING THE LAND FOR BIOMASS ENERGY CROP PRODUCTION IN THE UNITED STATES}

Investigator: R. L. Graham

Goals

This project takes a two-phase approach in researching the potential of energy crops in the United States. The first phase examines the issues from a national perspective and attempts to define on a national scale the acreage and location of land that could grow biomass energy crops and the expected yields. The second phase addresses the economic, social, and environmental constraints to energy crop development through the use of site-specific case studies of potential biomass energy production facilities.

\section{Highlights}

The first phase is almost completed. The USDA's 1982 National Resource Inventory (NRI) data base was used to characterize the potential land base for biomass energy crops. This data base contains $\sim 800,000$ geographically specific point observations about current land use and agricultural capability on nonfederal lands in the United States. Each of these observations has an extension factor that allows calculation of the acreage of land associated with an observation. The sum of all point acreages is the total area of nonfederal land in the United States. Researchers in the energy crop production were queried and an empirical model (look-up table) developed to predict potential energy crop yield on the basis of site attributes found in the NRI. With the use of this model, the NRI was queried to determine the acreage, potential biomass yield, and location of land suitable for biomass energy crops.

In the coterminous United States, 392 million acres are capable of growing biomass energy crops. Of this total $78 \%$ is currently used for growing crops, and $13 \%$ is used as pasture. The remaining $9 \%$ comes from a variety of other land uses. SRWCs with expected annual yields of 5 tons or more of dry standing woody biomass per acre could be grown on 225 million of these acres by using current best management practices. Herbaceous energy crops (HEC) with similar expected yields could be grown on 324 million acres. Most of the suitable land for growing SRWC lies in the north central region of the United States (Illinois, Indiana, Iowa, Kansas, Michigan, Minnesota, Missouri, Nebraska, North Dakota, South Dakota, and Wisconsin). In this region, 817 
million tons of dry woody biomass could be produced annually on 128 million acres. This region is also the most likely location for HEC production, with 167 million suitable acres potentially yielding 1338 million dry tons of herbaceous biomass per year. The south central region (Alabama, Arkansas, Louisiana, Mississippi, Oklahoma, Tennessee, and Texas) contains the second-largest amount of acreage suitable for woody and herbaceous energy crops.

Land that has severe restrictions for growing conventional annual crops but is suitable for energy crops may be the most likely land for conversion to energy crops. There are 37 million acres of such land suitable for SRWC and 134 million acres for HEC. If planted to energy crops, these acreages could yield 229 million tons of dry woody biomass or 787 million tons of herbaceous biomass each year. If current biomass energy conversion technologies were employed, this amount of woody biomass could annually produce -15 billion gallons of ethanol (10\% of current U.S. gasoline consumption) or 296 million megawatt-hours of electricity ( $11 \%$ of current U.S. electric power consumption). This amount of herbaceous biomass could annually produce $\sim 45$ billion gallons of ethanol or 620 million megawatt-hours of electricity.

\subsection{OAK RIDGE NATIONAL LABORATORY-ENVIRONMENTAL EFFECTS OF BIOFUELS FEEDSTOCK PRODUCTION}

Investigators: J. W. Ranney and L. L. Wright

Goak

Because the production of biomass for energy may involve tens of millions of acres, environmental information is needed on the shanges and conditions generated by this new land use. Little information specific to energy crops is available.

\section{Highlights}

In 1991, efforts were taken to identify important environmental issues, scope preliminary data, and plan an environmental monitoring program on biomass energy crops for FY 1992. The major issues fall into two groups: those concerning environmental effects and those concerning environmental policy. The environmental-effects issues involve greenhouse gas exchange, biodiversity, sustainability, and air quality. More specifically they involve $\mathrm{CO}_{2}$; habitat quality, especially for bottomland and wetlands; measures of species composition; the use and fate of chemicals; erosion; general landscape 
changes; and full-cycle (biomass production, conversion, and use) biofuels emissions for ethanol and electricity, especially compared with emissions from reformulated gasoline and coal (e.g., $\mathrm{CO}_{2}, \mathrm{CO}$, nitrogen oxides, sulfur oxides, methane, and volatile organic compounds).

Environmental groups are interested in influencing policies to correct past forestry and agricultural concerns. Forest clearcutting, riparian zone and wetland protection, wilderness expansion, chemical controls, general wildlife habitat improvement, and erosion control are some of the issues. Other interests include specific full-cycle gas balances of biofuels compared with fossil fuel and agricultural policy on the use of set-aside or conservation land. Credits, payments, regulations, and monitoring requirements, which will affect both the environmental effects and competitiveness of energy crops, will all affect energy crop production.

The first energy crop environmental data are favorable with respect to habitat improvement and gas emissions and are mixed on erosion and chemical use. Habitats most vulnerable to possible negative effects of energy crops are still being defined but are believed to be privately owned bottomlands and wetlands. Environmental monitoring plans call for several workshops, coordination with the EPA and environmental groups, and the use of many existing experimental and scale-up sites around the country to develop a network for environmental data collection.

\subsection{OAK RIDGE NATIONAL LABORATORY-BIOMASS ENERGY STRATEGIES FOR CARBON DIOXIDE MITIGATION IN THE UNITED STATES}

Investigators: L. L. Wright, R. L. Graham, L. L. Mann, R. D. Perlack, J. W. Ranney, A. F. Turhollow, D. Waddle, and L. L. Wright, Oak Ridge National I aboratory; William Hohenstein, Bruce Company; Don Stevens, Cascade Research, Inc.

\section{Goak}

To develop background information and preliminary strategy options for using biomass energy technologies to reduce $\mathrm{CO}_{2}$ emissions in the United States.

\section{Highlights}

Background information papers have been prepared on six topics: (1) status of production technology of herbaceous and wood energy crops; (2) regional analysis of land suitability for biomass energy crops in the United States; (3) regional analysis of land 
changes; and full-cycle (biomass production, conversion, and use) biofuels emissions for ethanol and electricity, especially compared with emissions from reformulated gasoline and coal (e.g., $\mathrm{CO}_{2}, \mathrm{CO}$, nitrogen oxides, sulfur oxides, methane, and volatile organic compounds).

Environmental groups are interested in influencing policies to correct past forestry and agricultural concerns. Forest clearcutting, riparian zone and wetland protection, wilderness expansion, chemical controls, general wildlife habitat improvement, and erosion control are some of the issues. Other interests include specific full-cycle gas balances of biofuels compared with fossil fuel and agricultural policy on the use of set-aside or conservation land. Credits, payments, regulations, and monitoring requirements, which will affect both the environmental effects and competitiveness of energy crops, will all affect energy crop production.

The first energy crop environmental data are favorable with respect to habitat improvement and gas emissions and are mixed on erosion and chemical use. Habitats most vulnerable to possible negative effects of energy crops are still being defined but are believed to be privately owned bottomlands and wetlands. Environmental monitoring plans call for several workshops, coordination with the EPA and environmental groups, and the use of many existing experimental and scale-up sites around the country to develop a network for environmental data collection.

\subsection{OAK RIDGE NATIONAL LABORATORY-BIOMASS ENERGY STRATEGIES FOR CARBON DIOXIDE MITIGATION IN THE UNITED STATES}

Investigators: L. L. Wright, R. L. Graham, L. L. Mann, R. D. Perlack, J. W. Ranney, A. F. Turhollow, D. Waddle, and L. L. Wright, Oak Ridge National Laboratory; William Hohenstein, Bruce Company; Don Stevens, Cascade Research, Inc.

\section{Goaks}

To develop background information and preliminary strategy options for using biomass energy technologies to reduce $\mathrm{CO}_{2}$ emissions in the United States.

\section{Highlights}

Background information papers have been prepared on six topics: (1) status of production technology of herbaceous and wood energy crops; (2) regional analysis of land suitability for biomass energy crops in the United States; (3) regional analysis of land 
availability as determined by consideration of economic constraints; (4) status of conversion technologies suitable for utilization of biomass energy crops; (5) summary of potential environmental issues associated with production of woody and herbaceous energy crops; and (6) summary of available information on current and projected energy use, needs, and costs for several regions of the United States. These topics will be integrated in a summary paper outlining national research and policy options for increasing the use of biomass energy. Additionally, a workshop was planned as a means of gathering information and recommendations from a cross section of government and private sector groups.

The first drafts of all papers (except the summary chapter) are finished and are being technically reviewed. The goal is to produce papers for publication in the open literature. The workshop was conducted in early November 1990 . The 40 attendees included representatives from ORNL, EPA, DOE, USDA, NREL, the Tennessee Valley Authority, the Audubon Society, paper products industries, power companies, universities, and small business. BFDP staff presented the initial session, which provided an overview of technological and environmental considerations with regard to energy crop production. Working groups drew up lists of constraints and solutions associated with commercializing energy crop production and with generating electricity and producing liquid fuels from biomass. General group discussions provided recommendations on priorities for research and development (R\&D) and policy changes required to stimulate commercialization of biomass energy in the United States. There was a general consensus that demonstrations were needed to assure the private sector of the feasibility of biomass energy technologies. Other recommendations included (1) the continuation of R\&D on production and conversion technologies, (2) the application of siting studies to characterize infrastructure requirements and potential environmental impacts, (3) the use of economic and risk assessments, and (4) the implementation of more aggressive technology transfer about the feasibility and benefits of biomass technologies.

\section{ECONOMIC ANALYSIS AND INTEGRATION}

The goal of the Economic Analysis and Integration component is to ensure that all linkages affecting the overall viability of biomass-based fuel cycles are understood and 
considered in program research and planning. This component includes the translation of research results to projections of estimated biomass production costs. Because low production costs alone will not ensure the economic viability of energy crops, this component also includes investigations of the economic consequences of growing energy crops, both for the producing farmer and the agricultural sector as a whole. This year the program began a modeling effort to incorporate farm-level constraints into a national farm sector model.

Economic Analysis and Integration staff are also responsible for coordinating the input on biomass production systems needed in DOE and NREL planning and analysis efforts.

\subsection{OAK RIDGE NATIONAL LABORATORY-OPTIMUM NITROGEN NUTRITION IN SHORT-ROTATION SYCAMORE PLANTATIONS}

Investigators: H. Van Miegroet and R. J. Norby

\section{Goaks}

To evaluate the optimum nitrogen fertilization regime in a short-rotation American sycamore (Platanus occidentalis) plantation, with optimum defined in various ways depending on management objectives. The several definitions of the optimum regime include maximum fertilizer recovery, maximum biomass production, or maximum gain in production relative to the costs. The costs of nitrogen fertilization that are considered include environmental costs (nitrate leaching into groundwater) and biological costs (altered stress resistance).

\section{Highlights}

Highest tree growth initially occurred after a single heavy dose $(450 \mathrm{~kg} / \mathrm{ha})$ was applied in 1989, but this treatment effect was lost in 1990. By the second year of fertilization, tree growth and biomass production had become highest with the addition of increasing amounts of fertilizer $(50,150$, and $250 \mathrm{~kg} / \mathrm{ha}$ in 1989,1990 , and 1991 , respectively). This treatment was considered optimum in terms of yield. The single heavy dose caused elevated nitrate concentrations in the soil water throughout the first treatment year, after which treatment effects on soil water chemistry gradually declined. There were minimal effects on soil water quality when fertilizer was added in small 
repeated doses (three times $50 \mathrm{~kg} / \mathrm{ha}$ every year) or when nitrogen additions increased commensurate with tree growth (annual balloon), indicating maximum nitrogen recovery. Laboratory incubations showed that differences in mineralizable soil nitrogen between treatments could no longer be detected 1 year after fertilizer application. Our study indicates that the longevity of the nitrogen fertilization effect is regulated by annual tree uptake and litterfall return patterns rather than by marked changes in soil nitrogen pools.

\section{Information Discemination}

None

\subsection{TUSKEGEE UNIVERSITY-BIOMASS RESEARCH AND TRAINING PROGRAM}

Investigator: A. Weaver

\section{Goats}

To study various urea nitrogen fertilizer regimes required for optimum tree growth and nutrition in a American sycamore (Platanus occidentalis L.) plantation (consisting of approximately $\mathbf{4 0 0 0}$ trees) for at least 4 years.

\section{Highlights}

A 4-year biomass research and training project was initiated by the Carver Research Foundation of Tuskegee University, Tuskegee, Alabama, to study the effects of various urea nitrogen $(\mathrm{N})$ fertilization regimes on optimum tree growth and nutrition in a short-rotation sycamore (Platanus occidentalis L.) tree plantation. Fertilization regimes during the first year (1988) consisted of (1) a single application of $450 \mathrm{~kg} \mathrm{~N} / \mathrm{ha}$;

(2) annual-balloon application of $50 \mathrm{~kg} \mathrm{~N} / \mathrm{ha}$; (3) annual-even application of $150 \mathrm{~kg} \mathrm{~N} / \mathrm{ha}$;

(4) multiple applications of $50 \mathrm{~kg} \mathrm{~N} / \mathrm{ha}$ each, at 2 month intervals; and (5) control (no nitrogen applications). The second and third years consisted of (1) annual-balloon, $150 \mathrm{~kg}$ $\mathrm{N} / \mathrm{ha}$; (2) annual-even, $150 \mathrm{~kg} \mathrm{~N} / \mathrm{ha}$; (3) multiple applications of $50 \mathrm{~kg} \mathrm{~N} / \mathrm{ha}$ each at 2 month intervals; and (4) control (no nitrogen applications) for 1989 and (1) annual-balloon, $250 \mathrm{~kg} \mathrm{~N} / \mathrm{ha}$; (2) annual-even $150 \mathrm{~kg} \mathrm{~N} / \mathrm{ha}$; (3) multiple applications of 50 $\mathrm{kg} \mathrm{N} / \mathrm{ha}$ each at 2 month intervals; and (4) control (no nitrogen applications) for 1990. 
Sycamore tree physiological responses were evaluated and indicated that increased tree growth (height, diameter, and branch numbers) with nitrogen fertilization was the result of prolongation of photosynthetic activity and leaf longevity. Chlorophyll $a$ and $b$ concentrations were greater in the annual-balloon and annual-even treatments when compared with controls during early summer. However, during autumn (September-October), differences in the concentrations of chlorophyll a, chlorophyll b, and xanthophyll + carotenoids were noted in all the urea nitrogen treatment plots when compared with controls. Annual-balloon, annual-even, and multiple urea nitrogen treatments delayed leaf senescence as assessed by late season phenological observations and prolongation of the photosynthetic pigment concentrations of chlorophyll a, chlorophyll b, and xanthophyll + carotenoids. Neither total leaf protein concentrations nor leaf amino acid concentrations were affected.

Sycamore tree physiological responses before and after seasonal nondestructive harvesting of selected trees were evaluated in April, July, and November 1990. Sycamore tree height, as well as diameter at 10 and $140 \mathrm{~cm}$, were measured in all the urea nitrogen treatment and control plots in April, July, and November. Diameter at 10 and $140 \mathrm{~cm}$ were highest in the urea nitrogen treatment plots (July and November). Main stem numbers were not significantly different. Total branch numbers were highest in all the urea nitrogen treatment plots (July and November). Fresh and dry branch, as well as fresh and dry stem, weights were highest in all the urea nitrogen treatment plots (July and November). Branch and stem percentage moisture contents were highest in all the urea nitrogen treatment plots in April and November. However, the bulk density was highest in the control plots.

\subsection{UNIVERSITY OF TENNESSEE INSTTTUTE OF AGRICULTURE-AN EVALUATION OF GRAIN AND/OR BIOMASS-ORIENTED CROPPING SYSTEMS}

Investigator: B. C. English

Goak

To develop and apply a modeling system capable of evaluating the economic potential of several management systems for production of herbaceous biomass crops vs alternative systems in different areas of the eastern United States. 


\section{Highlights}

This project was completed in early April. Fourteen representative farms were developed for the F.L.A.R.E. modeling system. Farm locations range from the Plain states of Nebraska and Kansas to the southeast states of Georgia, Alabama, and Tennessee to the Corn Belt state of Iowa. Several analyses have been conducted. A break-even analysis on switchgrass has been conducted. Regional cost of production estimates for switchgrass, sorghum for biomass, and napier grass have been revised with additional plot data information. Erosion estimates along with the methodology to estimate the erosion for biomass species were developed.

The F.L.A.R.E. modeling system was applied to model the production of switchgrass on three representative farms in the Southeast. Results indicated that erosion was likely to be reduced more by the diversion of cropland to permanent vegetative cover on farms similar to the more highly erodible West Tennessee farms than on the less erodible Tift County, Georgia, farm. Equivalent reductions in erosion rates resulted from enrolling highly erodible cropland in the Conservation Reserve Program (CRI) and from production of switchgrass as a biomass energy crop. Both switchgrass and CRP farm plans resulted in decreased net returns from the base plan, although the biomass farm plans were in general more profitable than the CRP plans. Levels of government involvement could be reduced while maintaining current erosion rates if producers were permitted to produce a biomass crop for sale on land now enrolled in CRP.

\section{Information Dissemination}

English, B. C., R. R. Alexander, K. H. Loewen, S. A. Coady, G. V. Cole, and R. Goodman. 1991. Development of a farm-firm modeling system for evaluation of herbaceous energy crops. ORNL/Sub/88-SC616/2. Oak Ridge National Laboratory, Oak Ridge, Tenn. 37831. 


\subsection{UNIVERSITY OF TENNESSEE INSTITUTE OF AGRICULTURE-AN EVALUATION OF THE HERBACEOUS BIOMASS POTENTIAL IN THE EASTERN UNITED STATES}

Investigator: B. C. English

\section{Goals}

The primary objective of this project is to evaluate herbaceous biomass potential in the eastern United States with regard to the agricultural sector. This appraisal will include estimates on environmental impacts as well as extimates on economic feasibility on a regional basis.

\subsection{UNIVERSITY OF TENNESSEE INSTITUTE OF AGRICULTURE-AN ECONOMIC AND TECHNICAL ANALYSIS OF SELECTED ISSUES RELATED TO ENERGY CROP PRODUCTION}

Investigator: B. C. English

Goaks

Currently, there are three objectives for this project: (1) estimation of costs of biofuel production from selected biomass crops grown in different production zones of the United States; (2) estimation of energy invested in pesticides and chemicals used in agricultural production; and (3) evaluation of the environmental impact on soil of growing herbaceous energy crops on Iowa farms.

\section{Highlights}

Objective No. 1-The previous production cost estimates of various biomass crops were updated to reflect the increased knowledge gained from the ongoing plot studies. Preliminary estimates of transportation costs and processing costs were compiled from secondary sources. Results show that two herbaceous biomass species from the Midwest and Southeast are found to have lower feedstock costs, with the Midwest region seemingly having the edge in overall comparative advantage. Transportation costs at present will not be a large component of the costs but could be in the future if energy price increases are larger than other costs.

Objective No. 2-Most large-scale fertilizer plants have undergone technological improvement during the early to mid-1980s. As a result, the unit energy requirement 
during production of nitrogen fertilizer has shown a sizable reduction when compared with the current estimates available in the literature. Report writing is under way.

Objective No. 3 -Analysis of switchgrass and sorghum cropping systems on two Iowa farms has been completed. Findings indicate that while sorghum for biomass appears to be more economical, it is also more erosive than switchgrass. However, including a rye cover crop and harvesting it for biomass significantly reduces erosion from the sorghum.

\section{Information Dissemination}

English, B. C., and M. G. Bhat. Economic and environmental aspects of producing selected energy crops. Paper presented at the American Agricultural Economics Association Annual Meeting, Manhattan, Kansas, August 1991.

Bhat, M. G., B. C. English, and A. Turhollow. Biofuels from energy crops: Economic and environmental impacts. Poster presented at the American Agricultural Economics Association Annual Meeting, Manhattan, Kansas, August 1991.

Bhat, M. G., and B. C. English. Regional costs of biofuel production. Poster presented at the Biofuels Feedstock Development Program's (BFDP) Annual Workshop, Davis, California, September 1991.

\section{Highlights}

The project began in May and, to date, efforts have been involved developing a framework to add biomass crops to the model, getting the model running at The University of Tennessee, and hiring staff.

\section{TOTAL ENERGY CYCLE ANALYSIS}

Participation in an effort to analyze the total energy cycle was an additional task taken on by BFDP in response to a request from the office of Michael Davis, Assistant Secretary for Conservation and Renewables. ORNL's role was to analyze total emissions from the production, harvest, storage, and delivery of energy crops. This analysis was performed in concert with NREL and Pacific Northwest Laboratories, who addressed conversion and system integratio issues, respectively.

The participants jointly decided to tackle the problem by looking at site-specific land use and environmental effects at five specific sites located in five different regions of the 
United States: Peoria, Illinois (Midwest); Lincoln, Nebraska (Great Plains); Tifton, Georgia (Southeast); Rochester, New York (Northeast); and Portland, Oregon (Pacific Northwest). The NRI data base was used to develop information on land characteristics and uses and erosion potential for each site. On the basis of research experience of BFDP, staff developed plausible scenarios for energy crop types, management strategies, and potential yields. From these scenarios, estimates were made of biomass production, land-use changes, chemical use, and fuel use. Literature reviews and personal contact with various experts were used to assist us in estimating air and water emissions.

This type of site-specific analysis of land distribution and use provided insights into energy crop requirements and transportation requirements. For instance, staff oxiginally assumed that $100 \%$ of the feedstock in the Northeast would be trees. However, analysis of the land base, together with our knowledge of expected yields on different land classes, suggested that incorporation of perennial grasses into the feedstock mixture would be required to the distance that crops are hauled. In regions with a narrow corridor of suitable land such as the Pacific Northwest, haul distances as great as 210 miles would be required to supply a singe 2000 -ton per day ethanol conversion facility.

Literature on biogenic hydrocarbon emissions was of particular interest. ESD's Paul Hansen conducted a review of the literature. The data were very incomplete, but they indicated that hardwood species emit isoprenes, some at relatively high levels in comparison to average background forest levels. Sorghum was the only herbaceous crop for which information was available, and it appears to be a monoterpene emitter along with pines and sweetgum. To understand the implications of the average chemical emissions from energy crops, it will be necessary to compare the emissions from energy crops with those expected from other agricultural options in the year 2010. These comparisons should be included in a follow-up effort.

\section{DATA AND INFORMATION HANDLING}

The goal of the Data and Information Handling component is to coordinate, collect, organize, and disseminate information to a wider audience to promote the acceptance of the concept and feasibility of energy crops. The demand for information has increased 
with the emergence of concerns about climate change, greenhouse gases, and USDA setaside policies.

A technical data base containing the results of the SRWC research is available; a similar data base is under development for the herbaceous energy crops. In addition, ORNL staff has developed bibliographic data bases for programmatic-sponsored publications and presentations, related materials, and conversion of woody and herbaceous crops to biofuels. Data management activities included the addition of recently collected data to the technical data base and new materials to the bibliographic data bases. The data bases are used to develop reports and synthesize data and are made available to the public on request.

To identify a target audience for information dissemination activities, the Data and Information Handling staff developed a computerized inventory containing the names of more than 1200 federal, state, and municipal government contacts, regional program managers and staff; research scientists at universities; extension agents; energy crop researchers in academia; members of Congress; and representatives of private industry and trade associations. In addition, the first issue of Energy Crops Fonum, a newsletter devoted to fostering communications among a worldwide research community, policy makers, entrepreneurs, and landowners went to press. The newsletter contained articles about energy crop research, operational experiences with similar crops, environmental concerns, and policy issues, most of which highlighted BFDP activities. Future issues will also feature relevant research and commercial ventures not connected with the program.

\section{INTERNATIONAL ENERGY AGENCY ACTIVTTIES}

IEA biofuels activities are designed primarily for information exchange among participating countries. BFDP gives technical support to DOE for IEA tasks on energy crop production. In 1991 the United States participated in eight such tasks-Energy Forestry Production Systems, Energy Forestry Ecophysiology, Dedicated Agricultural/Herbaceous Crop Systems, Pest/Disease Management, Wood Feedstock Qualities, Tree Ideotypes, Exchange of Genetic Materials, and Joint Trials. Activities included the direct involvement of ESD staff and BFDP subcontractors in cooperative evaluations and joint efforts to summarize and synthesize research results. 


\section{APPENDIX LCONVERSION FACTORS}

\begin{tabular}{|c|c|c|c|}
\hline \multicolumn{4}{|c|}{ ABBREVIATIONS AND EQUIVALENTS } \\
\hline Common Metric Units & & \multicolumn{2}{|c|}{ Power or heat flow rate } \\
\hline Length & & $\begin{array}{l}\text { kilowatt } \\
\text { watt }\end{array}$ & $\begin{array}{l}\mathbf{k W} \\
\mathbf{W}\end{array}$ \\
\hline kilometer & km & & \\
\hline meter & $\mathbf{m}$ & \multicolumn{2}{|c|}{ Metric Unit Prefixes } \\
\hline centimeter & $\mathrm{cm}$ & \multirow{2}{*}{\multicolumn{2}{|c|}{ Prefix symbol factor }} \\
\hline millimeter & mm & & \\
\hline \multirow{2}{*}{\multicolumn{2}{|c|}{ Area }} & exa $\quad E$ & $10^{18}$ \\
\hline & & peta $\mathbf{P}$ & $10^{15}$ \\
\hline square kilometer & $\mathrm{km}^{2}$ & tera $\mathrm{T}$ & $10^{12}$ \\
\hline hectare & ha & giga $\mathbf{G}$ & $10^{9}$ \\
\hline square meter & $\mathbf{m}^{2}$ & mega $\mathbf{M}$ & $10^{6}$ \\
\hline square centimeter & $\mathrm{cm}^{2}$ & kilo $\mathbf{k}$ & $10^{3}$ \\
\hline square millimeter & $\mathrm{mm}^{2}$ & $\begin{array}{ll}\text { hecto } & h \\
\text { deka } & \text { da }\end{array}$ & $\begin{array}{l}10^{2} \\
10^{1}\end{array}$ \\
\hline Volume & & deci d & $10^{-1}$ \\
\hline & & centi c & $10^{-2}$ \\
\hline cubic meter & $\mathbf{m}^{3}$ & milli $\mathbf{m}$ & $10^{-3}$ \\
\hline cubic centimeter & $\mathrm{cm}^{3}$ & micro $\boldsymbol{\mu}$ & $10^{-6}$ \\
\hline liter & $\mathbf{L}$ & & \\
\hline milliliter & $\mathrm{mL}$ & \multicolumn{2}{|c|}{ Metric Equivalents } \\
\hline \multicolumn{2}{|l|}{$\underline{\text { Mass }}$} & \multicolumn{2}{|r|}{$\begin{array}{l}1000 \mathrm{~m} \\
100 \mathrm{~cm}\end{array}$} \\
\hline megagram & Mg & $1 \mathrm{~cm}$ & $10 \mathrm{~mm}$ \\
\hline kilogram & kg & $1 \mathrm{~km}^{2}$ & 100 ha \\
\hline gram & g & $1 \mathrm{Ha}$ & $10,000 \mathrm{~m}^{3}$ \\
\hline milligram & $\mathrm{mg}$ & $1 \mathrm{~m}^{2}$ & $10,000 \mathrm{~cm}^{2}$ \\
\hline & & $1 \mathrm{~cm}^{2}$ & $100 \mathrm{~mm}^{2}$ \\
\hline Density & & \multirow{2}{*}{$\begin{array}{l}1 \mathrm{~m}^{3} \\
1 \text { liter }\end{array}$} & $1000 \mathrm{~L}$ \\
\hline & & & $1000 \mathrm{~cm}^{3}$ \\
\hline \multirow{3}{*}{$\begin{array}{l}\text { kilogram per } \\
\text { cubic meter }\end{array}$} & $\mathrm{kg} / \mathrm{m}^{3}$ & 1 ton & $1000 \mathrm{~kg}$ \\
\hline & & \multirow{2}{*}{$\begin{array}{l}1 \text { ton } \\
1 \text { quintal }\end{array}$} & $1 \mathrm{Mg}$ \\
\hline & & & $100 \mathrm{~kg}$ \\
\hline \multicolumn{2}{|l|}{ Energy, work, or quantity } & $1 \mathrm{~kg}$ & $1000 \mathrm{~g}$ \\
\hline of heat & & $1 \mathrm{~g}$ & $1000 \mathrm{mg}$ \\
\hline gigajoule & GJ & $1 \mathrm{cal}$ & $4.1840 \mathrm{~J}$ \\
\hline megajoule & MJ & $1 \mathrm{cal}$ & $1.5586 \times 10^{-6} \mathrm{hp}-\mathrm{h}$ \\
\hline kilojoule & $\mathrm{kJ}$ & \multirow{3}{*}{$1 \mathrm{cal}$} & $1.1622 \times 10^{-6} \mathrm{kWh}$ \\
\hline joule & $\mathbf{J}$ & & \\
\hline kilowatt-hour & kWh & & \\
\hline
\end{tabular}




\section{English-Metric Conversions}

\section{Length}

Multiply

miles

kilometers

feet

meters

inches

centimeters by

1.6093

0.6214

0.3048

3.2808

2.5400

0.3937

Area

Multiply

square miles

square kilometers

square miler

hectares

square feet

square meters

square inches

square centimeters

square yards

square meters

hectare

acres

Multiply

cords

cubic meters

thousand board feet

cubic meters

cubic feet

cubic meters

cubic inches

cubic centimeters

gallons

liters by

2.5901

0.3861

259.0000

0.0039

0.0929

10.7639

6.4516

0.1550

0.8361

1.1960

2.4710

0.4047

$\underline{\text { Volume }}$

by

3.6246

0.2759

2.3598

0.4238

0.0283

35.3145

16.3872

0.0610

3.7853

0.2642
To obtain

kilometers

miles

meters

feet

centimeters

inches

To obtain

square kilometers square miles hectares

square miles square meters square feet square centimeters square inches square meters square yards acres

hectares

To obtain

cubic meters

cords

cubic meters

thousand board $\mathrm{ft}$

cubic meters

cubic feet

cubic centimeters

cubic inches

liters

gallons 
$\underline{\text { Mass }}$

Multiply

grams
pounds
kilograms
tons $(2000 \mathrm{lb})$
kilograms
tons $(2000 \mathrm{lb})$
tonne $(\mathrm{Mg})$

Multiply

pounds per

cubic font

kilograms per cubic meter

pounds per

cord

kilograms per

cubic meter

tons per

cord

tersine per

cubic meter

Multiply

calories

joules

British thermal units

(Btu or MBtu)

kilojoules (or GJ)

(Btu or MBtu)

horsepower-hours

kilowatt-hours

Btu

kilogram calories

$\mathrm{kWh}$ by

28.3495

0.0353

0.4536

2.2046

907.1940

0.0011

0.9072

1.1023

Density

by

16.0184

0.0624

0.1251

7.9910

0.2503

3.9954

Energy

by

4.1900

0.2387

1.0559

0.9470

0.7457

1.3410

0.2520

3.9680
To obtain

grams

ounces

kilograms

pounds

kilograms

ton (2000 lb)

tonne (Mg)

tons $(2000 \mathrm{lb})$

To obtain

kilograms per cubic meter

pounds per

cubic foot

kilograms per cubic meter

pounds per cord

tonne per

cubic meter

tons per

cord

To obtain

joules

calories

kilojoules

(or GJ)

British thermal

units

kilowatt-hours

horsepower-hours

kilogram calories

Btu

Btu 
Power

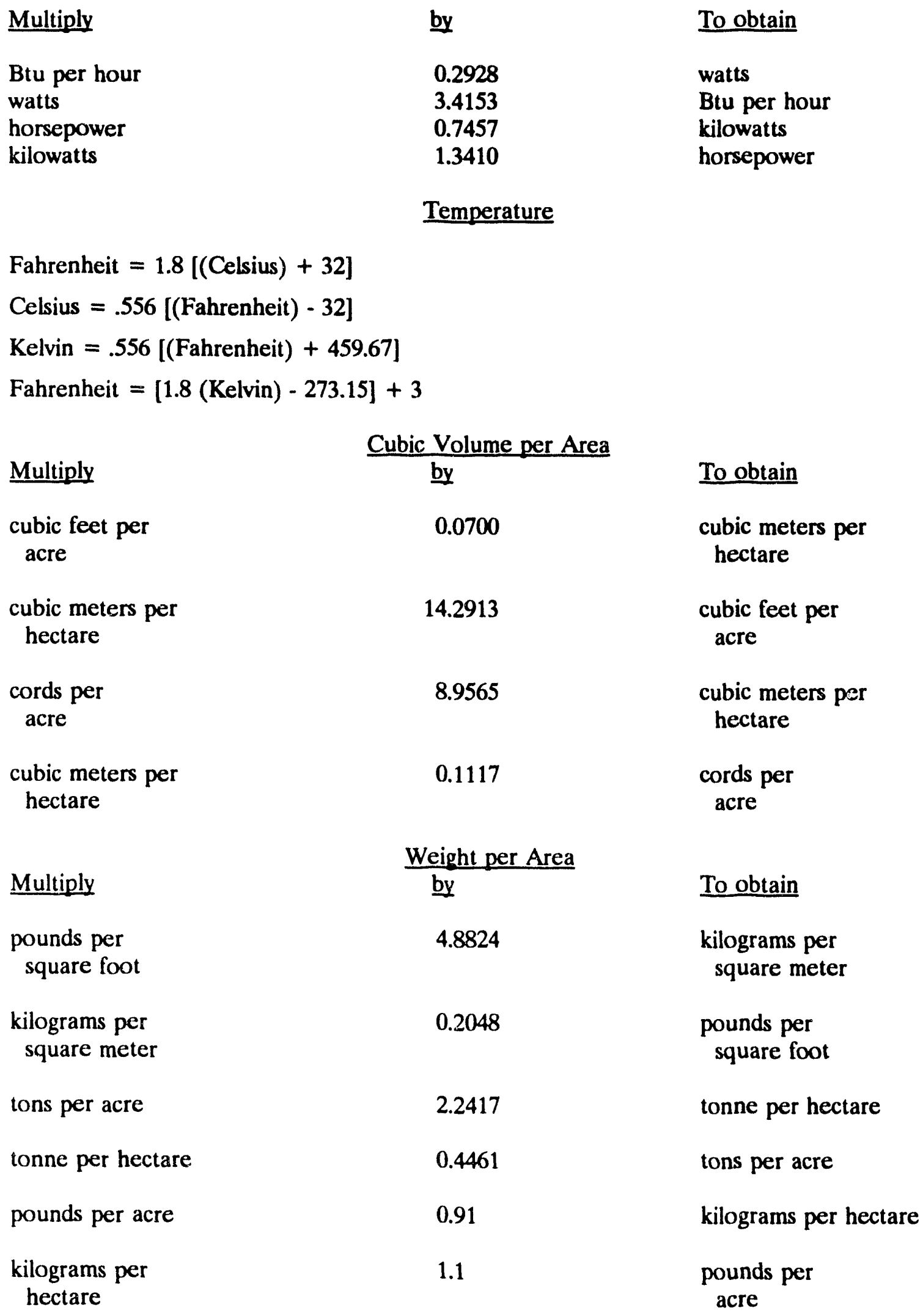




\section{Costs}

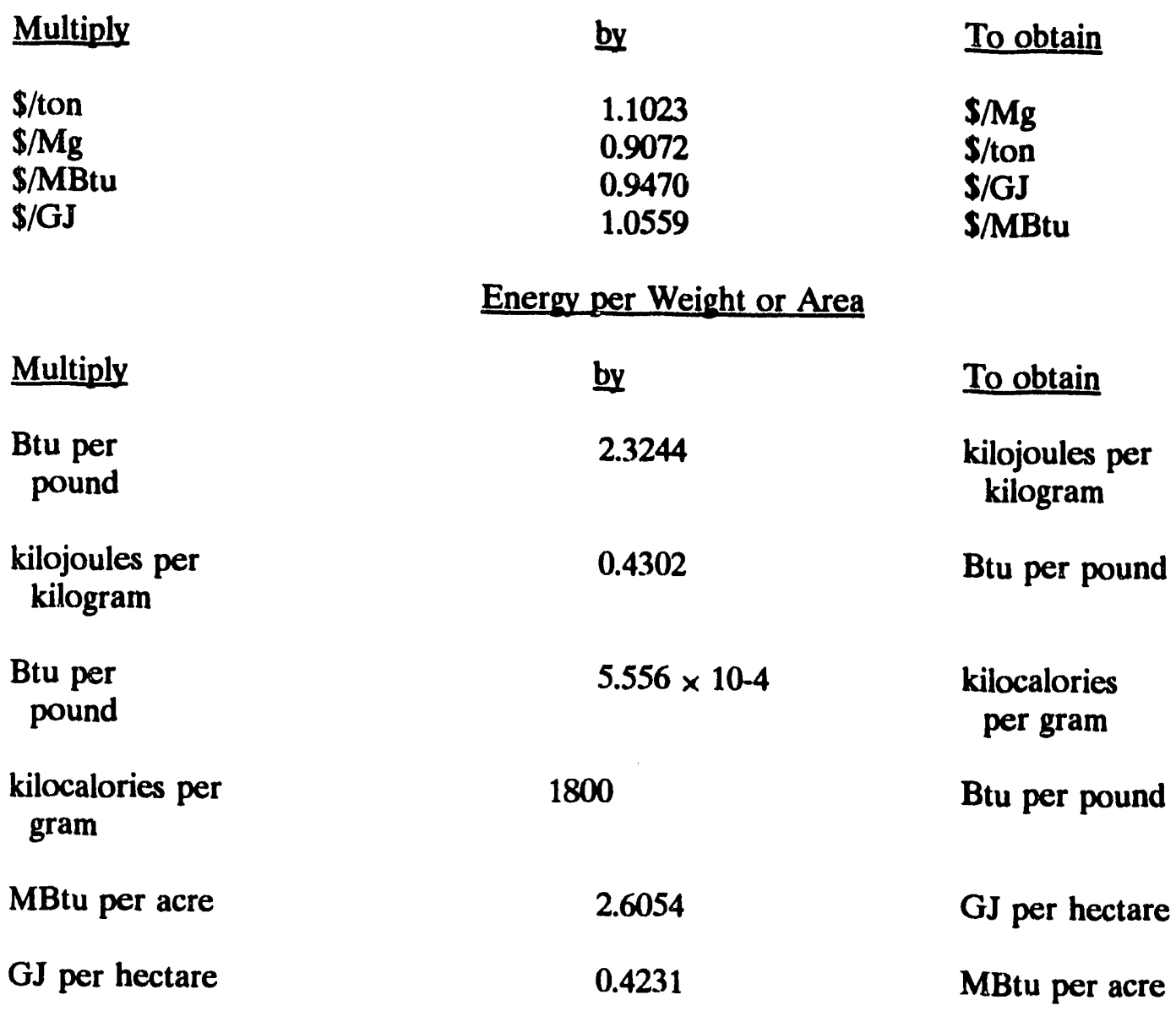

\section{Areas and Radii of Circular Plots}

$\begin{array}{lccccr}\begin{array}{l}\text { Plot size } \\ \text { in acres }\end{array} & \begin{array}{c}\text { Area in } \\ \text { ha }\end{array} & \begin{array}{c}\text { Radius } \\ \mathrm{ft}\end{array} & \begin{array}{c}\text { Radius } \\ \mathrm{m}\end{array} & \begin{array}{c}\text { Area in } \\ \mathrm{ft}^{2}\end{array} & \begin{array}{c}\text { Area in } \\ \mathrm{m}^{2}\end{array} \\ 1 / 10 & 0.0405 & 37.2365 & 11.3497 & 4356 & 404.67 \\ 1 / 5 & 0.0809 & 52.6604 & 16.0509 & 8712 & 809.34 \\ 1 / 4 & 0.1012 & 58.8761 & 17.9454 & 10890 & 1011.68 \\ 1 / 2 & 0.2024 & 83.2634 & 25.3787 & 21780 & 2023.26 \\ 1 & 0.4047 & 117.752 & 35.8909 & 43560 & 046.72\end{array}$

Diameter at breast height $(\mathrm{dhb})=4.5 \mathrm{ft}$ aboveground $=1.372 \mathrm{~m}$ aboveground 


\section{Standard U.S. Fuel Energy Values}

Coal: Anthracite: High heat value $(\mathrm{HHV})=12,700 \mathrm{Btu} / \mathrm{b}$ or $29,540 \mathrm{~kJ} / \mathrm{kg}$ $=25.4 \mathrm{MBtu} / \mathrm{ton}(2000 \mathrm{lb})$ or $29.54 \mathrm{GJ} / \mathrm{Mg}$

Coal: Bituminous: $\mathrm{HHV}=11,750 \mathrm{Btu} / \mathrm{lb}$ or $27,330 \mathrm{~kJ} / \mathrm{kg}$ $=23.5 \mathrm{MBtu} /$ ton or $27.33 \mathrm{GJ} / \mathrm{Mg}$

Coal: Lignite: $\mathrm{HHV}=11,400 \mathrm{Btu} / \mathrm{lb}$ or $26,515 \mathrm{~kJ} / \mathrm{kg}$ $=22.8 \mathrm{MBtu} /$ ton or $26.515 \mathrm{GJ} / \mathrm{Mg}$

Crude oil: $\mathrm{HHV}=18,100 \mathrm{Btu} / \mathrm{lb}$ or $42,100 \mathrm{~kJ} / \mathrm{kg}=138,100 \mathrm{Btu} / \mathrm{gal}$ $=36.2 \mathrm{MBtu} /$ ton or $42.1 \mathrm{GJ} / \mathrm{Mg}$ also $5.8 \mathrm{MBtu} / \mathrm{barrel}(42 \mathrm{gal})$

Natural gas (dry): HHV at $24,700 \mathrm{Btu} / \mathrm{lb}$ or $57,450 \mathrm{~kJ} / \mathrm{kg}=1021 \mathrm{Btu} / \mathrm{ft} 3$ $=49.4 \mathrm{MBtu} /$ ton or $57.45 \mathrm{GJ} / \mathrm{Mg}$

Wood (dry) at $8,500 \mathrm{Btu} / \mathrm{bb}^{*}$ or $19,805 \mathrm{~kJ} / \mathrm{kg}$ $=17.0 \mathrm{MBtu} /$ ton or $19.805 \mathrm{GJ} / \mathrm{Mg}$

*Short-rotation woody crops may vary from 6000 to $8600 \mathrm{Btu} / \mathrm{lb}$

\section{Useful Equivalents for Energy Comparisons}

1 dry ton of wood at $8,500 \mathrm{Btu} / \mathrm{lb}$ has the approximate energy value of the following:

0.72 tons of bituminous coal, 2.93 barrels of average-weight crude oil, $16,642 \mathrm{ft}^{3}$ of natural gas, and $4,981 \mathrm{kWh}$ of electricity.

1 Quad = 1 quadrillion Btu or $1 \times 1015$ Btu $=1.0559 \times 1018$ joules or 1 exajoule 


\section{APPENDIX I-COMMON AND LATIN NAMES OF WOODY SPECIES}

American sycamore

Autumn olive

Balsam poplar

Black cottonwood

Black locust

Black poplar

Douglas-fir

Eastern cottonwood

Eucalyptus

Eucalyptus

European alder

European white birch

Fourwing saltbush

Himalayan balsam poplar

Japanese poplar

Honey locust

Leucaena

Loblolly pine

Mesquite

Monterey pine

(none)

Northern red oak

Quaking aspen

Red alder

Silver maple

Sweetgum

White ash
Platanus occidentalis

Elaeagnus umbellata

Populus balsamifera

Populus trichocarpa

Robinia pseudoacacia

Populus nigra

Pseudotsuga menziesii

Populus deltoides

Eucalyptus grandis

Eucalyptus saligna

Alnus glutinosa

Betula pendula

Atriplex canescens

Populus tristes

Populus maximowiczii

Glenditsia triancanthus

Leucaene retusa

Pinus taeda

Prosopis alba

Pinus radiata

Populus lasiocarpa

Quercus rubra

Populus tremuloides

Alnus rubra

Acer saccharinum

Liquidambar styraciflua

Fraxinus americana 
ORNL-6742

\section{INTERNAL DISTRIBUTION}

1. L. D. Bates

2. R. S. Carlsmith

3. J. B. Cannon

4-23. J. H. Cushman

24-43. A. R. Ehrenshaft

44. D. E. Fowler

45. W. Fulkerson

46. C. W. Gehrs

47. R. L. Graham

48. S. G. Hildebrand

49. P. Kanciruk

50. R. Lee

51. S. B. McLaughlin

52-71. W. A. McNabb

72. R. D. Perlack

73-92. J. W. Ranney
93. D. E. Reichle

94. F. E. Sharples

95. R. B. Shelton

96. D. S. Shriner

97. S. H. Stow

98. T. Tschaplinski

99. A. Turhollow

100. R. I. Van Hook

101-120. L. L. Wright

121. Central Research Library

122-137. ESD Library

138-139. Laboratory Records Dept

140. Laboratory Records

141. ORNL Patent Section

142. ORNL Y-12 Technical Library

\section{EXTERNAL DISTRIBUTION}

143. C. S. Accola, Iowa State University, 1496 Agronomy Hall, Ames, IA 50011

144. J. Allsup, U.S. Dept. of Energy, Office of Alternative Fuels, Forrestal Building, 1000 Independence Ave., SW, Washington, DC 20585

145. I. C. Anderson, Iowa State University, Dept. of Agronomy, Ames, IA 50011

146. P. C. Badger, SE Regional Biomass Energy Program, 435 Chemical Engr. Building, Muscle Shoals, AL 35660

147. J. Berning, Electric Power Research Institute, 3412 Hillview Avenue, Palo Alto, CA 94303

148. D. Betters, Colorado State University, Forest \& Wood Sciences, Room 129 Forestry Bldg., Fort Collins, CO 80523

149. M. Bhat, University of Tennessee, PO Box 1071, Knoxville, TN 37901

150. D. Binkley, Colorado State University, Forestry Department, Ft. Collins, CO 80523

151. J. Birk, Electric Power Research Institute, 3412 Hillview Ave, P.O. Box 10412 , Palo Alto, CA 94303

152. P. R. Blankenhorn, Pennsylvania State University, School of Forest Resources, 310 Forest Research Lab, University Park, PA 16802

153. A. A. Boe, South Dakota State University, Dept. of Plant Science, Brooking, SD 57007

154. B. Bongarten, University of Georgia, School of Forest Resources, Athens, GA 30602

155. D. Boron, Advanced Industrial Concepts, U.S. Department of Energy, 1000 Independence Ave, SW, CE-232, Washington, DC 20585

156. T. Bradshaw, University of Washington, Dept. of Biochemistry SJ-70, Seattle, WA 98195 
157. D. I. Bransby, Auburn University, Dept. of Agronomy \& Soils, 202 Funchess Hall, Auburn, AL 36849-4109

158. D. R. Buxton, Iowa State University, Agricultural Research Service, 1577 Agronomy Hall, Ames, IA 50011

159. I. T. Cailson, Iowa State University, Dept. of Agronomy, Ames, IA 50011-1010

160. A. Chesnes, Deputy Assistant Secretary for Transjiortation Technologies, U.S. Department of Energy, 1000 Independence Ave, SW, MS CE-30, Washington, DC 20585

161. H. Chum, National Renewable Energy Laboratory, 1617 Cole Blvd., Goldon, CO 80401-3393

162. D. P. Christian, Dept of Biology, Univ of Minnesota, 10 University Drive, Duluth, MN 55812

163. K. Clay, Indiana University, Department of Biology, 1575 Linden Drive, Bloomington, IN 47405

164. M. Collins, University of Kentucky, Dept. of Agronomy, N-122 Ag. Sci. Bldg. North, Lexington, KY 40546-0091

165. B. Conger, University of Tennessee, Dept. of Plant and Soil Science, Knoxville, TN 37901-1071

166. R. Conway, U.S. Department of Agriculture, Office of Energy, OE, RM 144E, Admin Bldg, Washington, DC 20250

167. J. H. Cook, National Audubon Society, Scully Science Ctr, 550 South Bay Avenue, Islip, NY 11751

168. J. S. Cundiff, Virginia Tech, Dept of Agricultural Enginering, Blacksburg, VA 24061-0303

169. W. L. Daniels, Virginia Tech, Dept. of Agronomy, Blacksburg, VA 24061

170. D. H. Dawson, 3015 S. River Road., P.O. Box 1321, Rhinelander, WI 54501

171. D. S. DeBell, USDA Forest Service, Forestry Sciences Laboratory, 3625 93rd Avenue, SW, Olympia, WA 98502

172. J.Demetrops, Director, State Energy Programs, U.S. Department of Energy, 1000 Independence Ave, SW, CE-522, Washington, DC 20585

173. D. I. Dickmann, Michigan State University, Dept. of Forestry, 125 Natural Resources, East Lansing, MI 48824-1222

174. B. English, University of Tennessee, Dept Agric Economics \& Rural Sociology, P.O. Box 1071, Knoxville, TN 37901-1071

175. J. E. Ferrell, U.S. Dept. of Energy, Biofuels Systems Division, CE 331 Forrestal Bldg., Washington, DC 20545

176. P. Fox, Bonneville Power Adminsitration, P.O. Box 3621, Routing EPG, Portland, OR 97208

177. J. F. Franklin, Bloedel Professor of Ecosystem Analysis, College of Forest Resources, University of Washington, Anderson Hall (AR-10), Seattle, WA 98195

178. B. Gambles, University of Toronto, Faculty of Forestry, 33 Willcocks St., Toronto, M5S 3B3

179. E. E. Gavett, Ayricultural Economist, 2608 Bowling Green Drive, Vienna, VA 22180

180. S. Gronich, U.S. Department of Energy, CE-132, 5H-059, Forrestal Building, 1000 Independence Ave., SW, Washington, DC 20585 
181. T. Gross, U.S. Department of Energy, Office of Transportation Technology, 1000 Independence Ave., S.W., Washington, D.C. 20585

182. B. Haissig, USDA Forest Service, North Central Forest Exp. Station, P.O. Box 898, Rhinelander, WI 54501

183. R. B. Hall, Iowa State University, Forestry Dept., 251 Bessey Hall, Ames, IA 50011

184. E. A. Hansen, U.S. Forest Service, Forestry Sciences Laboratory, 1831 Highway 169 East, Grand Rapids, MN 55744

185. J. M. Hanowski, Center for Water and Environment/NRRI, University of Minnesota, 5013 Miller Trunk Highway, Duluth, MN 55811

186. L. Harris, USDA Cooperative State Research Service, Aerospace Bldg., Rm. 329N, Washington, DC 20250-2200

187. M. Harris, U.S. Department of Energy, P. O. Box 2008, Oak Ridge, TN 378316269

188. R. C. Harriss, Institute for the Study of Earth, Oceans, and Space, Science and Engineering Research Building, University of New Hampshire, Durham, NH 03824

189. W. Hart, Iowa State University, Dept. of Entomology, 403 Science II, Ames, IA 50011-3222

190. J. Hatfield, USDA/ARS, National Soil Tilth Lab, 2150 Pammel Drive, Ames, IA 50011

191. P. E. Heilman, Washington State University, W. Washington Res. \& Extension Center, Puyallup, WA 98371

192. T. Hinckley, University of Washington, College of Forest Resources, Seattle, WA 98195

193. N. Hinman, National Renewable Energy Laboratory, 1617 Cole Boulevard, Golden, CO 80401

194. W. Hoffman, National Audubon Society, 115 Indian Mound Trail, Tavernier, FL 33070

195. J. G. Isebrands, USDA Forest Service, Forestry Sciences Laboratory, P.O. Box 898, Rhinelander, WI 54501

196. W. Johnson, University of Minnesota, Dowell Hall, Crookston, MN 56716

197. G. Y. Jordy, Director, Office of Program Analysis, Office of Energy Research, ER-30, G-226, U.S. Department of Energy, Washington, DC 20545

198. P. Kormanik, Institute of Tree Root Biology, Forest Sciences Lab, Carlton Street, Athens, GA 30602

199. F. J. Kuzel, Great Lakes Regional Biomass Energy Prg, Council of Great Lakes Governors, 35 E. Wacker Drive, Suite 1850, Chicago, IL 60601

200. S. B. Land, Jr., Mississippi State University, Dept. of Forestry, P.O. Drawer FR, 900 America's Center Bldg., Mississippi State, MS 39762

201. H. L. Lane, U.S. Dept. of Enrgy, Office Conservation \& Renewable Energy, Office of State and Local Programs, Washington, DC 20585

202. P. A. Layton, Scott Paper Worldwide, Scott Plaza III, Philadelphia, PA 19113

203. S. McNabb, Iowa State University, Dept. of Forestry, 251 Bessey Hall, Ames, IA 50011

204. S. Merkle, University of Georgia, School of Forest Resources, Athens, GA 30602 
205. D. W. Meyer, North Dakota State University, Crop and Weed Sciences Department, P. O. Box 5051, Fargo, ND 58105-5051

206. R. Moorer, U.S. Dept. of Energy, Biofuels System Division, CE-341, 1000 Independence Ave., Washington, DC 20585

207. W. Murphey, USDA-CSRS, Rm. 329 M Aerospace Center, 901 M Street, S.W., Washington, DC 20250-2200

208. G. J. Niemi, University of Minnesota, Center for Water and the Environment/, NRRI, 5013 Miller Trunk Highway, Duluth, MN 55811

209. D. Netzer, USDA Forest Service, North Central Forest Exp. Station, Forestry Sciences Laboratory, P.O. Box 898, Rhinelander, WI 54501

210. R. H. Olsen, Professor, Microbiology and Immunology Department, University of Michigan, Medical Science Building II, \#5605, 1301 East Catherine Street, Ann Arbor, MI 48109-0620

211. R. P. Overend, National Renewable Energy Laboratory, Fuels \& Chemicals Research \& Engr. Div., 1617 Cole Blvd., Golden, CO 80401-3393

212. D. J. Parrish, Viginia Tech, Dept. of Agronomy, Blacksburg, VA 24061

213. A. Patrinos, Director, Environmental Sciences Division, Office of Health and Environmental Resesarch, ER-74, U.S. Department of Energy, Washington, DC 20585

214. J. Peterson, NYSERDA, Agency Bldg \#2, Empire State Plaza, Albany, NY 11223

215. C. S. Prakash, Tuskegee University, School of Agriculture, Milbank Hall, Tuskegee, AL 36088

216. J. Preece, Southern Illinois University, Dept. of Plant \& Soil Science, Carbondale, IL 62901

217. K. Pregitzer, Michigan State University, Dept. of Forestry, 111 Natural Resources Building, East Lansing, MI 48824-1222

218. D. Rice, James Rivers Corp., 79114 Collins Road, Box 3211, Clatskanie, OR 97216

219. R. A. Samson, REAP-Canada, Box 125 Glenaladale House, Ste-Anne-DeBellevue, Quebec, H9X 1CO

220. M. A. Sanderson, The Texas A\&M University, Texas Agricultural Experiment Station, Route 2, Box 00, Stephenville, TX 76401

221. L. Schilling, U.S. Department of Energy, Improved Energy Productivity, 1000 Independence Ave, SW, Washington, DC 20585

222. K. R. Schubert, University of Oklahoma, Dept. of Botany \& Microbiology, 770 Van Vleet Oval Rm. 135, Norman, OK 73019-0245

223. S. Sladden, Auburn University, 202 Funchess Hall, Auburn, AL 36849

224. D. A. Sleper, University of Missouri, Dept. of Agronomy, 210 Waters Hall, Columbia, MO 65211

225. R. F. Stettler, University of Washington, College of Forest Resources, Seattle, WA 98195

226. C. H. Strauss, Pennsylvania State University, School of Forest Resources, University Park, PA 16802

227. S. Strobl, Ontatio Ministry of Natural Resources, Fast Forests, P. O. Box 605, Brockville, ONT K6V 5 Y8

228. C. M. Taliaferro, Oklahoma State University, 481 Agriculture Hall, Department of Agronomy, Stillwater, OK 74078 
229. C. Tauer, Oklahoma State University, 012 S. Agriculture Hall, Stillwater, OK 74078

230. J. H. Turnbull, Pacific Gas \& Electric Company, 3400 Crow Canyon Road, San Ramon, CA 94583

231. K. Vogel, University of Nebraska, USDA-ARS, 332 Keim Hall, Lincoln, NE 68583-0910

232. M. Voorhies, U.S. Department of Energy, Regional Biomass Program, CE-522 Forrestal Building, 1000 Independence Ave, SW, Washington, DC 20585

233. D. K Walter, Director, Ofice of Waste Reduction Technologies, Industrial Technologies, U.S. Department of Energy, 1000 Independence Ave, SW, CE231, Washington, DC 20585

234. E. H. White, State University of New York, College of Environ. Sci. \& Forestry, Syracuse Campus, Syracuse, NY 13210

235. D. Wiley, Director, Improved Energy Productivity Division, Industrial Technologies, U.S. Department of Energy, 1000 Independence Ave, SW, CE-231, Washington, DC 20585

236. A. Wiselogel, National Renewable Energy Laboratory, 1617 Cole Blvd., Golden, CO 80401

237. F. J. Wobber, Environmental Sciences Division, Office of Health and Environmental Research, ER-74, U.S. Department of Energy, Washington, DC 20585

238. D. D Wolf, Virginia Tech, Dept. of Agronomy, Blacksburg, VA 24061

239. Office of Assistant Manager for Energy Research and Development, U.S. Department of Energy Field Office, P.O. Box 2001, Oak Ridge, TN 37831-8600

240-241. Office of Scientific and Technical Information, P.O. Box 62, Oak Ridge, TN 37831 
DATE

FILMED

$3 / 16 / 93$ 

$=$ 